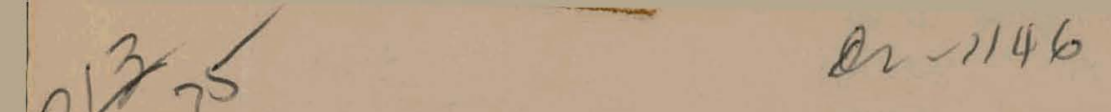

RFP-21 58

RFP-2158

December 31, 1974

\title{
URANIUM-NIOBIUM-ZIRCONIUM ALLOYS:
}

\section{ANNOTATED BIBLIOGRAPHY}

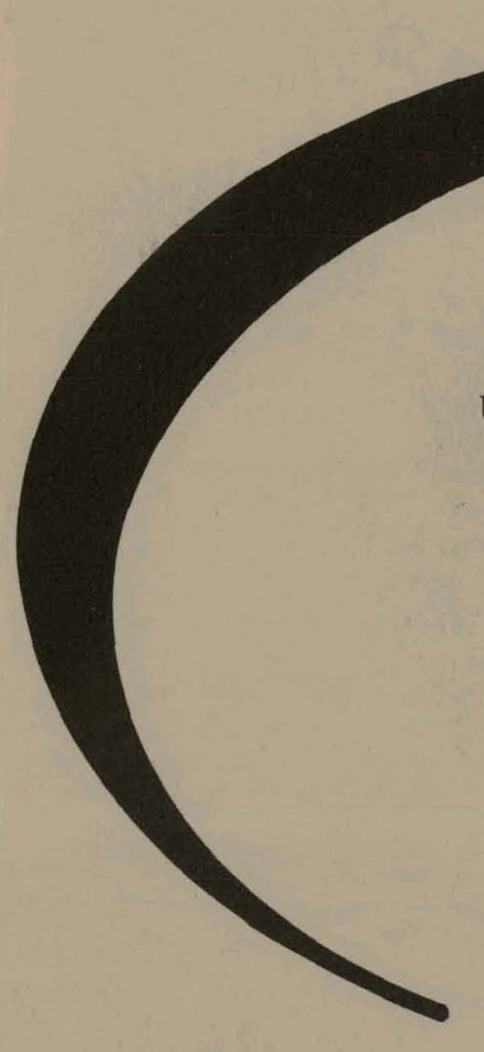

\author{
Ross J. Jackson \\ Patricia A. Kneale \\ U.S. ATOMIC ENERGY COMMISSION \\ CONTRACT AT(29-1)-1106
}




\section{DISCLAIMER}

This report was prepared as an account of work sponsored by an agency of the United States Government. Neither the United States Government nor any agency Thereof, nor any of their employees, makes any warranty, express or implied, or assumes any legal liability or responsibility for the accuracy, completeness, or usefulness of any information, apparatus, product, or process disclosed, or represents that its use would not infringe privately owned rights. Reference herein to any specific commercial product, process, or service by trade name, trademark, manufacturer, or otherwise does not necessarily constitute or imply its endorsement, recommendation, or favoring by the United States Government or any agency thereof. The views and opinions of authors expressed herein do not necessarily state or reflect those of the United States Government or any agency thereof. 


\section{DISCLAIMER}

Portions of this document may be illegible in electronic image products. Images are produced from the best available original document. 


\section{LEGAL NOTICE}

This report was prepared as an account of work sponsored by the United States Government. Neither the United States nor the United States Atomic Energy Commission, nor any of their employees, nor any of their contractors, subcontractors, or their employees, makes any warranty, expressed or implied, or assumes any legal liability or responsibility for the accuracy, completeness or usefulness of any information, apparatus, product or process disclosed, or represents that its use would not infringe privately owned rights.

Printed in the United States of America Available from the

National Technical Information Service

U. S. Department of Commerce Springfield, Virginia 22151

Price: Printed Copy $\$ 4.00$ Microfiche $\$ 2.25$ 


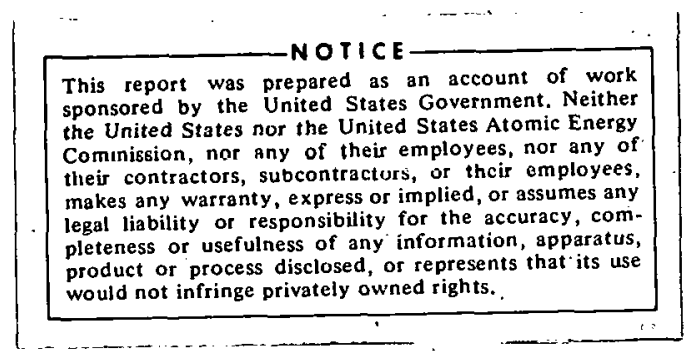

\section{URANIUM-NIOBIUM-ZIRCONIUM ALLOYS:}

\section{ANNOTATED BIBLIOGRAPHY}

Part I. Journal Articles, Formal Reports, and Patents.

Part II. Progress Reports and Newsletters.

Ross J. Jackson

Patricia A. Kneale

Research and Development

PHYSICAL METALLURGY GROUP

SURJECT DESCRIPTORS

Bibliographies

Uranium Base Alloys

Uranium Alloys

Niobium Alloys

Zirconium Alloys

Ternary Alloy Systems

Alloy Systems

Mulberry

Chemical Properties

Mechanical Properties

Physical Properties

Fuel Elements

DOW CHEMICAL U:S.A.

ROCKY FLATS DIVISION

P. O. BOX 888

GOLDEN, COLORADO 80401

Prepared under Contract AT(29-1)-1106

for the

Albuquerque Operations Office

U. S: Atomic Energy Commission 
RFP-21 58 


\section{CONTENTS}

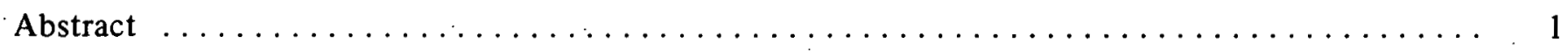

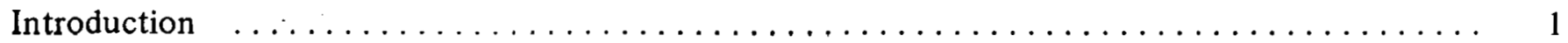

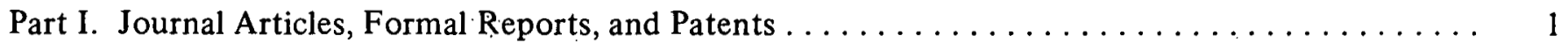

A. Literature and Property Reviews $\ldots \ldots \ldots \ldots \ldots \ldots \ldots \ldots \ldots \ldots \ldots \ldots \ldots \ldots \ldots$

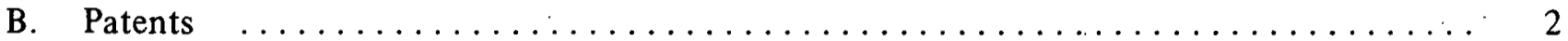

C. Alloy Preparation, Melting, and Casting $\ldots \ldots \ldots \ldots \ldots \ldots \ldots \ldots \ldots \ldots \ldots \ldots \ldots \ldots \ldots \ldots \ldots$

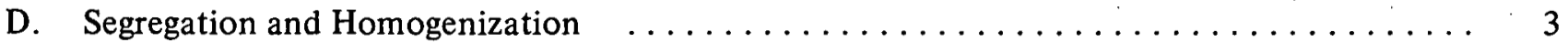

E: Fabrication, Machining, and Joining $\ldots \ldots \ldots \ldots \ldots \ldots \ldots \ldots \ldots \ldots \ldots \ldots \ldots \ldots \ldots \ldots \ldots$

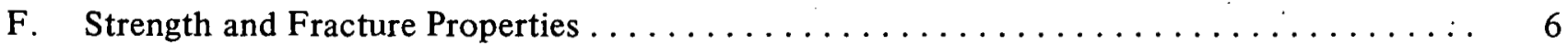

G. Shape Stability $\ldots \ldots \ldots \ldots \ldots \ldots \ldots \ldots \ldots \ldots \ldots \ldots \ldots \ldots \ldots \ldots \ldots$

H. Chemical Dissolution, Separation, and Reprocessing $\ldots \ldots \ldots \ldots \ldots \ldots \ldots \ldots \ldots \ldots \ldots$

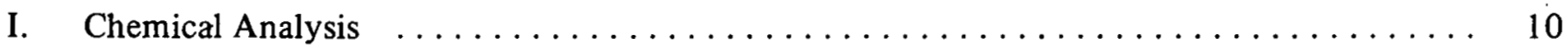

J. Corrosion and Oxidation $\ldots \ldots \ldots \ldots \ldots \ldots \ldots \ldots \ldots \ldots \ldots \ldots \ldots \ldots \ldots$

K. Ignition and Explosive Properties $\ldots \ldots \ldots \ldots \ldots \ldots \ldots \ldots \ldots \ldots \ldots \ldots \ldots \ldots \ldots \ldots \ldots \ldots \ldots . .$.

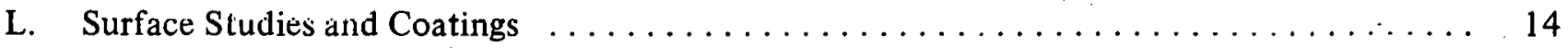

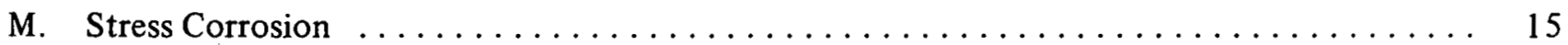

N. Metallographic Techniques and Microstructures ..................... 19

O. Inclusion and Impurity Effects (Hydrogen) $\ldots \ldots \ldots \ldots \ldots \ldots \ldots \ldots \ldots \ldots \ldots \ldots \ldots \ldots \ldots$

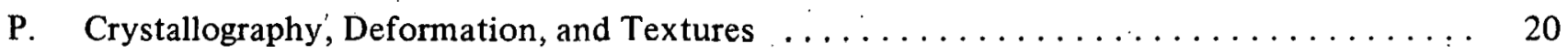

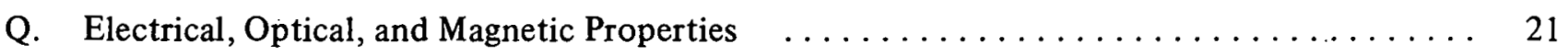

R. Thermal, Dimensional, and Thermodynamic Properties $\ldots \ldots \ldots \ldots \ldots \ldots \ldots \ldots \ldots$

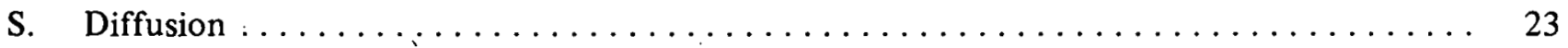

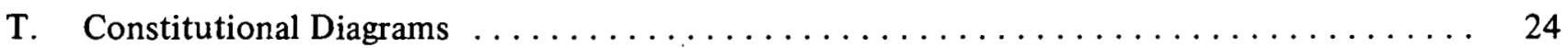

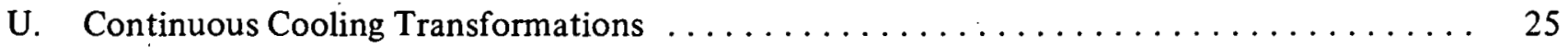

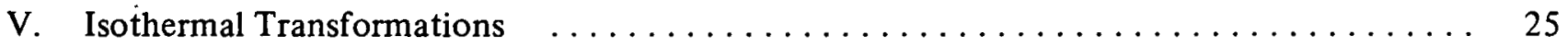

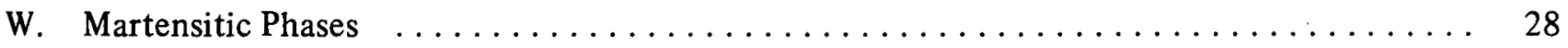

X. Irradiation Effects and Nuclear Properties $\ldots \ldots \ldots \ldots \ldots \ldots \ldots \ldots \ldots \ldots \ldots$

Y. Fuel Element Applications and Properties $\ldots \ldots \ldots \ldots \ldots \ldots \ldots \ldots \ldots \ldots \ldots \ldots$

Part II. Progress Reports and Newsletters $\ldots \ldots \ldots \ldots \ldots \ldots \ldots \ldots \ldots \ldots \ldots \ldots \ldots \ldots \ldots \ldots$

ZA. Ames Laboratory, Ames, Iowa $\ldots \ldots \ldots \ldots \ldots \ldots \ldots \ldots \ldots \ldots \ldots \ldots \ldots \ldots \ldots \ldots$

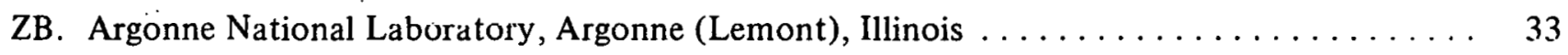


RFP-2158

ZC. Battelle Memorial Institute, Columbus, Ohio $\ldots \ldots \ldots \ldots \ldots \ldots \ldots \ldots \ldots \ldots \ldots \ldots$

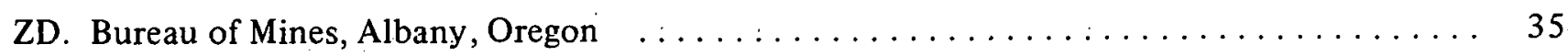

ZE. University of Chicago, Chicago, Illinois $\ldots \ldots \ldots \ldots \ldots \ldots \ldots \ldots \ldots \ldots \ldots \ldots \ldots \ldots \ldots \ldots$

ZF. Division of Research, U.S. Atomic Energy Commission, Washington, D. C. . . . . . 35

ZG. Fuel and Fertile Materials, U.S. Atomic Energy Commission, Washington, D. C. . . . . . 36

ZH. National Lead Company of Ohio, Cincinnati, Ohio $\ldots \ldots \ldots \ldots \ldots \ldots \ldots \ldots \ldots \ldots$

ZI. Oak Ridge National Laboratory, Oak Ridge, Tennessee $\ldots \ldots \ldots \ldots \ldots \ldots \ldots \ldots \ldots \ldots$

ZJ. Westinghouse Electric Corporation, Pittsburgh, Pennsylvania $\ldots \ldots \ldots \ldots \ldots \ldots \ldots \ldots$

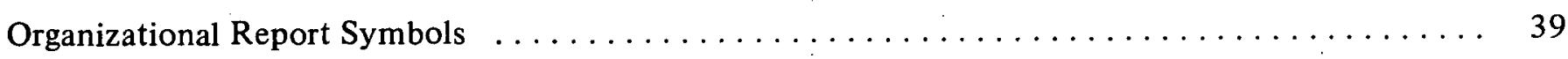

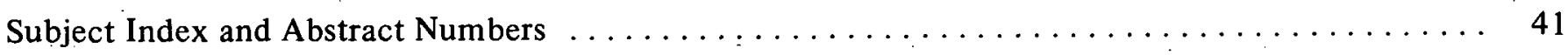

Author Index and Abstract Numbers $\ldots \ldots \ldots \ldots \ldots \ldots \ldots \ldots \ldots \ldots \ldots \ldots \ldots \ldots \ldots$ 


\title{
URANIUM-NIOBIUM-ZIRCONIUM ALLOYS: ANNOTATED BIBLIOGRAPHY
}

\author{
Ross J. Jackson and Patricia A. Kneale
}

\begin{abstract}
An annotated bibliography current as of September 1, 1973, has been prepared on ternary uranium-niobium-zirconium alloys. Most of the materials were obtained from Nuclear Science Abstract entries and to a lesser extent from other sources. Annotations are brief as primary emphasis was placed only on ternary alloys of uranium containing niobium and zirconium.

Arranged in two parts, Part I-Journal Articles, Formal Reports, and Patents contains some 122 references. Part II-Progress Reports and Newsletters contains about 85 references. Included are a subject index, source (organizations) data, and an author index.
\end{abstract}

\section{INTRODUCTION}

A two-part annotated bibliography current as of September 1, 1973, is presented for ternary uranium-niobium-zirconium alloys. Part I contains 122 annotated references and covers Journal Articles, Formal Reports, and Patents. Part II has 85 references and relates to Progress Reports and Newsletters. Most of the references were obtained from Nuclear Science Abstract entries and to a lesser extent from other sources. The annotations accompanying the references do not necessarily represent an entire summary of the referenced work because emphasis was placed only on that portion covering ternary alloys of uranium containing niobium and zirconium.

Each annotated reference is listed only once. An exception refers to the entries under Patents (Section B of Part I), where duplication occurs, however no annotations accompany these references. A subject matter index is provided for overlapping data. An index of organizational (source) symbols is included, and also an author index.

In this report, all abbreviations or symbols used in the original titles are spelled out in full for clarity.
Abbreviations used in the text summaries omit the periods as in weight percent (wt \%); atomic percent (at \%); pages ( $\mathrm{p}$ or $\mathrm{pp}$ ); and with the months as Jan, Feb, etc., but May, June, and July are given in full. Journal names are abbreviated with the use of periods however.

Remarks in brackets are by the author with the exception of titles in English which follow titles given in other languages. Dates entered with a question mark (1900?) indicate the exact date source could not be found.

\section{PART I}

\section{Journal Articles, Formal Reports, and Patents}

In Part I, the references have been categorized according to subject matter. Within a given subject, the references are listed chronologically.

$\underline{\mathbf{A}}$

\section{LITERATURE AND PROPERTY REVIEWS}

\section{A-1}

ADVANCES IN THE PHYSICAL METALLURGY OF URANIUM AND ITS ALLOYS. H. H. Chiswik, A. E. Dwight, L. T. Lloyd, M. V. Nevitt, and S. T. Zegler. Report A/CONF. 15/P/713. 35 p. Prepared for the Second United Nations International Conference on the Peaceful Uses of Atomic Energy, Geneva, Switzerland. 1958.

A general survey is presented of information in the uranium alloy field. Emphasis is centered on alpha uranium-rich alloys (including $\mathrm{U}-\mathrm{Zr}-\mathrm{Nb}$ alloys) of special interest as uranium-base fuel element materials. The properties covered include constitution phase diagrams, metallographic structure, physical and mechanical properties, transformation kinetics, crystallographic structure, 
thermal cycling, and irradiation stability (where pertinent). Correlations between microstructure, heat treatment, and dimensional stability are emphasized. A discussion of the role of alloyingand heat-treatment in improving the dimensional stability and corrosion resistance of uranium is presented, and an evaluation is made of the present status in attaining these objectives.

\section{(}

A-2

PROPERTIES OF MULBERRY. H. D. Weiss. Report UCID=15170. July 28, 1967. 26p.

Described is Mulberry, a metastable gamma-phase $\mathrm{U}-\mathrm{Nb}-\mathrm{Zr}$ alloy. Physical properties are given; mechanical properties are detailed. Metallurgical characteristics are tabulated. 18 references.

A-3

LITERATURE SURVEY ON DILUTE URANIUM ALLOYS FOR SANDIA BOOSTER CONCEPT TO SANDIA CORPORATION. J. M. Fackelmann, A. A. Bauer, and D. P. Moak. Report BMI-X-10264. July 1969. 81p.

Although data on the uranium-molybdenum system are fairly complete, many of the mechanical properties reported may have been affected by uncontrolled stress-corrosion effects which are still not fully understood. The elevated-temperature data on the uraniumniobium alloy are rather incomplete. Detailed studies on the effect of aging and strain rate on mechanical properties are lacking for the uranium-zirconium system. Although limited information suggests some potential for uraniumchromium alloys as a booster fuel, the available property data are extremely limited. A good deal of pertinent research was performed on Mulberry alloy (U-7.5 wt \% Nb-2.5 wt \% Zr), but this ternary alloy is complex and there are still a lot of gaps in the available data. A problem common to all of the metastable gamma alloys is that sufficient attention was not given to transformations that may be occurring during testing at elevated temperature. Hence, many of the reported data on gamma-phase alloys become suspect.
$\underline{\mathbf{B}}$

PATENTS

B-1

TERNARY ALLOYS OF URANIUM, COLUMBIUM, AND ZIRCONIUM. F. G. Foote. British Patent 803,118. Nuclear Eng. 4:284. June 1959. [An annotated reference appears under Y-5.]

B-2

TERNARY ALLOYS OF URANIUM, COLUMBIUM, AND ZIRCONIUM. F. G. Foote (to U.S. Atomic Energy Commission). U.S. Patent 2,947,621. Aug 2, 1960. [An annotated reference appears under $Y-6$.]

B-3

ALLOY MEMBERS SUITABLE FOR USE AS NUCLEAR FUEL ELEMENTS AND PROCESS FOR MAKING THE SAME. (To U.S. Atomic Energy Commission.) British Patent 854,096. Nov 16, 1960. [An annotated reference appears under E-5.]

B-4

DIMENSIONALLY STABLE, CORROSION RESISTANT NUCLEAR FUEL. J. H. Kittel (to U.S. Atomic Energy Commission). U.S. Patent 3,089,768. 1960.

[An annotated reference appears under G-1.]

B-5

DIMENSIONALLY STABLE AND CORROSION RESISTANT NUCLEAR FUEL. (To U.S. A tomic Energy Commission.) French Patent 1,314,903. Dec 3, 1962. Priority date Mar 1, 1961, United States. [An annotated reference appears under G-2.]

$$
\begin{gathered}
\underline{\mathrm{C}} \\
\text { ALLOY PREPARATION, } \\
\text { MELTING, AND CASTING }
\end{gathered}
$$

\section{C-1}

NUCLEAR METALLURGY. VOL. IV. A SYMPOSIUM ON URANIUM AND URANIUM DIOXIDE. IMD Special Report Series No. 4. 
New York, the Metallurgical Society of American Institute of Mining, Metallurgical, and Petroleum Engineers, 1957. 146p.

This volume contains the papers presented at a Symposium on the fabrication of $U$ and the preparation and fabrication of $\mathrm{UO}_{2}$ for fuel element use held at the IMD Fall Meeting, Morrison Hotel, Chicago, Nov 6, 1957.

A paper on "Melting and Casting of Uranium, Zirconium, Niobium Alloys" is included.

\section{C-2}

PREPARATION OF URANIUM ALLOYS BY MELTING. W. B. Haynes and F. R. Lorenz. Report WAPD-PWR-FEm-106. Feb 16, 1956. Declassified Oct 2, 1958. 20p.

Methods of melting uranium and its alloys are examined including vacuum induction melting and consumable and non-consumable electrode arc melting. The equipment and procedures are outlined with the limitations and uses of each method. In addition, the preparation and properties of Al-U, Cr-U, Mo-U, U-Nb, U-Si, and $\mathrm{U}-\mathrm{Zr}$, and $\mathrm{Nb}-\mathrm{U}-\mathrm{Zr}$ alloys are described. Special techniques of agitation during freezing to produce fine castings are listed along with a discussion of the advantages of centrifugal casting.

\section{C-3}

CASTING URANIUM-5 WEIGHT PERCENT ZIRCONIUM-1.5 WEIGHT PERCENT NIOBIUM ALLOYS INTO ZIRCONIUM AND ZIRCALOY -2 CONTAINERS. J. W. Frank and R. E. Macherey. Report ANL-5442. July 1958. 49p.

A series of experimental castings have been made with the object of exploring the proposition that uranium and high uranium alloys could be bonded to zirconium and zirconium alloys by a direct casting method. Unalloyed uranium and uranium alloyed with $5 \mathrm{wt} \% \mathrm{Zr}$ and '1.5 wt $\% \mathrm{Nb}$ have been cast into zirconium and Zircaloy- 2 molds of various shapes and sizes. Castings made in cans of circular cross section were well bonded and sound, provided the molds were outgassed at elevated temperature before use and proper preheating precautions were observed. Molds of rectangular cross sections, however, did not yield as satisfactory results, mainly because of porosity. The asymmetry of this type of mold probably contributed to the lack of success. Good bonds were obtained between uranium and zirconium by casting into graphite molds lined on opposite sides with zirconium plates.

C-4

STUDY OF A HIGH MECHANICAL RESISTANCE URANIUM ALLOY CONTAINING 7.5 PERCENT NIOBIUM AND 2.5 PERCENT ZIRCONIUM (BY WEIGHT). P. Choquet. Report CEA-R-4291. Apr 1972. 135p. (In French.)

A method of manufacturing $U$ alloy ingots containing 7.5 percent $\mathrm{Nb}$ and 2.5 percent $\mathrm{Zr}$ (by weight) using an induction furnace was developed. The crucible and the mold were made using a plasma torch to melt the calcium zirconate and zirconium powders. In the crucible, the load was maintained well agitated for 45 minutes between 1550 and $1650^{\circ} \mathrm{C}$. Casting was carried out at $1600^{\circ} \mathrm{C}$. The solidification must be directed for the best results to be obtained with a $1000^{\circ} \mathrm{C}$ thermal gradient in the mold, the top of the mold being at $1400^{\circ} \mathrm{C}$. Some attempts were made at refusion using an electron bombardment furnace, but the results have still to be verified. Mechanical trials on test rods of the ingot material were conducted after homogenization at $1000^{\circ} \mathrm{C}$ for 8 hours and after the following treatments: quenching in water; quenching in oil; and quenching in water after tempering up to $350^{\circ} \mathrm{C}$. Rupture loads were between 80 and 165 danewtons $/ \mathrm{mm}^{2}$, elastic limits of 0.2 percent were between 40 and 50 danewtons $/ \mathrm{mm}^{2}$, and elongations were between 23 and 0.5 percent.

D

SEGREGATION AND HOMOGENIZATION

D-1

SURVEY OF TERNARY AND QUATERNARY METASTABLE GAMMA-PHASE URANIUM 
ALLOYS. V. W. Storhok, A. A. Bauer, and R. F. Dickerson. Report BMI-1278. July 15, 1958. 38p.

A survey of the effects of ternary and quaternary alloying on the stability and properties of uranium-zirconium, -niobium, and -molybdenum-base gamma-phase alloys was conducted. The effects of ternary and quaternary additions of chromium, molybdenum, niobium, ruthenium, vanadium, and zirconium on transformation kinetics, transformation temperature, hot hardness, and corrosion resistance were investigated. Niobium or molybdenum additions to uranium-zirconiumbase alloys increased thermal stability and hot hardness of the gamma phase and lowered transformation temperatures. These additions also generally resulted in improved corrosion resistance. Zirconium increased the gamma-phase stability in uranium-niobium-base alloys, lowered transformation temperatures, and in some amounts increased hot hardness and improved corrosion resistance: Variable corrosion behavior of the uranium-niobiumzirconium alloys is probably attributable to lack of homogeneity.

\section{$\underline{\mathbf{E}}$}

FABRICATION, MACHINING, AND JOINING

\section{E-1}

\section{THE FABRICATION OF FUEL ELEMENTS} FOR POWER REACTORS. J. F. Schumar (ANL). Report TID-2508. Nuclear Science and Technology 1A:409-444. Dec 1955. 36p.

Methods for the manufacture of $\mathrm{Zr}$-clad $U$ plates and Zircaloy-2-clad U-Nb-Zr alloy plates for water-cooled power reactors are described.

The basic technique consists of enclosing the core in a can of the jacket material to form a composite billet, which is then enclosed in a steel can and hot rolled into a flat plate. Various methods of fabricating the plates, the effect of billet atmosphere on bonding, the advantages of various billet shapes, and corrosion testing and inspection of the plates are discussed. Fuel plates for reactors using high-energy neutrons must have a high surface-to-volume ratio and have adequate corrosion resistance to coolants such as liquid $\mathrm{Na}$. Techniques for roll bonding stainless steel of $\mathrm{Ni}$ to $\mathrm{U}$ with $\mathrm{Ag}$ as the bonding medium have been developed for this type of fuel plate. The fabrication of large numbers of small-dimensional enriched-U fuel components with thin sections can be accomplished by multiple mold centrifugal casting. The casting machine and procedures are described.

\section{E-2}

ZIRCONIUM CLADDING OF URANIUM AND URANIUM ALLOYS BY COEXTRUSION.

A. R. Kaufmann, J. L. Klein, P. Loewenstein, and H. F. Sawyer, (NMI). Report TID-7546, 157-181. Fuel Elements Conference, Paris, France. Nov 18-23, 1957. 25p. (NMI-TJ-8.)

The principles governing the techniques used in the coextrusion of two or more metals are discussed in general, and the application of these principles to the fabrication of zirconiumclad uranium fuel elements having in tegral zirconium end seals is discussed in detail. The extrusion billet consists of a uranium or uranium alloy core surrounded by a zirconium or Zircaloy-2 sleeve and end pieces (cladding); the core and cladding components are enclosed in an evacuated, sealed copper can and extruded. Special precautions to obtain good bonds between core and cladding, uniform cladding, and satisfactory interfaces between core and end seals are described. Specific techniques, component design, billet design, extrusion conditions, and a description of the resultant product obtained (clad rod or tube) are given for the zirconium or Zircaloy-2 cladding of unalloyed uranium, uranium-2\% zirconium, uranium- $10 \%$ molybdenum, uranium- $4 \%$ silicon, and uranium-5\% zirconium- $1.5 \%$ niobium.

\section{E-3}

THE METALLURGY AND FABRICATION OF URANIUM-ALLOY FUEL ELEMENTS. R. W. Dayton (BMI). Report TID-7546, 302-365.

Fuel Elements Conference, Paris, France.

Nov 18-23, 1957. 63p.

Uranium fuel alloys are discussed which have received considerable attention for use in 
power reactors. The alloy types discussed include the so-called "alpha-prime" alloys (containing 3 to $7 \mathrm{wt} \%$ niobium and zirconium), gamma-phase alloys (containing 10 to $20 \mathrm{wt} \%$ molybdenum or niobium), and epsilon-phase alloys (containing $3.8 \mathrm{wt} \%$ silicon or 45 to $80 \mathrm{wt} \%$ zirconium). Each of these alloys has unique characteristics which dictate the methods that are used to process it to fuel elements. These characteristics are discussed, as are the processing methods suitable for each alloy. The fabrication methods discussed are induction and arc melting for alloy preparation and brazing, roll bonding, and pressure bonding for cladding the fuel alloys. The discussion is confined to cladding with zirconium alloys metallurgically bonded. Brief mention is made of end capping by welding. Other fabrication techniques which are not unique are not considered. A summary of basic metallurgical information on the fuel alloys is added to provide background for the discussion of fabrication.

\section{E-4}

ROLL CLADDING URANIUM-ZIRCONIUM AND URANIUM-ZIRCONIUM-NIOBIUM ALLOYS WITH ZIRCALOY-2 FOR PLATETYPE FUEL ELEMENTS. C. H. Bean, R. E. Macherey, and J. R. Lindgren. Report ANL5628. Feb 1958. 288p.

Clad plate-type fuel elements containing U-5 wt \% $\mathrm{Zr}-1.5 \mathrm{wt} . \% \mathrm{Nb}$ alloy cores integrally clad on all surfaces with Zircaloy-2 were developed for the Experimental Boiling Water Reactor (EBWR). These plates were prepared by roll bonding assembled components inside steel jackets at $850^{\circ} \mathrm{C}$ with $80 \%$ reduction in thickness to effect sound diffusion bonds at all component surfaces. To obtain reproducible sound bonds, uranium alloy core and cladding components were clean and free from surface contamination, such as inclusions, oxides, or foreign material; contamination of mating surfaces was avoided during welding operations; all bonding surfaces were sealed to prevent contamination from outgassing of the steel jacket during heating and rolling; billets were designed with a differential thermal expansion allowance for the core relative to the cladding; and all assembled billet components were evacuated and sealed by welding in a vacuum. Integrally roll-bonded end closures were obtained by orienting billet end plugs so that the prior hot-working anisotropy of Zircaloy-2 would increase their lateral spread and facilitate the Zircaloy-2 end to Zircaloy- 2 side bonds during rolling.

Investigations were made of alternate methods of bonding fuel shapes and the use of alternate core alloys in flat plates. Roll bonding in shaped pass rolls, cast bonding the core alloy into Zircaloy- 2 molds, and bonding by coextrusion were all found to be feasible, although no integrally clad specimens were prepared for in-pile testing. Substitution of $\mathrm{U}-\mathrm{Zr}$ binary alloys for the ternary reference alloy in roll-clad plates did not appear promising from corrosion test data, and further development with core alloy substitutions was abandoned. Alterations and additions were made to development facilities needed to fabricate roll-clad plates for the EBWR core. Pilot production of EBWRtype plates proved that the plate cladding process could be adapted to production facilities.

\section{E-5}

\section{ALLOY MEMBERS SUITABLE FOR USE AS} NUCLEAR FUEL ELEMENTS AND PROCESS FOR MAKING THE SAME. (To U.S. Atomic Energy Commission.) British Patent 854,096. Nov 16, 1960.

A uranium alloy exhibiting high resistance to corrosion by high-temperature water and steam and suitable for use as a fuel alloy in pressurized water and other types of reactors can be fabricated. The alloy consists of 3 to $25 \%$ niobium, 1 to $30 \%$ zirconium, and the balance uranium, the total weight of niobium and zirconium not exceeding $40 \%$. The alloy should be in the gamma phase and clad with a zirconium-base alloy containing 0.1 to $2.5 \%$ tin and 0.1 to $2 \%$ of at least one of the elements, iron, niobium, or chromium, and having a thickness $\geqslant 0.009$ inches. A method for producing and fabricating the fuel alloy is presented. A clad fuel alloy made in this way gave only a 1 to 2 vol \% increase at $0.45 \%$ burn-up and $385^{\circ} \mathrm{C}$ in a reactor, as compared with 8 to 10 vol \% increases for U-Nb alloys. Out-of-pile corrosion tests showed that this 
alloy has superior resistance compared with $\mathrm{U}-\mathrm{Nb}$ alloys.

\section{E-6}

\section{ELECTRON BEAM WELDING STUDY ON} URANIUM-NIOBIUM-ZIRCONIUM ALLOY.

Final Report. J. R. McDougal and L. A. Greene. Report MLM-1778. Dec 23, 1970. 17p.

An electron beam welding study was conducted on Mulberry alloy (U-7.5\% Nb-2.5\% Zr). The study was conducted on 0.080 - and 0.250 -inch thick sheet stock. The purpose of the study was to determine what effect the variation of welding parameters would have on weld characteristics in partial penetration welds. The use of a straight beam of electrons or AC deflection resulted in weld spiking and cold shut area in the 0.250-inch thick material. Circle generation drastically reduced the number of weld defects. The 0.080 -inch thick Mulberry welded easily except when AC deflection was used where the amount of weld porosity in the fusion area was high.

\section{E-7}

\section{INDUSTRIAL HYGIENE CONTROL OF A URANIUM SHEAR-SPINNING OPERATION.} F. J. Foster (Philco-Ford Corporation, Newport Beach, California). Amer. Ind. Hyg. Assn.J. 32:786-789. Dec 1971.

Metal shearspinning is one of the oldest of metal-forming processes, dating back to the Egyptian production of copper pots and bowls approximately 3000 years ago. Modern uranium shearspinning is an efficient method of precision metal forming which produces very little airborne contamination. A total of 98 air and wipe samples taken to date have revealed no excessive concentrations. Air samples were collected on Whatman 41 filter paper utilizing Staplex Type TFIA and ICN Model 8000 high-volume air samplers and the MSA Monitaire personal air sampler. The average breathing zone concentration was less than $5 \times 10^{-3}$ microcuries per millilitre. Samples were analyzed for alpha radiation in an alpha scintillation counter. In addition to monitoring of indoor and outdoor air concentrations, the control program plan included special facility design and construction, personnel medical clearance and surveillance, protective clothing, and control of waste products. Intermittent operation of the facility over the past two years has occurred without major incident. It is concluded that the control techniques outlined have been successful.

\section{$\underline{\mathbf{F}}$}

\section{STRENGTH AND FRACTURE PROPERTIES}

\section{F-1}

MECHANICAL PROPERTIES OF URANIUMZIRCONIUM-NIOBIUM ALLOYS. L. I. Gomozov. Stroenie i Svoistva Splavov Urana, Toriya i Tsirkoniya 194-201. Moscow; Gosatomizdat, Russia. 1963.

Heterogeneous $a+\gamma$ phase $\mathrm{U}-\mathrm{Zr}-\mathrm{Nb}$ alloys possess a higher yield strength than binary uranium alloys. The hardness of low-alloyed (up to 5 at \%) U-Zr-Nb system is $180 \mathrm{~kg} / \mathrm{mm}^{2}$ at $20^{\circ} \mathrm{C}, 150 \mathrm{~kg} / \mathrm{mm}^{2}$ at $150^{\circ} \mathrm{C}$, and $45 \mathrm{~kg} / \mathrm{mm}^{2}$ at $500^{\circ} \mathrm{C}$ with ductility $(\delta)$ not less than 2.5 . The hardness of alloys with 12 to 18 at $\% \mathrm{Zr}$ and 4 to 7 at $\% \mathrm{Nb}$, after 24 hours of $500{ }^{\circ} \mathrm{C}$ annealing, was $85 \mathrm{~kg} / \mathrm{mm}^{2}$ and $\delta=6 \%$. For alloys with 10 to 14 at $\% \mathrm{Zr}$ and 16 to $20 \%$ at $\% \mathrm{Nb}$, after $1000 \mathrm{hr}$ annealing the $\sigma_{\mathrm{w}}=100$ $\mathrm{kg} / \mathrm{mm}^{2}$ and $\delta=5 \%$. With 30 to 40 at $\%$ alloying, $\mathrm{Zr}$ at $\%$ ratio to $\mathrm{Nb}$ at $\%=1: 4$ to $1: 5$, the best heat resistance was obtained and ductility was satisfactory at $750^{\circ} \mathrm{C}$.

\section{F-2}

MECHANICAL PROPERTIES OF URANIUMMOLYBDENUM-ZIRCONIUM AND URANIUMZIRCONIUM-NIOBIUM-MOLYBDENUM AT ELEVATED TEMPERATURES. G. N. Bagrov, Yu. S. Virgil'ev, and O. S. Ivanov. Stroenie $i$ Svoistva Splavov Urana, Toriya i Tsirkoniya 206-216. Moscow, Gosatomizdat, Russia. 1963.

Short-period creep-rupture tests of $\gamma$ phase $\mathrm{U}-\mathrm{Zr}-\mathrm{Nb}$-Mo alloys at $750^{\circ} \mathrm{C}$ showed that yield strength increased with increased alloying elements. With a constant $U$ content the yield strength improves with increasing replacement of $\mathrm{Zr}$ by $\mathrm{Nb}$ and $\mathrm{Mo}$. Creep resistance of $\gamma$-phase alloys tested for $100 \mathrm{hr}$ at $750{ }^{\circ} \mathrm{C}$ and $0.25 \mathrm{~kg} / \mathrm{mm}^{2}$ pressure was improved by raising 
the total content of alloying elements of 40 at \%; it was also improved by $\mathrm{Nb}$ and Mo replacement of $\mathrm{Zr}$. Short-period creep-rupture tests at $500^{\circ} \mathrm{C}$ on alloys tempered at $1000^{\circ}$ and annealed at $500^{\circ}$ for 100 and 1000 hours showed the best results with 70 at $\% \mathrm{U}$. Alloy ductility dropped sharply with increased alloying elements and was close to zero with 60 at \% U. An increased amount of alloying at a constant ratio improves the creep resistance of the alloys, especially at 550 and $600^{\circ} \mathrm{C}$.

\section{F-3}

MECHANICAL PROPERTIES OF SOME URANIUM ALLOYS. C. A. W. Peterson and R. R. Vandervoort. Report UCRL-7771. Mar 18, 1964. 6p.

$\mathrm{Mo}, \mathrm{Nb}$, and $\mathrm{Zr}$ were added separately and in combination to $U$ and the properties of the gamma-phase alloys measured at room and elevated temperatures. Mechanical properties of gamma-phase, uranium-base, U-Nb-Zr alloys are included.

\section{F-4}

THE PROPERTIES OF A METASTABLE GAMMA-PHASE URANIUM-BASE ALLOY: URANIUM-7.5 NIOBIUM-2.5 ZIRCONIUM. C. A. W. Peterson and R. R. Vandervoort. Report UCRL-7869. May 13, 1964. 36p.

The uranium-niobium-zirconium ternary system exhibits a series of solid solutions at high temperature. Addition of both niobium and zirconium stabilizes the body-centered-cubic gamma phase to a lower temperature. A study has been made of one particular ternary alloy, the U-7.5 wt \% Nb-2.5 wt \% $\mathrm{Zr}$ composition. The relationship of transformation characteristics of the alloy to its physical and:mechanical properties has been determined. This weldable alloy is concluded to be an excellent material for engineering applications. Tensile yield strengths of 100,000 to $200,000 \mathrm{psi}$ are obtainable, with elongations of $12 \%$ to $4 \%$, respectively, depending on heat treatment.

\section{F-5}

PHYSICAL AND MECHANICAL PROPERTIES OF URANIUM-7.5 WEIGHT PERCENT
NIOBIUM-2.5 WEIGHT PERCENT ZIRCONIUM ALLOY. C. A. W. Peterson and W. E. Elkington. Report UCRL-14724. Feb 17, 1966. 12p.

The physical and mechanical properties of a uranium-7.5 wt \% Nb-2.5 wt \% $\mathrm{Zr}$ alloy aged in the temperature range $150-350^{\circ} \mathrm{C}$ are reported. The mechanical strength of the alloy increased with aging temperature and time within this range. More reproducible mechanical properties were obtained from the heat treatments than previously reported. The tensile yield strength was typically $92,000 \mathrm{psi}$ after a 1 -hour, $150^{\circ} \mathrm{C}$ heat treatment; 215,000 psi after 4 -hour, $350^{\circ} \mathrm{C}$ heat treatment. Elongations for these strength levels were 20 and $3.5 \%$, respectively. Electrondiffraction data show that an ordered structure was developed during aging at $150^{\circ} \mathrm{C}$ for $10^{4}$ minutes. It is believed that the increase in strength which results at this aging temperature is partly due to this ordering of the alloy.

\section{F-6}

MECHANICAL PROPERTIES OF GAMMAPHASE URANIUM-7.5 NIOBIUM-2.5 ZIRCONIUM ALLOY UNDER DYNAMIC LOADING. K. G. Hoge. Report UCRL-14805. Apr 6, 1966. 13p.

The effects of dynamic tension loading on the mechanical properties of gamma-phase U-7.5 wt \% $\mathrm{Nb}-2.5 \mathrm{wt} \% \mathrm{Zr}$ alloy are presented. Test data were taken at temperatures of $23, .200,300$, 400 , and $500^{\circ} \mathrm{C}$, at strain rates varying from $10^{-3}$ to 1600 inches per inch-second. Tensile strength increased moderately with increasing strain rates, but more important was the fact that dynamic loading caused only a slight decrease in ductility. However, the Time, Temperature, Transformation (TTT) curves for this alloy indicate that the gamma phase begins to transform to a cellular structure at temperatures slightly above $300^{\circ} \mathrm{C}$ in only a couple of minutes. At temperatures above $500{ }^{\circ} \mathrm{C}$ it transforms into a pearlitic alpha-plus-gamma-2 structure.

\section{F-7}

DETERMINATION OF THE MODULI OF ELASTICITY AND SHEAR AT TEMPERATURES UP TO $2000^{\circ} \mathrm{C}$ IN VACUUM AND 
INERT GAS ATMOSPHERE. V. A. Bogrov, V. K. Grigorovich, A. N. Kobylkin, and O. S. Ivanov. (Inst. of Metallurgy, Moscow, Russia). Zavod. Lab. 34:994. 1968. (In Russian).

For the determination of the characteristics of elasticity, the radiotechnical resonance method was used. The installation, which permits measurements at frequencies of 20 to 200,000 $\mathrm{GHz}$ at temperatures up to $2000^{\circ} \mathrm{C}$ in vacuum at least $5 \times 10^{-5} \mathrm{~mm} \mathrm{Hg}$, was developed. The modulus of elasticity of the alloy system uranium-zirconium-niobium was measured at temperatures up to $900^{\circ} \mathrm{C}$ and the concentration dependence of this alloy was constructed.

\section{F-8}

\section{TEMPERATURE DEPENDENCE OF THE} STRENGTH, PLASTICITY, AND ELASTIC PROPERTIES OF ALLOYS OF URANIUM WITH ZIRCONIUM, NIOBIUM, AND MOLYBDENUM. V. A. Bugrov, V. K. Grigorovich, and O. S. Ivanov. Fiziko-Khimiya Splavov $i$ Tugoplavkikh Soedinenii s Torirm $i$ Uranon, Izdatel'stvo Nauka 62-69. Moscow, Russia. 1968. 21p. (A translation by A. M. A. Mincer appears as UCRL-tr-10454.)

Investigation of the temperature dependence of the strength of uranium alloys $\mathrm{U}+20$ at $\% \mathrm{Zr}$, $\mathrm{U}+20$ at $\% \mathrm{Nb}, \mathrm{U}+20$ at $\% \mathrm{Mo}, \mathrm{U}+7.5$ at $\%$ $\mathrm{Zr}+15$ at $\% \mathrm{Nb}$, and $\mathrm{U}+10$ at $\% \mathrm{Zr}+20$ at $\%$ $\mathrm{Nb}$ showed that below the transformation temperature (at $500^{\circ} \mathrm{C}$ ) the $\mathrm{U}+20$ at $\% \mathrm{Zr}$ and $\mathrm{U}+70$ at $\% \mathrm{Zr}$ alloys are stronger than the $\mathrm{U}+20$ at $\% \mathrm{Nb}$ (or $\mathrm{U}+20$ at \% Mo) alloys, but not so strong as the compositions $\mathrm{U}+10$ at $\% \mathrm{Zr}$ and $\mathrm{U}+20$ at $\% \mathrm{Nb}$. In the $\gamma$ state (at 700 to $900{ }^{\circ} \mathrm{C}$ ) the $\mathrm{U}+20$ at $\% \mathrm{Zr}$ and $\mathrm{U}+70$ at $\% \mathrm{Zr}$ alloys are far weaker than $\mathrm{U}+20$ at $\% \mathrm{Nb}$ and $\mathrm{U}+20$ at $\%$ Mo. The ternary composition $\mathrm{U}+10$ at $\% \mathrm{Zr}+20$ at $\% \mathrm{Nb}$ is the one most heat resistant in the $\gamma$ range. The Young's modulus of the $\mathrm{U}+70$ at $\% \mathrm{Zr}$, $\mathrm{U}+20$ at $\% \mathrm{Nb}, \mathrm{U}+20$ at $\% \mathrm{Ti}$ and $\mathrm{U}+7.5$ at $\% \mathrm{Zr}+15$ at $\% \mathrm{Nb}$ decreases smoothly to temperatures of phase transformation, then falls sharply within the phase transformation interval, and finally continues to decrease slowly at higher temperatures.
F-9

BROOKHAVEN PULSED FAST RESEARCH

REACTOR. J. M. Hendrie, K. C. Hoffman, H. J. C. Kouts, R. J. Parsick, J. P. Phelps, G. A. Price, M. Reich, H. Takahashi, and H. H. Windsor. Report BNL-13208. Jan 1969. 69p.

The repetitively pulsed fast reactor is of interest as a high intensity source for neutron beam experiments. The design characteristics of a conceptual pulsed reactor operative at an average power of 30 megawatt (MW) are discussed.

The peak power during a pulse is about $4,700 \mathrm{MW}$ and the pulse width at half-maximum power is 90 microseconds. The reactivity is varied by means of reflector sections carried past a bare face of the core on high speed rotors. A tworotor system is preferred in order to provide for variation of the repetition rate between 20 and 60 pulses/second. The performance of the system described is limited by the ability of the fuel to withstand the cyclic thermal and inertial stresses caused by power pulsing. The high cycle fatigue strength of a cermet fuel with a Mo matrix was determined in the unirradiated condition and these data were used as the basis for the core design. Development and test work on this fuel and on other potential pulsed reactor fuels such as $\mathrm{Nb}-\mathrm{U}-\mathrm{Zr}$ ternary alloys and a Th-U dispersion are outlined. A series of critical experiments and beam source optimization studies were performed in support of the design effort and those are described. The tensile properties of $\mathrm{U}-\mathrm{Nb}-\mathrm{Zr}$ alloys and effect of composition thereon are described.

\section{F-10}

SCANNING ELECTRON MICROSCOPE FRACTOGRAPHY OF A URANIUM-7.5 WEIGHT PERCENT NIOBIUM-2.5 WEIGHT PERCENT ZIRCONIUM ALLOY. R. K. Bennett and F. R. Winslow. Report Y-DA-2952. Aug 19, 1969. 18p.

Studies showed that the use of the scanning electron microscope for fractographic study instead of conventional replica techniques in the transmission electron microscope not only shortened the time necessary to obtain the data, 
but also furnished information concerning the deep cracks which might have been difficult to obtain or even lost using the replica technique.

\section{F-11}

\section{METHOD OF STRESS RELAXATION}

TESTING. C. A. Reeves, Jr. Report Y-1726. June 24, 1970. 28p.

Two separate series of tests were performed to determine the stress relaxation properties of a uranium alloy (90 wt \% U, $7.5 \mathrm{wt} \% \mathrm{Nb}$, $2.5 \mathrm{wt} \% \mathrm{Zr}$ ) at both room and elevated temperatures. Only the testing procedure and initial treatment of data are discussed.

\section{F-12}

\section{TRANSFORMATION KINETICS AND} MECHANICAL PROPERTIES OF THE URANIUM-7.5 NIOBIUM-2.5 ZIRCONIUM TERNARY ALLOY. R. J. Jackson and J. F. Boland. Report RFP-1652. Dec 21, 1971. 13p.

Tensile and impact test data are presented for the U-7.5 wt \% Nb-2.5 wt \% Zr ternary alloy in the gamma quenched and aged conditions. The mechanical test data are correlated with metallographic and X-ray studies. These alloys, although transition-phase, supersaturated solid solutions, are weakest in the as-quenched condition. Aging the alloys for up to 80-hour periods at temperatures below $400{ }^{\circ} \mathrm{C}$ results in a noticeable increase in strength with no loss in supersaturation. The data are interpreted in terms of plastic deformation occurring by the motion of twin interfaces and in the pinning of twin interfaces by ordering on aging. A wide variety of mechanical properties are available from this heat treatable and corrosion-resistant alloy, and it shows promise as an economic, high-density, engineering material in both nuclear and non-nuclear applications.

\section{F-13}

EVALUATION OF URANIUM ALLOYS.

W. C. Erickson, G. E. Jaynes, D. J. Sandstrom, R. Seegmiller, and J. M. Taub. Report LA-5002. Sept 1972. 19p.

The oxidation resistance and mechanical properties of 23 uranium alloys have been evaluated. The U-Ti alloys had good mechanical properties, whereas U-Nb alloys had the best oxidation resistance. Mechanical and corrosion properties of $\mathrm{U}-\mathrm{Nb}-\mathrm{Zr}$ alloys are included.

\section{$\underline{\mathbf{G}}$ \\ SHAPE STABILITY}

G-1

DIMENSIONALLY STABLE, CORROSION RESISTANT NUCLEAR FUEL. J. H. Kittel (to U.S. Atomic Energy Commission). U.S. Patent 3,089,768. 1960.

A method of making a uranium alloy of improved corrosion resistance and dimensional stability is described. The alloy contains from 0 to 9 weight percent of an additive of zirconium and niobium in the proportions by weight of 5 to 1.5 . The alloy is cold rolled, heated to two different temperatures, air-cooled, heated to a third temperature, and quenched in water:

\section{G-2}

DIMENSIONALLY STABLE AND CORROSION RESISTANT NUCLEAR FUEL. (to U. S. A tomic Energy Commission.) French Patent 1,314,903. Dec 3, 1962. Priority date Mar 1, 1961, United States.

$\mathrm{U}-\mathrm{Zr}-\mathrm{Nb}$ alloys were prepared with a $\mathrm{Zr}: \mathrm{Nb}$ : weight ratio of $5: 1.5$. The alloys were rendered dimensionally stable and corrosion resistant by the following succession of treatments: cold rolling, short-time heating to effect a rapid transition in the gamma phase, prolonged heating to effect transition in the alpha + beta + gamma phase, cooling, short-time heating to effect a rapid transition in the gamma phase, and quenching. As an example, an alloy with 6.5 wt $\% \mathrm{Nb}+\mathrm{Zr}$ was treated as follows: rolled at $25^{\circ} \mathrm{C}$ to give a decrease in thickness of $12 \%$, heated at $800^{\circ} \mathrm{C}$ for 15 minutes, heated at $650^{\circ} \mathrm{C}$ for 24 hours, cooled at $25^{\circ} \mathrm{C}$, heated at $800^{\circ} \mathrm{C}$ for 15 minutes, and quenched.

\section{G-3}

EFFECTS OF THERMAL CYCLING ON THE BEHAVIOR OF URANIUM-ZIRCONIUMNIOBIUM ALLOYS. L. A. Gomozov and 
O. S. Ivanov. Stroenie i Svoistva Splavov Urana, Toriya i Tsirkoniya 169-174. Moscow,

Gostomizdat, Russia. 1963.

Studies of $\gamma$ phase U-Zr-Nb stability to thermal cycling between $35 \rightleftharpoons 800^{\circ} \mathrm{C}$ (500 cycles) indicated that $a \rightleftharpoons \beta \rightleftharpoons \gamma$ transitions were achieved for low-alloyed and $a \rightleftharpoons \gamma$ transitions for high-alloyed systems. Specimens with 15 at $\% \mathrm{Nb}$ and 55 to 57 at $\% \mathrm{Zr}$ exhibited a rough surface that was smoothed out by increasing the amount of $\mathrm{Nb}$. Cyclic treatment did not alter the surface or dimensions of binary alloys containing more than 20 at \% Nb or 97 at $\% \mathrm{Zr}$. Introduction of $\mathrm{Zr}$ into binary $\mathrm{U}-\mathrm{Nb}$ alloys with $\mathrm{Zr}$ at \%:Nb at \% ratios of $2: 3$ to $1: 1$ did not reduce the alloy stability to thermal cycling. However the effective thermal neutron capture cross section is reduced.

$\underline{\mathbf{H}}$

\section{CHEMICAL DISSOLUTION, SEPARATION, AND REPROCESSING}

\section{H-1}

\section{PROCESSING OF REACTOR FUELS IN} MOLTEN 3 ZIRCONIUM TETRACHLORIDE2 PHOSPHORUS OXYTRICHLORIDE. T. A.

Gens. Report CF-58-1-49. Jan 6, 1958.

Declassified Dec 10, 1958. 7p.

Dissolution rates of approximately $10 \mathrm{mg} / \mathrm{min}-\mathrm{cm}^{2}$ have been obtained with all fuel alloys (including $\mathrm{U}-\mathrm{Nb}-\mathrm{Zr}$ alloys) that have been tried. Uranium recovery of about $97 \%$ was achieved in the only run in which a material balance was obtained. A residue, insoluble in nitric acid, was found to contain up to $2.5 \%$ of the uranium that had dissolved in the melt. This quantity of uranium cannot be considered a loss unless further studies show that it cannot be dissolved by simple variation in technique. In the first experiment, the nitric acid contained half as much phosphate as uranium by weight. A simple variation in procedure in the next experiment reduced the phosphate-uranium weight ratio to $1: 50$. Nichrome $V$ seems to be a suitable and practical material of construction.

\section{H-2}

NEW DEVELOPMENTS IN URANIUMZIRCONIUM ALLOY FUEL REPROCESSING.

T. A. Gens (ORNL). Nuclear Sci. and Eng. 9:488-494. Apr 1961.

Processes for dissolving $\mathrm{U}-\mathrm{Zr}$ and $\mathrm{Nb}-\mathrm{U}-\mathrm{Zr}$ alloy fuels in ammonium fluoride solutions (Modified Zirflex processes) are developed. A nonaqueous process (Zircex process), in which high-zirconium alloys are hydro-chlorinated at about $600{ }^{\circ} \mathrm{C}$, offers the possibility of zirconium separation prior to solvent extraction. Dissolvents consisting of hydrofluoric acid-hydrogen peroxide or hydrofluoric acid-nitric acid-aluminum nitrate mixtures are also attractive, but corrosion rates with common construction materials prove excessively high.

\section{$\underline{I}$}

\section{CHEMICAL ANALYSIS}

I-1

COMPLETE ANALYSIS OF URANIUMNIOBIUM-ZIRCONIUM ALLOY BY X-RAY ABSORPTION EDGE TECHNIQUE. J. H. Stewart Jr., T. H. Barton Jr., and M. R. Ferguson (ORNL). Anal. Chem. 40:27-29. Jan 1968.

The X-ray absorption edge technique was extended to include the complete analysis of a $\mathrm{U}-\mathrm{Nb}-\mathrm{Zr}$ alloy. The alloy was dissolved in $6 \mathrm{~N} \mathrm{HCl}, \mathrm{HNO}_{3}$ and $\mathrm{HF}$ were added, and the $\mathrm{U}$ determined: A rapid tri-n-butyl phosphate (TBP) extraction removed the bulk uranium. $\mathrm{Nb}$ and $\mathrm{Zr}$ were then both determined in the aqueous phase. The intensity of the transmitted primary X-ray beam taken at wavelengths on each side of the three absorption edges was used to determine the concentrations of the three components. Twelve samples may be analyzed for the three components in an 8-hr period. The relative standard deviation of this method for the analysis of metal chips is $0.34 \%$ for $U$, $0.90 \%$ for $\mathrm{Nb}$, and $2.2 \%$ for $\mathrm{Zr}$.

\section{I-2 \\ QUANTITATIVE ANALYSIS OF MICROMETRE-SIZE URANIUM ALLOY}


POWDERS USING THE ELECTRON MICROPROBE X-RAY ANALYZER. J. H. Stewart Jr. Report Y-1745. Sep 22, 1970. 77p.

The electron probe was used in the quantitative analysis of individual microparticles of uraniummolybdenum and uranium-niobium-zirconium alloys. A computer program was applied to correct the characteristic X-ray intensities of the alloyed metals excited by the electron beam for absorption, fluorescence, and atomic number effects. The accuracy of the method is comparable to that of the conventional chemical analysis of homogeneous bulk samples. A simplified specimen preparation and handling procedure were devised to prevent the usual rapid oxidation of the polished specimen surface, which would introduce a significant nonreproducible bias into the analysis.

\section{$\underline{\mathbf{J}}$}

\section{CORROSION AND OXIDATION}

\section{J-1}

\section{PRELIMINARY REPORT ON CORROSION OF URANIUM-BASE ALLOYS CONTAINING NIOBIUM AND ZIRCONIUM. A. E. Dwight} and A. H. Roebuck. Report ANL-5376. Dec 19, 1954. Declassified Apr 4, 1957. 21p.

Tests were made to determine the cffects of composition and heat treatment on the corrosion resistance and hardness of samples of arc-melted, unclad U-Nh- $\mathrm{Zr}$ alloys exposed to static, degassed water at $400^{\circ} \mathrm{F}$. Samples of eleven compositions were tested; eight different heat treatments were utilized. Specimens quenched from the gamma and beta ranges exhibited varying degrecs of corrosion resistance, while alpha-annealed or furnace-cooled specimens disintegrated after testing for 168 hours. In general, the specimens having a Rockwell $\mathrm{C}$ hardness of $<20$ exhibited the best corrosion resistance. For alloys comparable to these used in this investigation ( 640 to $785 \mathrm{ppm} \mathrm{C} ; 38$ to $14 \mathrm{ppm} \mathrm{N}$ ), the ternary compositions ranging from approximately 2 to $4 \mathrm{wt} \% \mathrm{Zr}$, and from 3 to $5 \% \mathrm{Nb}$, balance $\mathrm{U}$, are the most promising for further investigation.
J-2

THE CORROSION PROPERTIES OF ZIRCONIUM-BASE FUEL ALLOYS. S. Kass. Report WAPD-136. Nov 2, 1955. Declassified Aug 17, 1956. 41p.

The $\mathrm{Zr}-4$ wt \% U-8 wt \% Nb alloy shows excellent promise as a corrosion-resistant fuel alloy. The oxide films form very slowly and are adherent at least for 84 days in $680^{\circ} \mathrm{F}$ water.

\section{J-3}

THE HIGH TEMPERATURE AQUEOUS CORROSION OF URANIUM ALLOYS CONTAINING MINOR AMOUNTS OF NIOBIUM AND ZIRCONIUM. J. E. Draley, S. Greenberg, and W. E. Ruther. Report ANL-5530. Apr 1957. 45p.

Of those alloys tried, the alloy with best resistance to thermal aging is the $\mathrm{U}-5 \% \mathrm{Zr}-1.5 \%$ $\mathrm{Nb}$ alloy. At $290^{\circ} \mathrm{C}$, optimum heat treatment can result in a rate of corrosion of about $6 \mathrm{mg} / \mathrm{cm}^{2} /$ day. Certain moderate aging treat:ments, e.g., $400{ }^{\circ} \mathrm{C}$ for two hours, result in improved corrosion resistance in the initial stages of corrosion.

\section{J-4}

INFLUENCE OF RADIATION UPON CORROSION AND SURFACE REACTIONS: OF METALS AND ALLOYS. M. T. Simnad. Report GA-130. 1957. 28p.

A discussion of various factors in corrosion of irradiated metallic surfaces is presented. The usual mechanisms of metallic corrosion, such as direct chemical reactions, direct solution (mass transfer), and electrochemical mechanisms, are considered in relation to the effects of light and $X$ rays. In addition, corrosion of reactor materials (including U-Nb-Zr alloys) in aqueous materials is considered. The effect of irradiation on gas-solid reactions is discussed as well as proton irradiation effects on surface reactions. Several tables and graphs are included.

\section{J-5}

CORROSION OF IRRADIATED URANIUM ALLOYS. S. Greenberg (ANL). Nuclear Sci. and Eng. 6:159. Aug 1959. 
As a result of heat treatment under irradiation, $\mathrm{U}-\mathrm{Nb}-\mathrm{Zr}$ alloys exhibited corrosion rates at $260^{\circ} \mathrm{C}$ in initially pure water as low as $1880 \mathrm{mg} / \mathrm{cm}^{2} /$ day. Rates are based on original exposed area.

\section{J-6}

HIGH TEMPERATURE AQUEOUS CORROSION OF URANIUM ALLOY்S CONTAINING MINOR AMOUNTS OF ALLOYING ELEMENTS. J. E. Draley (ANL). Report TID-7587. p.390-404.

The corrosion resistance of $\mathrm{U}-\mathrm{Zr}, \mathrm{Nb}-\mathrm{U}-\mathrm{Zr}$, $\mathrm{Nb}-\mathrm{U}, \mathrm{Nb}-\mathrm{Sn}-\mathrm{U}, \mathrm{Si}-\mathrm{U}$, and Al-Ni-U alloys in high-temperature water was investigated.

\section{J-7}

CORROSION RESISTANCE OF SOME URANIUM ALLOYS. L. I. Gomozov and O. S. Ivanov. Stroenie i Svoistva Splavov Urana, Toriya i Tsirkoniya 175-184. Moscow, Gosatomizdat, Russia. 1963.

Tests were made with homogenized, welded, cylindrical, $5 \times 22-\mathrm{mm}$ alloy bars prepared from 99.84\% pure $U, 99.8 \%$ pure iodide zirconium, and $99.2 \%$ sintered $\mathrm{Nb}$ with $0.3 \% \mathrm{Ta}$ and $0.25 \% \mathrm{Ti}$. Corrosion stability of alloys annealed from the $\gamma$ phase in 300 to $400{ }^{\circ} \mathrm{C}$ water is enhanced with increased $\gamma$-phase stability. The highest corrosion resistance was found with a $\mathrm{Zr}$ at \%:Nb at \% ratio of $2: 3$. High-alloyed uranium with niobium or molybdenum is easily inhibited in 250 to $300{ }^{\circ} \mathrm{C}$ water. An optimum content of 20 to 27 at \% of Nb or Mo is suggested.

A group of corrosion resistant low uranium alloys is given in increasing order of resistance: 5 at \% U-95 at $\% \mathrm{Zr}, 2$ at \% U-0.5 at \% Nb-97.5 at $\% \mathrm{Zr}, 2$ at $\% \mathrm{U}-0.5$ at $\% \mathrm{Nb}-0.5$ at $\% \mathrm{Sn}-97$ at $\% \mathrm{Zr}, 8$ at $\% \mathrm{U}-46$ at $\% \mathrm{Nb}-46$ at $\% \mathrm{Zr}$, 5 at \% U-1 5 at $\%$ Nb-2 at \% Sn-2 at \% Cs-76 at $\% \mathrm{Zr}$. Alloys with a high scale resistance at 650 to $750{ }^{\circ} \mathrm{C}$ tend toward a binary composition of 25 at $\% \mathrm{Nb}-75$ at $\% \mathrm{Zr}$, forming a solid solution base. Scale resistance of U-Mo alloys is higher with 17 at \% Mo and in ternary alloys with 17 to 23 at $\%$ Mo and 2 to 3 at $\% \mathrm{Zr}$.
J-8

CORROSION RESISTANCE IN WATER OF SOME ALLOYS OF URANIUM WITH ZIRCONIUM, NIOBIUM, AND MOLYBDENUM. V. B. Kishinevskii, L. I. Gomozov, and O. S. Ivanov. Fiziko-Khiniya Splavov i Tugoplavkikh Soedinenii s Toriem i Uranom, Izdatel'stvo Nauka 81-86: Moscow, Russia. 1968. 11p. (A translation by A. M. A. Mincer appears as UCRL-Trans-10455).

Results of investigations showed that in the $\mathrm{U}-\mathrm{Zr}-\mathrm{Nb}$ system, the alloys $\mathrm{U}+(20-30)$ at $\% \mathrm{Nb}$ and $\mathrm{U}+20$ at $\% \mathrm{Zr}$ proved to be the most resistant to corrosion after quenching in water at $100{ }^{\circ} \mathrm{C}$. After tempering the corrusion stability is sharply decreased. The alloys most resistant under the testing conditions were $\mathrm{U}+10$ at $\% \mathrm{Zr}+10$ at $\% \mathrm{Nb}, \mathrm{U}+30$ at $\% \mathrm{Nb}$, and $\mathrm{U}+15$ at $\% \mathrm{Zr}+15$ at $\% \mathrm{Nb}$. The corrosion resistance of quenched U-Zr-Mo alloys in water at $100^{\circ} \mathrm{C}$ is lower than that of the corresponding binary alloys. After tempering, the lowest resistance was found for the alloys in which the $\mathrm{Zr}$ : Mo ratio was $1: 3$. The alloy having the composition $\mathrm{U}+30$ at \% Mo proved to be the most stable in this system. A broad range of alloys resistant to corrosion in water at $100^{\circ} \mathrm{C}$. in the quenched state has been found in the U-Nb-Mo system. After tempering the alloys $\mathrm{U}+15$ at $\% \mathrm{Nb}+5$ at $\%$ Mo and $\mathrm{U}+22.5$ at $\% \mathrm{Mo}+7.5$ at $\% \mathrm{Nb}$ had the highest resistance. Alloys of the 80 at $\% \mathrm{U}$ section in the U-Nb-Mo system and of the 70 at \% U section in the U-Zr-Nb system had the highest corrosion resistance in water at $250^{\circ} \mathrm{C}$.

\section{J-9}

GALVANIC CORROSION BEHAVIOR OF URANIUM ALLOYS IN HYDROCHLORIC ACID AND OCEAN WATER. J. M. Macki and R. L. Kochen. Report RFP-1592. Feb 24, 1971. 9p.

The galvanic corrosion behaviors of a selected group of alloys in ocean water and hydrochloric acid $(\mathrm{HCl})$ were determined by measuring the gravimetric corrosion rates of galvanically coupled specimens and by constructing a galvanic series for each environment from electrode potential measurements. Based on the 
gravimetric-galvanic corrosion tests, the galvanic series of the alloys tested, in the order of increasing nobility in $0.1 \mathrm{~N} \mathrm{HCl}$ at $70^{\circ} \mathrm{C}$ is: $7178 \mathrm{Al}$, Tuballoy (depleted uranium), U-4.5 Nb, Type 4340 steel, U-6 Nb, U-8 Nb, U-7.5 Nb-2.5 Zr (Mulberry), U-10 Mo, Ti-6 $\mathrm{Al}-4 \mathrm{~V}$, and Type 304 steel (passive). The galvanic series, based on electrode potentials, in $0.1 \mathrm{~N} \mathrm{HCl}$ at 25 and $70^{\circ} \mathrm{C}$ and in ocean water at $25^{\circ} \mathrm{C}$, were the same as the series based on the gravimetric-galvanic corrosion tests except for Ti-6 Al-4 V, which occupied a more active position according to the potential measurements. Although they were adjacent to each other in the galvanic series, the Type 4340 steel caused the U-4.5 Nb alloy to corrode an order of magnitude faster than the other more noble metals in the series in $0.1 \mathrm{~N} \mathrm{HCl}$ at $70^{\circ} \mathrm{C}$.

\section{J-10}

\section{REACTION OF MULBERRY WITH VARIOUS}

GASES. R. A. Sallach. Report SC-DR-710124. Feb 1971. 20p.

The reaction of Mulberry (U-7.5 wt \% $\mathrm{Nb}-2.5 \mathrm{wt} \% \mathrm{Zr}$ ) with the gases $\mathrm{CO}_{2}, \mathrm{H}_{2} \mathrm{O}, \mathrm{N}_{2}$, and $\mathrm{O}_{2}$ was surveyed. With $\mathrm{CO}_{2}$ a linear reaction was found at $600{ }^{\circ} \mathrm{C}$. With the other gases, parabolic reactions were generally found; deviations were attributed to spalling of reaction product. Catastrophic reactions with $\mathrm{H}_{2} \mathrm{O}$ and $\mathrm{O}_{2}$ were observed at $600{ }^{\circ} \mathrm{C}$. The reactivity of the gases can be ordered as $\mathrm{O}_{2} \sim \mathrm{H}_{2} \mathrm{O}>\mathrm{N}_{2} \geqslant \mathrm{CO}_{2}$.

\section{J-11}

LOW-TEMPERATURE OXIDATION OF URANIUM-NIOBIUM AND URANIUMNIOBIUM-ZIRCONIUM ALLOYS. J. V. Cathcart and G. F. Petersen (ORNL). J. Nucl. Mater. 43:86-92. May 1972. (See also report ORNL-TM-3587 dated Dec 1971.)

The rates of oxidation of U-9.4 wt \% Nb and U-7.5 wt $\% \mathrm{Nb}-2.5 \mathrm{wt} \% \mathrm{Zr}$ were measured between 100 and $300^{\circ} \mathrm{C}$ in purified oxygen. Arl activation energy of approximately $13 \mathrm{kcal} / \mathrm{mol}$ was obtained for both alloys. The effects of $\mathrm{H}_{2} \mathrm{O}, \mathrm{SO}_{2}$, and $\mathrm{CCl}_{4}$ on the oxidation rate of the ternary alloy were small. Metallographic studies revealed the oxide films to be compact and uniform, although significant oxidation rate anisotropy was observed during the early stages of oxidation.

$\mathrm{J}-12$

HIGH-TEMPERATURE OXIDATION OF URANIUM ALLOYS. J. V. Cathcart, R. E. Pawel, and G. F. Petersen (ORNL). Report CONF-720523-1. 1972. 19p. Fifth International Congress. on Metallic Corrosion, Tokyo, Japan. May 21, 1972.

The oxidation characteristics of U-16.6 at \% $\mathrm{Nb}-5.6$ at $\% \mathrm{Zr}, \mathrm{U}-21$ at $\% \mathrm{Nb}, \mathrm{U}-15$ at $\% \mathrm{Zr}$, and $\mathrm{U}-18$ at $\% \mathrm{Mo}$ in the temperature range 700 to $1100^{\circ} \mathrm{C}$ are discussed. Stresses as large as $10^{6}$ psi develop in the oxide scales on these alloys as oxidation proceeds, and these stresses led to large increases in the lateral dimensions of the specimens. The morphology of the oxide scales is described, and a mechanism of stress generation is suggested. Several stress relief processes, including the plastic deformation of both oxide and metal are discussed.

\section{$\underline{\mathbf{K}}$}

\section{IGNITION AND EXPLOSIVE PROPERTIES}

\section{K-1}

EXPLOSIONS INVOLVING PICKLING OF ZIRCONIUM AND URANIUM ALLOYS.

W. J. Hurford. Report WAPD-84. May 28, 1953. Declassified Jan 6, 1956. 18p.

Reports are submitted in a consolidated form by individual laboratories on explosion hazards involved in etching and pickling $\mathrm{Zr}$ and $\mathrm{U}$ and their alloys (including $\mathrm{U}-\mathrm{Nb}-\mathrm{Zr}$ ).

\section{K-2}

EXPLOSION OF EBWR ALLOY IN BOILING CONCENTRATED NITRIC ACID. F. G. Baird, T. A. Gens, and L. M. Ferris. Report CF-58-10-43. Oct 9, 1958. 3p.

An explosion which occurred while dissolving EBWR core alloy (93.5\% U-5.07\% $\mathrm{Zr}-1.5 \% \mathrm{Nb}$ ) in boiling concentrated nitric acid is described. 
K-3

EXPLOSIVE REACTIONS DURING

REPROCESSING OF REACTOR FUELS CONTAINING URANIUM AND ZIRCONIUM OR NIOBIUM. T. A. Gens. Report CF-58-11-31. Nov 13, 1958. 11p.

Small particles of metallic phases rich in zirconium or niobium, produced by selective leaching of a more reactive uranium-rich phase, can enter into violently explosive reactions. The conditions under which explosions with zirconium-bearing alloys may be expected during chemical reprocessing have been defined in the literature. The uranium-zirconium alloys containing less than $30 \mathrm{wt} \%$ zirconium are hazardous when they contact nitric acid. Laboratory work has shown that potentially explosive zirconium alloys may be safely dissolved in nitric acid if enough fluoride ion is added to maintain a mole ratio of fluoride to dissolved zirconium of four. Niobium-bearing fuel alloys can also explode after contacting nitric acid, but the conditions which produce explosions have not yet been studied thoroughly.

Dissolution studies.with the EBWR alloy $(93.5 \% \mathrm{U}, 5 \% \mathrm{Zr}, 1.5 \% \mathrm{Nb})$ indicate that hazardous niobium alloys can also be processed safely in nitric acid by addition of enough fluoride to prevent formation of surface deposits. The ternary phase diagram for zirconiumuranium-oxygen shows that the epsilon phase is unstable at the interface between a zirconium or a Zircaloy- 2 cladding and a uranium oxide core. These fuels can be processed by techniques which require contact with nitric acid without fear of epsilon-phase explosions.

$\underline{\mathbf{L}}$

\section{SURFACE STUDIES AND COATINGS}

\section{L-1}

THE ROLE OF LATTICE MISMATCH BETWEEN OXIDE AND METAL IN THE CORROSION BEHAVIOR OF GAMMA URANIUM ALLOYS. J. N. Chirigos (WAPD).
"Physical Metallurgy of Stress Corrosion Fracture," Pages 70-78. A Symposium [held at] Pittsburgh, Pennsylvania, Apr 2-3, 1959. Thor N. Rhodin, Editor. Interscience Publishers, New York. 1959. 405p.

Experiments were carried out on gamma U alloys in order to study the reasons for their discontinuous corrosion failure after a period of steady corrosion in hot water. Alloys of $\mathrm{U}+10 \mathrm{wt} \% \mathrm{Nb}$ with 0 to $10 \mathrm{wt} \% \mathrm{Zr}$ were found to give the same corrosion behavior and life (to discontinuous failure) when tested in $\mathrm{O}_{2}$ at $680^{\circ} \mathrm{F}$ and $12 \mathrm{~cm} \mathrm{Hg}$ as in water at $680^{\circ} \mathrm{F}$ and 2650 psi. Use of the Frank-Van der Merwe (F-M) theory of oriented overgrowths in calculations gave the result of 1 -micrometre $(\mu \mathrm{m})$ thick $\mathrm{UO}_{2}$ films as being sufficient to strain the alloy metal to its breaking point through its coherency to the metal. This agrees well with experiment, which shows that a corrosion product film forms up to about $1-\mu \mathrm{m}$ thickness, after which the thickness remains constant, followed by a weight loss due to flaking and failure by cracking or splitting. Moreover, experiments with exposure of $\mathrm{U}+10 \mathrm{wt} \% \mathrm{Nb}$ alloys to sulfur and iodine vapors gave discontinuous failure, indicating that the chemical composition of the film or corrosion medium is not important, as suggested by the F-M theory.

Further support for the F-M theory is given by plots of corrosion life versus $\% \mathrm{Zr}$ and of lattice nonregistry versus $\% \mathrm{Zr}$ for corrosion of $\mathrm{U}+10 \mathrm{wt} \% \mathrm{Nb}$ with varying $\mathrm{Zr}$ contents; maxima in the former correspond to minima in the latter and vice versa. A plot of corrosion life versus $1 / r^{4}$, where $r$ is the grain radius, is approximately linear and supports the assumption that the mismatch stress between oxide and metal acts only across the oxide-metal interface over one grain. The activation energy is given by a plot of $-1 \mathrm{~nL}_{\mathrm{O}}\left(\mathrm{L}_{\mathrm{o}}=\right.$ corrosion life at $r=\infty$ ) versus $1 / T, 26.6 \mathrm{kcal}$, in agreement with that found by Antill for diffusion of $\mathrm{O}_{2}$ in $\mathrm{UO}_{2}$. Tracer studies confirmed the hypothesis that $U$ alloys corrode by anion diffusion through the oxide in both $\mathrm{O}_{2}$ and water. It is concluded that there is good evidence for the role of lattice mismatch between metal and corrosion product in governing the corrosion life of gamma $\mathrm{U}$ alloys. 


\section{L-2}

X-RAY STUDY OF OXIDATION OF A TERNARY ALLOY OF URANIUM-7.5 PERCENT NIOBIUM-2.5 PERCENT ZIRCONIUM (MULBERRY ALLOY). K. Terada and H. A. Goad. Report RFP-1485. June 23, 1970. 11 p.

The X-ray diffraction study of the oxidation of Mulberry alloy is described. Experiments were performed at $150,250,400,500$, and $600^{\circ} \mathrm{C}$ in both dry and wet air, and with different surface preparation of the samples. Only $\mathrm{UO}_{2}$ was formed at 150 and $250{ }^{\circ} \mathrm{C}$. At $400^{\circ} \mathrm{C}$, $\mathrm{U}_{3} \mathrm{O}_{8}$ was also formed after induction periods ranging from one-quarter to 10 hours. $\mathrm{U}_{3} \mathrm{O}_{8}$ was formed almost immediately at 500 and $600^{\circ} \mathrm{C}$. The moisturc content of the oxidizing atmosphere and the surface sample pretreatment did not appear to have any cffect on the results.

L-3

OXIDATION OF A TERNARY URANIUM

ALLOY. D. T. Larson (RFP). J. Vac. Sci. Technol. 8:80-83 Jan-Feb 1971.

The effect of alloying uranium. with $7.5 \mathrm{wt} \% \mathrm{Nb}$ and $2.5 \mathrm{wt} \% \mathrm{Zr}$ (Mulberry alloy) on the initial oxidation kinetics (surface oxide thicknesses up to $2000 \AA$ ) in air containing water vapor was investigated using an ellipsometer high vacuum system. The uranium alloy samples were oxidized in dry air $\left(<5 \mathrm{ppm} \mathrm{H}_{2} \mathrm{O}\right)$ and air containing water vapor $\left(15,000 \mathrm{ppm} \mathrm{H}_{2} \mathrm{O}\right)$ at a pressure of 650 torr in a temperature range of 22 to $200^{\circ} \mathrm{C}$. The results differed from the oxidation of uranium in that the oxidation of this uranium alloy was not enhanced by water vapor under the conditions studied. The oxidation followed a parabolic-rate, indicating a diffusion-controlled mechanism. An Arrhenius plot of the parabolic reaction rates as a function of the reciprocal temperature revealed a difference in the activation energy of the low-temperature $\left(22\right.$ to $100^{\circ} \mathrm{C}$ ) and high-temperature $\left(100\right.$ to $200^{\circ} \mathrm{C}$ ) oxidation.

\section{L-4}

OXIDATION PROPERTIES OF URANIUM-16.6 ATOMIC PERCENT NIOBIUM-5.6 ATOMIC PERCENT ZIRCONIUM AND URANIUM-21 ATOMIC PERCENT NIOBIUM. J. V. Cathcart, R. E. Pawel, and G. F. Petersen (ORNL).

Oxidation Metals 3:497-521. Nov 1971. [This study also appears as Report Y-1800 dated Oct 26, 1971.]

The fundamental oxidation characteristics of two U-base alloys U-16.6 at \% Nb-5.6 at \% $\mathrm{Zr}$ and $\mathrm{U}-21$ at $\% \mathrm{Nb}$, in the temperature range 500 to $1000{ }^{\circ} \mathrm{C}$ in oxygen at 0.05 torr are described. Both alloys undergo large dimensional changes during oxidation at temperatures above $650^{\circ} \mathrm{C}$ due to stresses generated in the oxide during oxidation. Oxidation rate curves for both alloys were determined at $100{ }^{\circ} \mathrm{C}$ intervals between 500 and $1000^{\circ} \mathrm{C}$; the activation energy for the process was found to be small. The morphology of the oxide scale formed on the two alloys was complex and is described in detail. Stresses estimated at $10^{6}$ psi were found to develop in oxidizing specimens, and a mechanism for the generation of these stresses is proposed.

\section{L-5}

MECHANICAL PROPERTIES OF SCALES AND THEIR INFLUENCE ON HIGH- : TEMPERATURE GAS-METAL REACTIONS.

J. V. Cathcart (ORNL). Report CONF-720515-1. 1972. 22p. Fourth Annual Spring Meeting of the Metallurgical Society of AIME, Boston, Massachusetts. May 8, 1972.

It is shown that surface stresses between $10^{5}$ and $10^{6}$ psi are frequently generated during oxidation of metals, and several stress generating mechanisms are discussed. The influence of such stresses on scale rupture, structure, and morphology, on diffusion rates within the scales, and on the shape change experienced by oxidation specimens is pointed out. Evidence for extensive hightemperature plasticity in oxides is cited, and the oxidation behavior of two U-base alloys is described by way of emphasizing the importance of the mechanical properties of scales in gasmetal reactions.

\section{M \\ STRESS CORROSION}

M-1
FACTORS INFLUENCING STRESS CORROSION OF REACTOR MATERIALS. 
W. E. Tragert (GEPM). Corrosion et anti-corrosion 8:196-201. May 1960. (In French)

An explanation is sought for the formation of fissures in metals and alloys by stress corrosion, in the light of a number of hypotheses. These hypotheses are classed into electrochemical mechanisms, electrochemical-mechanical mechanisms, and mechanisms involving fissuring by absorption of constraints. In the case of stress corrosion of $\mathrm{U}$ alloys (including $\mathrm{U}-\mathrm{Nb}-\mathrm{Zr}$ ); the extents to which the various hypotheses are able to explain the observed phenomena are discussed.

\section{M-2}

FACTORS INVOLVED IN THE CORROSION UNDER STRAIN OF MATERIALS USED IN REACTORS. W. E. Tragert. Corros. Anti-Corros. 8:196-201. 1960. 19p. [A translation of this article by R. Gregg Mansfield appears as ORNL-tr-2154.]

An attempt has been made to explain the formation of fissures by corrosion under strain in metals and alloys in the light of certain hypotheses which have been proposed and which are classified into various concepts: electrochemical-mechanisms, electrochemicalmechanical concepts, fissuring by absorption of stresses. In the case of corrosion of uranium alloys, the contribution that these theories can make to the explanation of observed phenomena is discussed.

\section{M-3}

\section{STRESS CORROSION OF URANIUM}

ALLOYS. G. A. Whitlow. Report AWRE-0-49/66. 1966. 18p.

The phenomenon of stress corrosion in binary uranium-molybdenum alloys was examined, revealing acicular precipitation associated with fracture. This may be due to reaction between uranium and moisture, not oxygen, producing atomic hydrogen. A uranium-7.5 wt \% niobium-2.5 wt \% zirconium alloy is also shown to be susceptible to stress corrosion in high humidity environments.

\section{M-4}

DELAYED CRACKING STUDY IN URANIUM7.5 PERCENT NIOBIUM-2.5 PERCENT
ZIRCONIUM. C. A. W. Peterson and W. J. Steele. Report UCID-15256. Dec 19, 1967. 37p.

Two types of tests were used to evaluate the delayed cracking propensity in $\mathrm{U}-7.5 \% \mathrm{Nb}-2.5 \%$ $\mathrm{Zr}$ (Mulberry): sustained loading near the yield strength in dry and wet air; and dynamic testing to failure over a range of strain rates ( 0.05 to $0.005 \mathrm{in} / \mathrm{in} / \mathrm{min})$ in dry air, wet air, and vacuum. Two conditions of constitution were examined: solution treated by quenching from. the gamma field, and solution treated plus aging at $150{ }^{\circ} \mathrm{C}$ for 1 hour. The effects of mechanical notches and pre-existing intergranular penetrations were also observed. Specimens which had been machined after heat treatment and thus presented a clean, machined surface to the atmosphere while under stress did not fail in creep or show low elongation at low strain rates. Tests to failure produced ductile fracture surfaces. Indications of surface damage by oxidation, gouging or scoring to form minute notches, and inclusions, as well as intergranular penetration and substructural contamination, are seen in the many optical and electron microstructures of brittle fractures. The gamma-quenched specimens so contaminated appeared to be more susceptible to failure in the humid environment than samples heat-treated at $150^{\circ} \mathrm{C}$ or machined after all heat treatments.

Resistivity measurements and X-ray data show that gamma-quenched Mulberry specimens are highly stressed, particularly on the surface, from the quenching. The $150^{\circ} \mathrm{C}$ aging treatment relieves this condition, as evidenced by the sharpening of the $\gamma-U(110)$ line and by a pronounced drop in electrical resistance. Of course, machining the surface would also relieve stresses on the surface. Apparently, failure occurs on $\mathrm{U}-7.5 \% \mathrm{Nb}-2.5 \% \mathrm{Zr}$ when the surface is both in a state of high residual tensile stress and is impaired by localized stress-raisers, such as oxide inclusions (particularly intergranular penetrations) and mechanical notches. When these same surfaces are relieved of stress by fine machining or etching and freed from oxide layers, delayed cracking does not occur, even near the nominal yield strength of the alloy. 
M-5

RAPID TEST FOR STRESS-CORROSION CRACKING. S. Orman (AWRE). Corros. Sci. 9:849-851. Nov 1969.

A simple rapid test was used to examine the susceptibility to stress-corrosion cracking of a variety of alloys. The results are in agreement with those from longer term tests. The advantages claimed for this test are speed of assessment and the use of standard laboratory apparatus. Alloys examined included U-10 wt \% Mo, U-7.5 wt \% Mo, U-7 wt \% Nb-2.5 wt \% Zr, U-6 wt \% Nb, mild steel and stainless steel, $a$-recrystallized $U$ was also tested.

\section{M-6}

A STUDY OF THE STRESS CORROSION CRACKING BEHAVIOR OF MULBERRY (URANIUM-7.5 WEIGHT PERCENT NIOBIUM-2.5 WEIGHT PERCENT ZIRCONIUM). N. J. Magnani, H. Romero, and C. J. Miglionico. Report SC-RR-70-371. May 1970. 35p.

An investigation of the uranium base alloy, Mulberry (nominal composition of $90 \mathrm{wt} \% \mathrm{U}$, $7.5 \mathrm{wt} \% \mathrm{Nb}$, and $2.5 \mathrm{wt} \% \mathrm{Zr}$ ) was conducted to characterize the stress corrosion cracking behavior of the alloy. Two stress corrosion cracking modes were observed: quasi-cleavage (transgranular) and intergranular. The transgranular mode required $\mathrm{O}_{2}$ for propagation and had a critical stress intensity for crack propagation of approximately $20 \mathrm{ksi} / \mathrm{inch}$. The intergranular mode occurred both in high relative humidity air and in an aqueous environment. The critical stress intensity for crack propagation of the intergranular mode is below $10 \mathrm{ksi} / \mathrm{inch}$.

\section{M-7}

\section{SURVEY OF FACTORS WHICH INFLUENCE} STRESS CORROSION CRACK INITIATION IN SEVERAL URANIUM BASE ALLOYS. $L$. $L$. Stephenson. Report SC-DR-70-718. Oct 1970. 25p.

The effect of a number of metallurgical and electrochemical variables on the initiation phase of stress corrosion cracking in Mulberry (U-7.5\% Nb-2.5\% Zr), U-4.5\% Nb, U-6.5\% Nb, and $\mathrm{U}-8.5 \% \mathrm{Nb}$ alloys was determined. $\mathrm{A}$ potentiostat was used to establish the passivation behavior of Mulberry in several different solutions. Bend specimens, immersed in aqueous solutions and held at constant potentials, were used to investigate the stress corrosion crack initiation characteristics of the various alloys. The effect of potential on the mode of crack growth in Mulberry in dilute $\mathrm{KCl}$ solutions was determined.

M-8

EFFECT OF CHLORIDE IONS ON THE SUSCEPTIBILITY TO STRESS CORROSION CRACKING OF URANIUM-7.5 WEIGHT PERCENT NIOBIUM-2.5 WEIGHT PERCENT ZIRCONIUM AND URANIUM-4.5 WEIGHT PERCENT NIOBIUM ALLOYS. N. J. Magnani, H. Romero, and C. J. Miglionico. Report SC-RR-70-860. Dec 1970. 23p.

The effect of chloride ions on the stress corrosion cracking behavior of U-7.5 wt \% Nb-2.5 wt $\% \mathrm{Zr}$ (Mulberry) and U-4.5 wt \% Nb was studied in this investigation. The fracture mode and critical stress intensity for stress corrosion cracking ( $\mathrm{K}_{\text {ISCC }}$ ) of Mulberry were strongly dependent on chloride concentration. A mixed transgranular (quasi-cleavage) and intergranular mode was observed in Mulberry tested in solutions of $<2 \mathrm{ppm} \mathrm{Cl}$; this type of cracking had a $\mathrm{K}_{\mathrm{ISCC}}$ value of $15 \mathrm{ksi} / \mathrm{inch}$. An intergranular mode was observed on samples tested in $50 \mathrm{ppm}$ chloride solutions and this type of cracking had a $\mathrm{K}_{\mathrm{ISCC}}$ value of $<5 \mathrm{ksi} / \mathrm{inch}$. For the binary alloy neither the fracture mode nor $\mathrm{K}_{\mathrm{ISCC}}$ was a strong function of the chloride content of the solution. A transgranular mode (not resembling the quasi-cleavage found in Mulberry) was observed in binary alloy samples tested in $<2 \mathrm{ppm}$ chloride solutions, and either a transgranular or a mixed transgranular plus intergranular mode was observed in samples tested in $50 \mathrm{ppm}$ chloride solutions. The $\mathrm{K}_{\mathrm{ISCC}}$ value for cracking in solutions of both chloride concentrations was approximately $15 \mathrm{ksi} / \mathrm{inch}$.

M-9

EFFECTS OF THE ENVIRONMENT ON THE CRACKING BEHAVIOR OF SELECTED URANIUM ALLOYS. N. J. Magnani. Report SC-R-722661. 1971. 9p. 
The uranium-base alloys U-7.5 wt $\%$ Nb-2.5 wt \% $\mathrm{Zr}, \mathrm{U}-4.5 \mathrm{wt} \% \mathrm{Nb}, \mathrm{U}-10$ wt \% Mo, and U-0.5 wt $\% \mathrm{Ti}$ were tested in several environments to determine their susceptibility to strèss corrosion cracking. The test environments ranged from $<10 \% \mathrm{RH}$ air and $100 \% \mathrm{RH}$ air for U-10 wt \% Mo to $<10 \% \mathrm{RH}$ air, $100 \% \mathrm{RH}$ air, pure gases $\left(\mathrm{O}_{2}\right.$, $\mathrm{N}_{2}, \mathrm{CO}_{2}, \mathrm{H}_{2}$ ), and aqueous solutions ranging from $<2$ to $500 \mathrm{ppm} \mathrm{Cl}^{-}$for U-7.5 wt \% $\mathrm{Nb}-2.5 \mathrm{wt} \% \mathrm{Zr}$. The results showed that all of the alloys stress corrosion cracked in laboratory air. Aqueous solutions containing chloride ions were more hostile to the alloys tested than laboratory air. From the results it is believed that transgranular cracking which has been observed in uranium alloys is caused by a twostage mechanical stress corrosion cracking mechanism involving either oxidation at the crack tip and then rupture of the film of the base material below the film or the adsorption of oxygen at the crack tip and then rupture of the weakened matrix material.

\section{M-10}

\section{EFFECT OF CHLORIDE IONS ON THE} CRACKING BEHAVIOR OF URANIUM-7.5 WEIGHT PERCENT NIOBIUM-2.5 WEIGHT PERCENT ZIRCONIUM AND URANIUM-4.5 WEIGHT PERCENT NIOBIUM. N. J. Magnani (SC). J. Nucl. Mater. 42:271-277. Mar 1972.

The effects of chloride ions on the stress corrosion cracking behavior of U-7.5 wt \% $\mathrm{Nb}-2.5$ wt $\% \mathrm{Zr}$ and $\mathrm{U}-4.5 \mathrm{wt} \% \mathrm{Nb}$ have been investigated utilizing a fracture mechanics approach to study the rate of crack propagation. The tests showed that chloride ion concentration strongly affects both the crack velocity and the fracture mode. The threshold stress in tensities for stress corrosion crack propagation for both alloys have been determined in aqueous solutions containing $<2 \mathrm{ppm}$ and $50 \mathrm{ppm} \mathrm{Cl}^{-}$. The threshold stress intensity for the U-7.5 wt \% $\mathrm{Nb}-2.5 \mathrm{wt} \% \mathrm{Zr}$ alloy in the $<2 \mathrm{ppm} \mathrm{\textrm {Cl } ^ { - }}$ solution was $15 \mathrm{ksi} \cdot \mathrm{in}^{1 / 2}$ while in the $50 \mathrm{ppm} \mathrm{\textrm {Cl } ^ { - }}$ solution it was less than $5 \mathrm{ksi} \cdot \mathrm{in}^{1 / 2}$. The binary alloy has essentially the same stress intensity threshold in both solutions, 14 to $17 \mathrm{ksi} \cdot \mathrm{in}^{1 / 2}$. At the highest chloride levels tested (500 ppm) stress corrosion cracking was observed without the application of stress. This was attributed to corrosion product wedging.

\section{M-11}

\section{ELECTROCHEMICAL AND OTHER STUDIES OF A URANIUM ALLOY EXHIBIT- ING STRESS-CORROSION CRACKING.} J. S. Bullock IV and J. B. Condon. Report Y-1821. Feb 29, 1972. 97p.

Experiments have been carried out to characterize the electrochemistry and stress-corrosion-cracking properties of a uranium-7.5 wt \% niobium-2.5 wt $\%$ zirconium alloy. Potential variations were detected on the surface of the alloy, and anodic currents were induced in air-equilibrated moisture films on the alloy. Electrochemistry of the stress-corrosion attack was found to be similar to the electrochemistry of the metal having no oxide film. Chloride ions accelerated stresscorrosion cracking apparently because of their ability to penetrate the oxide film on this alloy. Cold-worked alloy was resistant to stress-corrosion cracking, and the stress-corrosioncracking mechanism was unrelated to a pittingreaction mechanism.

\section{M-12}

\section{REACTION OF WATER VAPOR WITH URANIUM-7.5 WEIGHT PERCENT NIOBIUM- 2.5 WEIGHT PERCENT ZIRCONIUM AND URANIUM-4.5 WEIGHT PERCENT NIOBIUM.}

\section{N. J. Magnani and H. Romero. Report} SC-RR-720635. Sep 1972. 15p.

Coupons of U-7.5 wt \% Nb-2.5 wt \% $\mathrm{Zr}$ and $\mathrm{U}-4.5 \mathrm{wt} \% \mathrm{Nb}$ were exposed to water saturated nitrogen and oxygen to determine the rate of water vapor with the alloys. The data showed that the alloys reacted more slowly than uranium and that oxygen inhibited the reaction. Stress corrosion tests were also conducted to determine the effects of the environments on the cracking behavior. In moist environments the data showed that the ternary alloy does not stress corrosion crack in nitrogen but cracks readily in air while the binary alloy cracks with equal ease in both environments. 


\section{$\underline{\mathbf{N}}$}

\section{METALLOGRAPHIC TECHNIQUES AND MICROSTRUCTURES}

N-1

ELECTRON METALLOGRAPHY OF URANIUM AND SOME URANIUM ALLOYS.

I. T. Porter and J. C. Ruckman. Report AWRE-0-52/68. Sep 1968. 19p.

The production of thin foils of uranium and some of its alloys by electro-polishing was investigated in order that the microstructural aspects of stress corrosion cracking of these materials might be studied by transmission electron microscopy. For good transmission electron microscopy, the foil thickness was required to be less than $2000 \AA$. A literature survey revealed several investigations into the thinning of uranium, but little information on the thinning of the U-Mo and U-Nb-Zr alloys, which were of greatest interest. It was decided therefore to investigate the solutions used to thin uranium and, if possible, to apply these to the thinning of the alloys.

\section{N-2}

METHOD OF PRODUCING FOILS OF MULBERRY FOR TRANSMISSION ELECTRON MICROSCOPY. F. A. Greulich. Report SC-DR-69-185. June 1969. 16p.

Results of a study to determine methods of producing foils of $\mathrm{U}-7.5 \% \mathrm{Nb}-2.5 \% \mathrm{Zr}$ alloy to be used for transmission electron microscopy are presented. Suitable foils were produced by spark cutting and spark planing followed by final thinning in a dual jet thinner using a solution of $6 \% \mathrm{HCl} \mathrm{O}_{4}$ in methanol. A chemical etch-polishing solution, consisting of $35 \mathrm{ml}$ $\mathrm{HCl}, 25 \mathrm{ml} \mathrm{H}_{2} \mathrm{O}, 5 \mathrm{ml} \mathrm{HNO}_{3}$, and $1 \mathrm{ml} \mathrm{(25}$ drops) $\mathrm{HF}$, has also been developed for intermediate thinning to replace spark planing for faster preparation of gamma phase material.

\section{N-3}

MICROPROBE ANALYSIS OF FRACTURES. W. Estill (SCL). Proceedings of Second Annual Technical Meeting 85-88. International Metallographic Society, Inc., San Francisco, California. Sep 8-10, 1969, J, H, Bender, Ed.
Los Alamos, New Mexico, International Metallographic Society, Inc. 1970.

A new method for identifying small particles in fractured surfaces is described. The capability of the method is illustrated by an analysis of a uranium alloy.

$\mathrm{N}-4$

CATHODIC VACUUM ETCHING OF URANIUM ALLOYS. J. B. Duran and R. E. Fisher (SC). Microstructures 2:23-24. Oct-Nov 1971.

A metallographic technique for cathodic vacuum etching isothermally treated uranium alloys is described. Details of the procedure and a comparison between cathodic vacuum and electrolytic etching are given.

N-5

ANALYTICAL APPLICATIONS OF ELECTRON OPTICAL INSTRUMENTATION. J. E. Ferguson. Report Y-DA-4818. Aug 28, 1972. $11 p$.

The use of transmission electron microscopy (TEM), scanning electron microscopy (SEM), and electron probe micro-analysis for various types of material characterizations, particularly microchemical analysis of small specimens and small areas of specimens, is discussed. Examples of recent studies that demonstrate the microanalytical application of these disciplines are given. Results of SEM fractographic study of uranium-7.5 wt \% niobium- 2.5 wt \% zirconium alloy are given.

$\underline{\mathbf{0}}$

INCLUSION AND IMPURITY EFFECTS (HYDROGEN)

0-1

CREVICE CORROSION OF URANIUM AND

URANIUM ALLOYS. J. W. Frank and A. H. Roebuck. Report ANL-5380. Mar 1955.

Declassified Mar 1, 1957. 39p.

Three types of experiments were undertaken in order to study the corrosion of $U$ and $U$ alloys (including U-Nb-Zr) in high-temperature $\left(500^{\circ} \mathrm{C}\right.$ ) water. Results of the capsule and bonded 
plate-pin hole experiments showed that corrosion of enclosed $U$ is markedly different from that of $\mathrm{U}$ in open contact with $\mathrm{H}_{2} \mathrm{O}$. The gaseous hydriding experiments showed a definite relationship between rate of reaction and temperature, gas pressure, and alloy reacting.

0-2

THE HIGH-TEMPERATURE AQUEOUS CORROSION RESISTANCE OF THE URANIUM-5 PERCENT ZIRCONIUM-1.5 PERCENT NIOBIUM ALLOY. J. E. Draley, S. Greenberg, and W. E. Ruther (ANL). J. Electrochem. Soc. 107:732-740. Sep 1960.

The U-5\% Zr-1.5\% Nb alloy showed good corrosion resistance, as gamma quenched, in water to about $315^{\circ} \mathrm{C}$. Optimum heat treatment resulted in a rate of about $6 \mathrm{mg} / \mathrm{cm}^{2} /$ day at $290^{\circ} \mathrm{C}$. Moderate aging, e.g., $400^{\circ} \mathrm{C}$ for 2 hours, resulted in reduced corrosion rates in the initial stages of corrosion; however, corrosion resistance could be destroyed by overaging. After protracted exposure, samples failed. This was believed due to absorbed corrosion product hydrogen.

\section{0-3}

NONMETALLIC INCLUSIONS IN URANIUM ALLOYS WITH ZIRCONIUM, NIOBIUM, AND MOLYBDENUM. Yu. S. Virgel'ev. Stroenie Splavov Nekotorykh System s Uranom i Toriem 307-311. Moscow, Gosatomizdat, Russia. 1961.

Metallographic identification of nonmetallic inclusions in $\mathrm{U}$ alloys with $\mathrm{Zr}, \mathrm{Nb}$, and $\mathrm{Mo}$ indicates the presence of uranium carbide in U-Mo alloys, $\mathrm{NbC}$ in U-Mo-Nb alloys, and $\mathrm{ZrC}$ in zirconium containing alloys.

\section{0-4}

METALLOGRAPHY OF MULBERRY. H. Romero (SC). Proceedings of the Fourth Annual Technical Meeting 275-281. James L. McCall, Ed. Northglenn, Colorado International Microstructural Analysis Society, Inc. 1972.

The metallography of Mulberry was studied in this investigation to show the microstructural differences between two heats of material. The metallography shows a significant variation in the content of small unidentified freckle inclusions between the two heats of Mulberry. No other differences were observed.

\section{$\underline{\mathbf{P}}$ \\ CRYSTALLOGRAPHY, DEFORMATION, AND TEXTURES}

P-1

GLASS-METAL ENVELOPE FOR HIGH VACUUM X-RAY IRRADIATION OF SPECIMENS AT ELEVATED TEMPERATURES. C. A.W. Peterson and W. J. Steele. Report UCID-15254. Jan 31, 1968. 20p.

Description of a high-vacuum tube for X-ray irradiation of specimens at elevated temperatures is presented. The X-ray diffraction data, obtained using the tube, are presented for a Mulberry alloy at 150 to $573^{\circ} \mathrm{C}$.

P-2

YIELD SURFACE OF A URANIUM-7.5 WEIGHT PERCENT NIOBIUM-2.5 WEIGHT PERCENT ZIRCONIUM ALLOY (MULBERRY). D. D. Hays. Report BNWL-1112. Aug 1969. 34p.

The biaxial yield surface of a gamma stabilized uranium-7.5 wt \% Nb-2.5 wt \% $\mathrm{Zr}$ alloy (Mulberry) was determined. The yield surface is best described by the maximum strain (Von Mises) theory of yielding.

P-3

THE LOW STRAIN TENSILE BEHAVIOR OF MULBERRY ALLOY (7.5 PERCENT NIOBIUM, 2.5 PERCENT ZIRCONIUM, BALANCE URANIUM). C. E. Albright. Report SC-RR-70-407. July $1970.45 p$.

The stress-strain response of polycrystalline, $\boldsymbol{\gamma}$-quenched Mulberry alloy (uranium, 7.5\% niobium, $2.5 \%$ zirconium) was studied as a function of strain rate and compared to equilibrium stress-strain tests performed by allowing the strain to reach a maximum value at incrementally increasing stresses. Equilibrium stress-strain tests were also performed on samples prestressed to various values. Sheet tensile specimens were held at various states of strain in an X-ray diffractometer to determine crystal 
structural changes during deformation. Prestressed tensile bars were sectioned and examined metallographically and with the X-ray diffractometer. Two linear regions were observed in the equilibrium stress-strain tests; a low stress region with a slope of 5.3 to $5.5 \times 10^{6} \mathrm{psi}$, and a region above 40,000 psi with a slope of $3.3 \times 10^{6} \mathrm{psi}$. Finite strain rates tended to increase both slopes. The diffractometer experiments yielded plots of lattice parameter versus strain which showed a shift from a bodycentered cubic structure of the $\gamma^{\mathrm{s}}$ phase, to a body centered tetragonal structure of the $\gamma^{0}$ phase between 1 and $3 \%$ deformation. A semiempirical equation was developed which describes the equilibrium stress-strain behavior of Mulberry in terms of a stress induced phase transformation.

\section{P-4}

ANOMALOUS MECHANICAL PROPERTIES OF URANIUM-7.5 WEIGHT PERCENT NIOBIUM-2.5 WEIGHT PERCENT ZIRCONIUM ALLOY. R. E. Oakes Jr. Report Y-1732. Sep 22, 1970. 36p.

Abnormal mechanical properties in uranium-7.5 weight percent niobium- 2.5 weight percent zirconium alloy (such as nonlinear elasticity, rubber-like amounts of "elastic" spring back, and large amounts of mechanical hysteresis) have been examined in uniaxial tension and compression with respect to stress, strain, and aging. The results of these mechanical tests indicate the occurrence of a stress-induced phase transformation in both the as-quenched and aged alloy. Volumetric, resistance, and the microstructural changes which occur under stress in the alloy further substantiate the occurrence of such transformation.

\section{P-5}

LOW STRAIN TENSILE BEHAVIOR OF URANIUM-7.5 WEIGHT PERCENT NIOBIUM2.5 WEIGHT PERCENT ZIRCONIUM. C. Albright and C. Stein (SC). Met. Trans. 3:2217-2223. Aug 1972.

The stress-strain response of polycrystalline, $\gamma$-quenched U-7.5 wt \% Nb-2.5 wt \% $\mathrm{Zr}$ alloy was studied as a function of strain rate and compared to equilibrium stress-strain tests performed by allowing the strain to reach a maximum value at incrementally increasing stresses. Equilibrium stress-strain tests were also performed on prestressed samples. Sheet tensile specimens were held at various states of strain in an X-ray diffractometer to determine crystal structural changes during deformation. Prestressed tensile bars were sectioned and examined metallographically and with the $\mathrm{X}$-ray diffractometer. Two linear regions were observed in the equilibrium stress-strain tests: a low stress region with a slope of 5.3 to $5.5 \times 10^{6}$ psi, and a region above 40,000 psi with a slope of $3.3 \times 10^{6}$ psi. Finite strain rates tended to increase both slopes. The diffractometer experiments yielded plots of lattice parameter vs strain which showed a shift from a bcc structure of the $\gamma^{\mathrm{s}}$ phase, to a bct structure of the $\gamma^{0}$ phase between 1 and $3 \%$ deformation. It is postulated that this is a thermoelastic martensite transformation. A semiempirical equation was developed which describes the equilibrium stressstrain behavior of this alloy in terms of a stress induced phase transformation.

\section{$\mathbf{Q}$ \\ ELECTRICAL, OPTICAL, AND MAGNETIC PROPERTIES}

Q-1

\section{EFFECT OF IRRADIATION ON THE ELECTRIC CONDUCTIVITY OF URANIUM ALLOYS CONTAINING ZIRCONIUM AND NIOBIUM.}

M. V. Raetskii, A. Ya. Zavogodnii, and L. I. Gomozov. At. Energ. (USSR) 29:379-380. Nov 1970. (In Russian).

Study of a uranium alloy containing 8 at $\% \mathrm{Zr}$ and 12 at $\% \mathrm{Nb}$ indicated that the equilibrium transition temperature of this alloy to the $\gamma$ state $\left(660^{\circ} \mathrm{C}\right)$ is higher than that of an alloy containing 20 at \% Mo. The test specimens were subjected to homogenizing annealing at $1100^{\circ} \mathrm{C}$ and were quenched in water from $800{ }^{\circ} \mathrm{C}$, resulting in a homogeneous tetragonal distorted $\gamma^{0}$ phase. They were then exposed in the SM-2 reactor to integral fluxes of $\Phi_{1}=3 \times 10^{20}$ thermal neutrons $/ \mathrm{cm}^{2}$ at $70^{\circ} \mathrm{C}$ and $\Phi_{2}=9 \times 10^{20}$ $\mathrm{n} / \mathrm{cm}^{2}$ at $200^{\circ} \mathrm{C}$. 
After the irradiation, the electrical resistivity was determined potentiometrically in the temperature range from -196 to $+100^{\circ} \mathrm{C}$ with an accuracy of $\sim 2 \%$. It was found that the mean temperature coefficient of the resistivity, which was negative for the original alloy, increased as a result of the irradiation. After exposure to $\Phi_{2}$, it became positive, whereas the specific resistivity decreased at $-196{ }^{\circ} \mathrm{C}$ and increased at $+100^{\circ} \mathrm{C}$ with the dose. Change of the temperature dependence of the resistivity as a result of the phase change of the unirradiated uranium alloy containing $\mathrm{Zr}+\mathrm{Nb}$ was determined on specimens cooled from the homogenized state at $800^{\circ} \mathrm{C}$ by quenching in water, and on specimens annealed at $500^{\circ} \mathrm{C}$. The mean temperature coefficient of the alloy increased as the cooling rate decreased. The results indicated that the alloys are decomposed by irradiation. Fission of the uranium thus not only aids homogenization but generates decomposition centers and accelerates the decomposition of unstable alloys.

Q-2

ELECTROCHEMISTRY OF URANIUM AND URANIUM ALLOYS IN AQUEOUS SOLUTIONS. G. H. Jenks. Report ORNL-4651. June 1971. 149p.

Certain aspects of the corrosion of uranium and uranium alloys were investigated as part of an effort to understand and control the corrosion of these materials in aqueous solutions at normal ambient temperatures. The principal part of the work consisted of experimental electrochemical studies of corrosion of uranium and of the alloy U-7.5 Nb-2.5 $\mathrm{Zr}$ at $25^{\circ} \mathrm{C}$. The principal objective was providing an outline of the electrochemistry of these materials in the absence of aggressive anions. The solutions were primarily $0.1 \mathrm{M} \mathrm{K}_{2} \mathrm{SO}_{4}$ at $\mathrm{pH} 5$ to 10 and 0.1 and $1 \mathrm{~N} \mathrm{H}_{2} \mathrm{SO}_{4}$. A few pitting experiments were made with the alloy in solutions containing chloride in addition to $0.1 \mathrm{M} \mathrm{K}_{2} \mathrm{SO}_{4}$ and in solutions of $0.1 \mathrm{~N} \mathrm{HCl}$ and $0.1 \mathrm{~N} \mathrm{KCl}, \mathrm{pH} 8.7$. Gas atmospheres employed were: $4 \mathrm{H}_{2}: 96$ $\mathrm{Ar}, 20 \mathrm{O}_{2}: 80 \mathrm{Ar}$. The potentials investigated ranged from $<-1$ to $5 \mathrm{~V}$ versus SCE. Most of the polarizations were carried out potentiostatically but some were conducted galvanostatically. In either case current or potential values were recorded when judged to be within 5 to $10 \%$ of the steady-state value. Reviews and analyses of literature information pertaining to the electrochemistry of uranium corrosion in aqueous environments below $100^{\circ} \mathrm{C}$ and pertaining to certain electrochemical aspects of pitting, crevice corrosion, and stress corrosion cracking are presented.

\section{$\underline{\mathbf{R}}$}

\section{THERMAL, DIMENSIONAL, AND THERMODYNAMIC PROPERTIES}

\section{R-1}

GRAY, A THREE-PHASE EQUATION OF STATE FOR METALS. E. B. Royce. Report UCRL-51121. Sep 3, 1971. 49p.

A three-phase equation of state for metals was developed, based on the following assumptions: the entropy of melting is independent of pressure; the temperature dependence of the specific heat in the liquid is a universal curve, scaled on the melting temperature; the pressure dependence of the melting temperature is given by a modified Lindemann law; and the liquidvapor region may be described by a hard-sphere model perturbed by a van der Waals attraction. The equation of state is laid out in a $P(V, E)$ form for use in numerical hydrodynamics calculations, and parameters are given for $\mathrm{Be}$, $\mathrm{Mg}, \mathrm{Al}, \mathrm{Ti}$, stainless steel, $\mathrm{Ni}$, Monel, $\mathrm{Cu}, \mathrm{Nb}$, $\mathrm{Ta}, \mathrm{W}, \mathrm{Au}, \mathrm{Pb}, \mathrm{Th}, \mathrm{U}-7.5 \mathrm{Nb}-2.5 \mathrm{Zr}$, and $\mathrm{U}$. Experimental evidence for the validity of the equation of state is presented.

\section{R-2}

FLEXURE MEASUREMENTS ON A URANIUMNIOBIUM-ZIRCONIUM ALLOY DURING OXIDATION AND TEMPERATURE CYCLING.

R. E. Pawel and J. V. Cathcart (ORNL). J. Electrochem. Soc. 118:1776-1781. Nov 1971.

As part of a general program to study the fundamental oxidation characteristics of a uranium-7.5 wt \% niobium-2.5 wt \% zirconium alloy, measurements of the flexure of thin specimens reacting on one side were utilized to assess the extent of stress generation during oxidation. During the early stages of the reaction at $700^{\circ} \mathrm{C}$, 
rapid flexing of specimens was observed. Because the depth or thickness of the layer involved in this reaction was small, the stress within this zone must have been large to account for the observed bending stresses. The model relating flexure to a uniform stress in the growing oxide film appeared to be applicable and led to film stress values of the order of $10^{6} \mathrm{psi}$. When the oxidation process was interrupted, the high stresses then dissipated rapidly as the reaction. slowed. This behavior was analyzed in terms of a balance between stress generation and relief in both the oxide film and the substrate metal. Flexure measurements were also used during thermal cycling of these specimens to study the kinetics of the structural transformations exhibited by this alloy. The presence of an elastic stress gradient was found necessary to promote significant flexure during the transformation period in these specimens, suggesting that shear forces play an important role in the transformations, particularly in those involving the $a^{\prime \prime}$ structure.

\section{$\underline{\mathbf{S}}$}

\section{DIFFUSION}

\section{S-1}

\section{PENETRATION OF URANIUM FROM A URANIUM-NIOBIUM-ZIRCONIUM ALLOY} INTO MOLYBDENUM BY DIFFUSION. G. B. Fedorov and F. I. Khomov. Met. i Metalloved. Chistykh Metal., Sb. Nauchn. 64-68. Rabot, Russia. 1963.

The interaction between Mo and a $\mathrm{U}$ alloy containing $25 \% \mathrm{Nb}$ and $5 \% \mathrm{Zr}$ was investigated. Two samples of Mo in the form of tablets $10 \mathrm{~mm}$ in diameter and $6.8 \mathrm{~mm}$ high and a sample of the $U$ alloy of the same dimensions inserted between them were placed in a tubular Mo container and annealed in an evacuated quartz ampoule filled with Ar at 900 to $1200^{\circ} \mathrm{C}$. A grayish-yellow film a few hundredths of a millimetre thick formed on the contact surface of the Mo samples. The presence of the intermediate phase $\mathrm{ZrMO}_{2}$ was established by X-ray diffraction. Matako's method was used to calculate the activation energy of diffusion of $U$ out of the alloy and into Mo, which was found to be $46 \mathrm{kcal} / \mathrm{g}$-atom, and preexponential factor, which was found to be equal to $5 \times 10^{-4}$ $\mathrm{cm}^{2} / \mathrm{sec}$.

\section{S-2}

\section{DIFFUSION PROPERTIES OF URANIUM-} ZIRCONIUM-NIOBIUM ALLOYS. G. B. Fedorov, E. A. Smirnov, and V. N. Gusev. At. Energ. (USSR), 27:149-150. Aug 1969. (In Russian.)

Diffusion properties of $\mathrm{U}-\mathrm{Zr}-\mathrm{Nb}$ alloys were studied across the section of $\mathrm{C}_{\mathrm{Zr}}: \mathrm{C}_{\mathrm{Nb}}=1: 1$ (at \%) using radioactive ${ }^{235} \mathrm{U},{ }^{95} \mathrm{Zr}$, and ${ }^{95} \mathrm{Nb}$ isotopes. Data obtained showed that uranium alloying with equal amounts (at \%) of $\mathrm{Zr}$ and $\mathrm{Nb}$ reduced the diffusion mobility and increased the activation diffusion energy of ${ }^{235} \mathrm{U},{ }^{95} \mathrm{Zr}$, and ${ }^{95} \mathrm{Nb}$ (with the maximum activation energy and minimum diffusion factor) found in compounds containing from 60 to 70 at \% of alloying materials. It was also postulated that the mechanism for uranium, zirconium, and niobium diffusion was identical to the solid solution replacement mechanism.

\section{S-3}

DIFFUSIVE AND THERMODYNAMIC PROPERTIES OF $\gamma$-PHASE URANIUMNIOBIUM ALLOYS. G. B. Fedorov, E. A. Smirnov, and V. N. Gusev. At. Energ. (USSR) 32:11-14. Jan 1972. (In Russian.)

The ${ }^{235} \mathrm{U}$ and ${ }^{95} \mathrm{Nb}$ diffusion in uranium-niobium alloys was studied by the sectioning method. The measurements were carried out within the temperature range of 930 to $1900^{\circ} \mathrm{C}$. Niobium alloying of uranium considerably reduces the coefficients of diffusion. On the basis of the data obtained in this work and earlier data, the coefficients isolines and the isolines of the activation energies of diffusion in the uraniumniobium-zirconium system at $1100^{\circ} \mathrm{C}$ were drawn. Thermodynamic properties of the uranium-niobium system alloys were examined by measuring the electromotive force of the elements in the temperature range 750 to $900^{\circ} \mathrm{C}$, using as one of the electrodes the uranium alloys with $\mathrm{Nb}$ contents of $5,11.7,20,32,47,72$, and $87 \%$. 
$\underline{T}$

\section{CONSTITUTIONAL DIAGRAMS}

T-1

\section{CONSTITUTION OF THE URANIUM-RICH URANIUM-NIOBIUM AND URANIUM- NIOBIUM-ZIRCONIUM SYSTEMS. Final} Report-Metallurgy Program 3.1.5. A. E. Dwight and M. H. Mueller. Report ANL-5581. Oct 1957. $74 \mathrm{p}$.

The uranium-niobium-zirconium ternary system exhibits a continuous series of solid solutions at high temperatures. Miscibility gaps in the uranium-niobium and uranium-zirconium binary systems close with addition of the third element. Addition of both zirconium and niobium stabilizes the body-centered cubic gamma phase to lower temperatures. The $\beta$-uranium phase is eliminated in ternary alloys of $4 \mathrm{wt} \% \mathrm{Nb}$ or more. The $\delta$ phase of the uranium-zirconium binary system extends into the ternary system to no more than $10 \mathrm{wt} \% \mathrm{Nb}$. Over the major portion of the uranium-rich corner of the ternary system the equilibrium phases are $a-\mathrm{U}$ and $\gamma$ solid solution. The uranium-niobium binary system is the more comminatory of the limiting systems. No new ternary phases were found. The relation of microstructures to irradiation stability is discussed. The relation of lattice strain to limits of solid solubility is also discussed.

T-2

\section{PHASE DIAGRAMS OF CERTAIN TERNARY SYSTEMS OF URANIUM AND THORIUM.} O. S. Ivanov and T. A. Badajeva (Academy of Sciences, USSR). Report A/CONF.15/P/2043. $39 p$.

The results of investigation of alloy structures and phase diagrams of certain ternary systems, including uranium, thorium, and their refractory compounds, which are of interest in the search for materials for reactor fuel elements are presented. The general regularity governing the arrangement of typical crystal lattices of metals in the periodic table hold for equilibrium of binary solid solutions based on the $a, \beta$, and $a$ modifications of uranium much the same as the binary systems of titanium, iron, and other polymorphous metals. Phase diagrams of ternary systems U-Cr-Mo, U-Zr-Nb, U-Zr-Mo, $\mathrm{U}-\mathrm{Nb}-\mathrm{Mo}$, and isothermic tetrahedrons for 800 and $1000{ }^{\circ} \mathrm{C}$ of the quaternary system U-Zr-Nb-Mo are given to characterize the structure of most important alloys of uranium with the metals notable for their high solubility in $\gamma$ uranium and low thermal neutron cross sections. Some regularities of the existence of $\gamma$ solid solutions observed in these alloys are due to physical and chemical properties of their components and to the nature of their interaction.

\section{T-3}

FINAL REPORT [ON MISCIBILITY GAPS. IN NIOBIUM-URANIUM AND NIOBIUMURANIUM-ZIRCONIUM SYSTEMS] .

Fulmer Research Institute, Ltd. Stoke Poges, Bucks, England. Report NP-8237 and R-126/4. 1959. 94p.

The miscibility gap in the U-Nb system has been established using metallographic and X-ray techniques. The monotectoid temperature is placed at $640^{\circ} \mathrm{C}( \pm 2)$ and the composition limits at that temperature are 65 to 70 at $\% \mathrm{Nb}$ and $17.5 \pm 1$ at $\% \mathrm{Nb}$. The 700,650 , and $600{ }^{\circ} \mathrm{C}$ isothermal sections of the U-Nb-Zr system have also been investigated. Each of the miscibility gaps present in the limiting binary sections was found to be closed by additions of the third element. At $700{ }^{\circ} \mathrm{C}$ the $\mathrm{U}-\mathrm{Zr}$ gap is closed by addition of less than 5 at $\% \mathrm{Nb}$. The behavior of the $\mathrm{Zr}-\mathrm{Nb}$ gap is less certain owing to the sluggish reactions close to this binary system but the gap appears to be closed by about 15 at \% U. The U-Nb gap has been studied in more detail and is closed by 14 at $\% \mathrm{Zr}$. To a near approximation the ternary U-Nb gap can be considered to be bounded by the composition lines 33 at $\% \mathrm{U}$, 14 at $\% \mathrm{Zr}$, and about 20 at $\% \mathrm{Nb}$ depending on temperature. A notable feature is that at $\mathrm{Nb}$ and $\mathrm{Zr}$ compositions approximately corresponding to a line of minimum lattice distortion, the $\gamma$ phase at $600{ }^{\circ} \mathrm{C}$ bulges toward the $U$ corner. As a result of the closure of the gaps the $\gamma$ phase is stable over a large area of the diagram at temperatures down to at least $600^{\circ} \mathrm{C}$.

T-4 CONSTITUTION DIAGRAM OF URANIUMZIRCONIUM-NIOBIUM ALLOYS. RADIAL 
CROSS SECTION. O. S. Ivanov and L. I. Gomozor. Stroenie Splavov Nekotorykh System s Uranon i Toriem 93-106. Moscow, Gosatomizdat, Russia. 1961.

Phase diagrams were constructed for $\mathrm{U}-\mathrm{Nb}-\mathrm{Zr}$ alloys and the distribution of $\boldsymbol{\gamma}$-solid solutions at various temperatures and their stability with increasing temperatures or continuous tempering at $500{ }^{\circ} \mathrm{C}$ : were studied.

\section{T-5}

CONSTITUTION DIAGRAM OF URANIUMZIRCONIUM-NIOBIUM. CROSS SECTIONS WITH CONSTANT URANIUM CONTENT, AND POLYTHERMAL DIAGRAM OF THE SYSTEM. O. S. Ivanov and L. I. Gomozov. Stroenie Splavov Nekotroykh System S Uranom i Toriem 107-127. Moscow, Gosatomizdat, Russia. 1961.

Microstructure and X-ray diffraction analyses were made of 185 specimens annealed at various temperatures, and six polythermal constitution diagrams were constructed. At $1000^{\circ} \mathrm{C}$ uranium, zirconium, and niobium form continuous solid solutions. Thirteen monovariant and 3 nonvariant equilibria were formed at 685 , 645 , and $430{ }^{\circ} \mathrm{C}$. The dissociation regions $(\gamma+\gamma \mathrm{Zr}),(\gamma+\gamma \mathrm{Nb})$, and $(\gamma \mathrm{Zr}+\gamma \mathrm{Nb})$ taper off into ternary systems $(2.5,12.5$, and 21.5 at $\%$, respectively). The solubility of $\mathrm{Nb}$ in the $\delta_{1}$ phase does not exceed 2 at \%. The rapid tapering off in the dissociation regions is discussed.

\section{T-6}

STRUCTURE OF QUATERNARY URANIUMZIRCONIUM-NIOBIUM-MOLYBDENUM ALLOYS AT 1000 TO $800^{\circ} \mathrm{C}$. O. S. Ivanov and Yu. S. Virgil'ev. Stroenie Splavov Nekotorykh System s Uranom i Toriem 265-295. Moscow, Gostamoizdat, Russia. 1961.

Isothermal tetrahedrons were constructed for $\mathrm{U}-\mathrm{Zr}-\mathrm{Mo}-\mathrm{Nb}$ alloys at 1000 and $800^{\circ} \mathrm{C}$. It was found that in four component alloys the $\gamma$ solid solution phase is more stable than in limited ternary systems of U-Mo-Zr and U-Nb-Mo. In cross sections with 80,70 , and 60 at \% $\mathrm{U}$, the $\boldsymbol{\gamma} \rightarrow \boldsymbol{a}$ martensite transformation adjacent to $\mathrm{U}-\mathrm{Zr}$ is limited by alloying Mo and $\mathrm{Nb}$.
T-7

SOLIDUS AND LIQUIDUS OF THE URANIUMZIRCONIUM-NIOBIUM SYSTEM. T. A.

Badaeva, and R. I. Kuznetsova. Izv. A kad. Nauk SSSR, Metal 189-190. Mar-Apr 1971. (In Russian.)

Isotherms of the solidus and liquidus were constructed for the ternary system $\mathrm{U}-\mathrm{Zr}-\mathrm{Nb}$ using thermal analysis data. The presence of a continuous series of $\boldsymbol{\gamma}$-solid solutions was confirmed. Solidus and liquidus curves were partially constructed for the following binary systems: U-Zr, U-Nb, and $\mathrm{Zr}-\mathrm{Nb}$.

$\underline{\mathbf{U}}$

\section{CONTINUOUS COOLING TRANSFORMATIONS}

No references were found on this subject during the literature survey.

\section{$\underline{\mathbf{V}}$ \\ ISOTHERMAL TRANSFORMATIONS}

V-1

TRANSFORMATIONS IN URANIUM-BASE

ALLOYS. Summary Report [for] Dec 14, 1955-Mar 31, 1957. S. J. S. Parry, F. C. Holtz, and R. J. Van Thyne. Report ARF-2095-1. June 28, 1957. 195p. ARF Project B-095. (For Westinghouse Electric Corporation, Bettis Plant, Pittsburgh, Pennsylvania.)

Transformation kinetics of binary U-Nb and ternary U-Nb-base alloys were investigated. Additions included zirconium, chromium, titanium, silicon, nickel, ruthenium, and vanadium. Encapsulated samples were given a homogenization anneal at 1000 or $1100^{\circ} \mathrm{C}$, water-quenched from $900{ }^{\circ} \mathrm{C}$ to retain the $\gamma$ phase, and reheated to temperatures between 360 and $600{ }^{\circ} \mathrm{C}$. The metastability of the $\gamma$ phase was examined by metallographic, hardness, resistometric, dilatometric, and X-ray diffraction techniques. The U-Nb system is characterized by a monotectoid decomposition of the high temperature $\gamma$ allotrope at about $645^{\circ} \mathrm{C}$ to form $a$ and $\gamma_{2}$, a niobium-rich cubic structure. Decomposition of $\mathrm{U}-\mathrm{Nb}$ and in most $\mathrm{U}-\mathrm{Nb}-\mathrm{X}$ alloys occurred by a continuous precipitation of $a$ from the body-centered cubic $\gamma$ phase with a resultant enrichment in niobium of $\gamma$ until the equilibrium $\gamma_{2}$ composition was reached: 
In the U-Nb-Ti and U-Nb-V systems, $a$ and $\boldsymbol{\gamma}_{2}$ were coprecipitated. Annealing at 550 and $600^{\circ} \mathrm{C}$ produced decomposition products which, in most materials, orginated at the grain boundaries; a fine precipitate which initiated throughout the matrix was observed at lower annealing temperatures. Increasing the niobium content resulted in greatly increased stability. The following elements added to a U-Nb base were found to retard transformation of the $\gamma$ phase: zirconium, chromium, ruthenium, and vanadium. Additions of titanium, silicon, and nickel produced alloys which were less stable than the U-Nb base to which they were added. Cold-working a Uं-7 wt \% Nb-2 wt \% Zr composition caused a more rapid transformation upon annealing at 360 and $450^{\circ} \mathrm{C}$, and the resulting microstructures were different.

\section{V-2}

\section{BEHAVIOR OF URANIUM-ZIRCONIUM-} NIOBIUM ALLOYS IN ANNEÁLING AND

TEMPERING. L. I. Gomozov and O. S. Ivanov. Stroenie Splavov Nekotorykh System s Uranom $i$ Toriem 128-140. Moscow, Gosatomizdat, Russia. 1961.

Constitution diagram, hardness, and crystal structure studies of $\mathrm{U}-\mathrm{Zr}-\mathrm{Nb}$ alloys annealed at $1000{ }^{\circ} \mathrm{C}$ indicate $a$-saturated solid solutions with an $\boldsymbol{a}$-uranium base, $\boldsymbol{\gamma}^{\prime}$ solid solutions with tetragonal lattices, $\gamma$-solid solutions with cubic lattices, $a^{\prime}$-saturated solid solutions with an $a$-zirconium base, and metastable $\omega$-phase zirconium with hexagonal structure, as well as intermediate regions. $(a+\gamma),\left(a^{\prime}+\gamma^{\prime}\right)$, $(a \mathrm{Zr}+\omega)$, and $(\omega+\gamma)(\beta)$.

V-3

STABILITY OF ANNEALED GAMMA-SOLID SOLUTIONS IN URANIUM-ZIRCONIUMNIOBIUM-MOLYBDENUM ALLOYS AFTER CONTINUOUS ANNEALING AT 430 to $550^{\circ} \mathrm{C}$. O. S. Ivanov and Yu. S. Virgel'ev. Stroenie Splavov Nekotorykh System s Uranon i Toriem 296-306. Moscow, Gosatomizdat, Russia. 1961.

A complete transformation of $\boldsymbol{\gamma}$-phase solid solution was observed in alloys with 70 to 80 at $\% \mathrm{U}$ after 100 hours of quenching, further tempering only coagulated the disintegrated structure. Alloying with 40 to 50 at $\% \mathrm{Zr}$, Mo, and $\mathrm{Nb}$ slowed the transformation even after. 1000 hours of quenching.

V-4

DISINTEGRATION OF GAMMA-SOLID SOLUTION IN URANIUM-NIOBIUM AND URANIUM-ZIRCONIUM-NIOBIUM ALLOYS.

Yu. S. Virgel'ev and O. S. Ivanov. Stroenie $i$ Svoistva Splavov Urana, Toriya i Tsirkoniya. 109-115. Moscow, Gosatomizdat, Russia. 1963.

A tetragonal lattice was formed during tempering of Nb-rich binary U-Nb alloys. The short duration of the process during fast cooling and the low hardness of the lattice do not confirm a concept of the process as one of ordering. Decomposition of $\gamma$ solid solution $U$ with 15 to 27.8 at $\% \mathrm{Nb}$, caused by isothermal tempering at $500^{\circ} \mathrm{C}$, confirmed that an increase of $\mathrm{Nb}$ disturbs the homogeneous decomposition $\left(\gamma \rightarrow \gamma_{2}+a\right)$, producing a heterogeneous $\left(\gamma \rightarrow \gamma_{2}+a\right)$ and then $\left(\gamma_{1} \rightarrow \gamma_{2}+a\right)$ process. An increase of the total alloying content, replacement of zirconium by niobium, and an increase of the tempering temperature in ternary $\mathrm{U}-\mathrm{Zr}-\mathrm{Nb}$ alloys result in heterogeneous decomposition of $\boldsymbol{\gamma}$ solutions.

V-5

AGING MULTICOMPONENT SOLID SOLUTIONS ON URANIUM BASE. Yu. S. Virgel'ev. Stroenie i Svoistva Splavov Urana, Toriya i Tsirkoniya 217-222. Moscow, Gosatomizdat, Russia. 1963.

Aging tests of $\mathrm{U}$ base ( 70 at $\% \mathrm{U}$ ) $\mathrm{Zr}-\mathrm{Nb}$-Mo solid solutions additionally alloyed with $\mathrm{Cr}$ or $\mathrm{V}$ during isothermal annealing at $500{ }^{\circ} \mathrm{C}$ showed that additions of $\mathrm{Cr}$ or $\mathrm{V}$ increase aging effects, inhibit $\gamma$ stability, and cause faster disintegration at lower annealing temperatures.

\section{V-6}

ISOTHERMAL TRANSFÓRMATION STUDY OF SOME URANIUM-BASE ALLOYS. C. A. W. Peterson, W. J. Steele, and S. L. DiGiallonardo. Report UCRL-7824. Aug 1964. 28p.

Isothermal time-temperature-transformation characteristics are presented for the gamma phase of alloys of uranium with molybdenum, niobium, and zirconium (including $\mathrm{U}-\mathrm{Nb}-\mathrm{Zr}$ alloys). The changes in hardness and microstructure are described and correlated with the time, as 
determined by resistivity measurements, to initiate transformation at a given temperature.

\section{V-7}

KINETICS OF THE ISOTHERMAL TRANSFORMATION OF GAMMA SOLID SOLUTIONS OF SOME URANIUM ALLOYS. V. B.

Kishinevskii, A. A. Tret'yakov, L. I. Gomozov, and O.S. Ivanov. Fiziko-Khimiya Splavov $i$ Tugoplavkikh Soedinenii s Toriem $i$ Uranom, Izdatel'stvo Nauka 42-52. Moscow, Russia. 1968. 25p. (A translation by A. M. A. Mincer appears as UCRL-Trans-10452.)

The dilatometric method was used to construct diagrams of the isothermal transformation of the $\gamma$ phase for two ternary alloys of uranium with zirconium and niobium and for a binary uranium alloy containing 20 at $\%$ of niobium. The resulting $\mathrm{C}$-shaped curves consist of two branches, which indicates that the transformation occurs by different mechanisms at high and low temperatures. The rates of the transformation of the $\gamma$ phase in the binary uranium alloy containing 20 at $\% \mathrm{Zr}$ are very high. It has been shown by X-ray diffraction that the decomposition of the alloy with 20 at \% of $\mathrm{Nb}$ takes place via the formation of a metastable intermediate $\gamma_{1}$ phase with a subsequent formation of $\gamma \mathrm{Nb}$ phase. The decomposition is heterogeneous in the range of 500 to $600^{\circ} \mathrm{C}$. Partial replacement of the niobium by zirconium leads to the formation of a tetragonal $\gamma^{0}$ phase when the alloy is quenched, and on tempering this phase decomposes by a homogeneous mechanism. As a result of further alloying of the uranium with niobium and zirconium the quenched specimen contains a $\boldsymbol{\gamma}$ phase whose decomposition is heterogeneous.

V-8

A STUDY OF THE TIME-TEMPERATURE TRANSFORMATION BEHAVIOR OF A URANIUM-7.5 WEIGHT PERCENT NIOBIUM2.5 WEIGHT PERCENT ZIRCONIUM ALLOY. C. W. Dean. Report Y-1694. Oct 24, 1969. $101 \mathrm{p}$.

Thesis: Submitted to University of Tennessee, Knoxville.

The time-temperature-transformation behavior of the $\gamma$ phase of a uranium-7.5 weight percent niobium-2.5 weight percent zirconium alloy was determined for the temperature range from 200 to $800^{\circ} \mathrm{C}$. Metallography, microhardness, and $\mathrm{X}$-ray diffraction techniques were used to determine a time-temperature-transformation diagram. The diagram was found to consist of two overlapping $\mathrm{C}$ curves. The morphology of the transformation was: a lamellar structure above the upper nose, a fine precipitation of a-uranium platelets below this nose, and a Widmanstatten pattern which has its time-temperature relationship defined by the lower nose. The critical temperature was determined to be $650{ }^{\circ} \mathrm{C}$. Above this temperature, the body-centered cubic $\boldsymbol{\gamma}$ phase was stable.

Upon water quenching to room temperature, a transition phase, $\gamma \mathrm{s}$, was formed in which the body-centered atoms are slightly shifted. Upon aging, this phase transformed to $\gamma^{0}$, which is tetragonal. Further aging produced $a^{2}$ which has a monoclinic crystal structure and is observed metallographically as a Widmanstatten pattern. The hardness of the $a^{2}$ phase varied from 250 to over $600 \mathrm{DPH}$ when the material was completely transformed. Aging samples in water-saturated gases were found to significantly retard the beginning of the $\gamma$-phase decomposition. Under certain conditions, a substructure was: found to be visible.

\section{V-9}

KINETICS OF TRANSFORMATION OF THE GAMMA PHASE OF URANIUM-ZIRCONIUMNIOBIUM AND URANIUM-NIOBIUMMOLYBDENUM ALLOYS. L.I. Gomozov, V. A. Makhova, V. V. Gomov, and O. S. Ivanov. (Institute of Metallurgy, Moscow, Russia.) Fiz. Metal. Metalloved 33:307-314. Feb 1972. (In Russian.) (A translation of this report is SC-T-722548 by Sandia Laboratories, Albuquerque, New Mexico.)

Isothermal conversion of the $\gamma$-phase of solid solution at 500 to $630^{\circ} \mathrm{C}$ was investigated in the alloys U-Zr-Nb and U-Nb-Mo containing $85 \% \mathrm{U}$. Investigative methods included dilatometric, microstructure, and X-ray techniques. For the ternary $\mathrm{U}-\mathrm{Zr}-\mathrm{Nb}$ alloys when the composition of the resulting. $\gamma$-phase was relatively close to the original, decomposition proceeded homogeneously 
and in accordance with a single kinetic mechanism. Use of Abrami's formula gave $n=1$ to 2.2. The remaining alloys decomposed homogeneously in two stages, where the second stage (diffusion control) corresponded to the value $n=0.5$ to 0.8 . The alloy with the atomic $\%$ ratio $\mathrm{Zr}: \mathrm{Nb}=3: 1$ decomposed to a stable structure, apparently due to an equality of parameters of the initial and the generated $\gamma$ phase.

\section{$\underline{\mathbf{w}}$}

\section{MARTENSITIC PHASES}

W-1

SEVERAL MICROGRAPHIC ASPECTS OF URANIUM IN THE ALPHA PHASE BEFORE IRRADIATION. J. Lehmann and H. Aubert. Symposium on Special Metallurgy 41-46.

Held at Saclay, France. June 27-28, 1957. 130p: (In French.)

It is shown that it is possible to obtain in pure and weakly alloyed uranium, structures ranging from large grains to finer martensites. For some of these alloys, $\mathrm{Al}-\mathrm{U}$ and $\mathrm{Cr}-\mathrm{U}$, the transformation is produced by a germination mechanism and well-characterized growth. In Mo-U and $\mathrm{Nb}-\mathrm{U}-\mathrm{Zr}$ alloys, a clear martensite structure was observed.

W-2

CRYSTAL STRUCTURES OF TRANSITION PHASES FORMED IN URANIUM-16.60 ATOMIC PERCENT NIOBIUM-5.64 ATOMIC PERCENT ZIRCONIUM ALLOYS. H. L. Yakel (ORNL). J. Nucl. Mater. 33:286-295. Dec 1969.

Single crystal X-ray diffraction studies of $\boldsymbol{\gamma}$-quenched and aged alloys of uranium with 16.60 at \% ( $7.5 \mathrm{wt} \%)$ niobium and 5.64 at \% (2.5 wt \%) zirconium revealed two metastable transition phases whose structures were derived from small atom displacements from some of the sites occupied in the A2r structure. The phases appeared to be identical with those previously reported as having chemically ordered structures in $\gamma$-quenched uraniummolybdenum and uranium-niobium alloys. The first transition structure, $\boldsymbol{\gamma}^{\mathbf{S}}$, was formed on $\gamma$ quenching; it was cubic, space group $1 \overline{43} \mathrm{~m}$, with a unit cell parameter about twice that of the $\gamma$ phase. It may be formally described as eight unit cells of the $\boldsymbol{\gamma}$ structure in which the body-centered atoms have moved in correlated $\langle 100\rangle$ directions. On aging at 150 or $350^{\circ} \mathrm{C}$, these movements are further correlated along a particular [001] direction, producing the second transition structure $\boldsymbol{\gamma}^{\mathbf{0}}$; it is tetragonal, space group $\mathrm{P} 4 / \mathrm{nmm}$, with an atom arrangement similar to that reported for $\beta$-neptunium. No evidence was found to suggest significant chemical order in either transition structure.

\section{$\underline{\mathbf{X}}$ \\ IRRADIATION EFFECTS AND NUCLEAR PROPERTIES}

\section{$X-1$}

EFFECTS OF IRRADIATION ON SOME CORROSION-RESISTANT FUEL ALLOYS.

J. H. Kittel, S. Greenberg, S. H. Paine, and J. E. Draley (ANL). Nuclear Sci. and Eng. 2:431-449. July 1957.

Three corrosion-resistant uranium-base alloys, $\mathrm{U}-3$ wt $\% \mathrm{Nb}, \mathrm{U}-5$ wt $\% \mathrm{Zr}-1.5 \mathrm{wt} \% \mathrm{Nb}$, and $\mathrm{U}-3.8 \mathrm{wt} \% \mathrm{Si}\left(\mathrm{U}_{3} \mathrm{Si}\right)$ were irradiated to burnups of 0.1 at $\%$ or less. Observations were made of irradiation-induced length changes in specimens of the alloys as influenced by the method of fabrication and heat treatment, and of changes in aqueous corrosion resistance resulting from irradiation. It was found that the uraniumniobium alloy was unsuitable from the standpoint of dimensional and surface stability, and its corrosion resistance was destroyed by irradiation. The uranium-zirconium-niobium alloy could be nominally stabilized under irradiation, and its corrosion resistance was destroyed by between 0.046 and 0.074 at $\%$ burnup.

\section{X-2}

PROSPECTUS FOR IRRADIATIONS IN THE NRU J-16 LOOP. D. E. Thomas, R. H. Fillnow, and S. B. McRickard. Report WAPD-IPC-772. Dec 1957. Declassified Jan 3, 1958. 26p.

Previous irradiation tests on gamma-phase U-Nb indicate that irradiation experiments should be conducted with a wider range of compositions 
containing $\mathrm{Zr}$ which improves corrosion and radiation behavior. A new specimen design is described for use in the in-pile loop. Other equipment designs, test conditions, and procedures are described.

$\mathrm{X}-3$

\section{EFFECTS OF IRRADIATION ON CORROSION RESISTANCE OF SOME HIGH URANIUM}

ALLOYS. S. Greenberg and J. E. Draley (ANL). Nuclear Sci. Eng. 3:19-29. Jan 1958.

Three corrosion resistant $\mathrm{U}$ base alloys were corrosion-tested in high temperature water: $\mathrm{U}-5 \% \mathrm{Zr}-1.5 \% \mathrm{Nb}, \mathrm{U}-3 \% \mathrm{Nb}-0.5 \% \mathrm{Sn}$, and $\mathrm{U}-3.8 \% \mathrm{Si}$. Only the U-3.8\% Si alloy retained any degree of corrosion resistance after burnups in excess of 0.1 at \%. Low burnup did not adversely affect the corrosion resistance of the diffusion bond between $\mathrm{U}-2 \% \mathrm{Zr}$ alloy and its Zircalloy-2 cladding.

\section{$\mathrm{X}-4$}

THE EFFECTS OF RADIATION ON SOLIDS. Yu. N. Sokurskii. A tomnaya Energ. 6:403-425. Apr 1959. (In Russian.)

A review is given of reports presented at the Second International Conference on Peaceful Applications of Nuclear Energy (Geneva, 1958) on the effects of radiation on solids. Analysis is made of experimental work on the quantitative evaluation of the radiation-induced defects in materials and on the neutron radiation effects on fissionable uranium, plutonium, and their alloys. New data are presented on the effects of large burnup (up to 2 at $\%$ ) on the dimensions and shape of fabricated uranium and its alloys (including $\mathrm{U}-\mathrm{Nb}-\mathrm{Zr}$ alloys).

\section{X-5}

EFFECT OF IRRADIATION ON FUEL MATERIALS. PART II. J. H. Kittel and S. H. Paine (Argonne National Laboratory, Lemont, Illinois.) Nuclear Energy Engr. 357-360. July 1959.

Unalloyed uranium with suitable metallurgical treatment can be subjected to burnups of 2 at \%. Damage is severe. Deleterious changes occurring at moderate irradiation temperatures are principally due to surface roughing and anisotropic growth. Certain alloying conditions greatly refined the grain size in uranium, thus eliminating surface roughening. Alloying conditions can alter the transformation kinetics of uranium so that preferred orientation resulting from fabrication procedures may be largely removed by heat treatment. For alpha-phase alloys, these heat treatments usually consist of holding the material briefly in the gamma phase, followed by an extended isothermal anneal to permit the alloy to transform completely to alpha. For alloys retaining the gamma phase on cooling, the preferred heat treatment is usually a quench from the gamma phase, which may be preceded by a homogenizing anneal at gamma temperatures. Both uranium and uranium-base alloys show definite irradiation temperature limitations, above which swelling occurs. Thorium and thorium-uranium alloys show dimensional stabilities which are superior to those shown by the metallic uranium fuels. Oxide fuels are characterized by even better stability under irradiation. Pellets of $\mathrm{ThO}_{2}$ with additions of $\mathrm{UO}_{2}$ show negligible dimensional changes after burnups on the order of $1 \%$ of the metal atoms with central temperatures of $2000^{\circ} \mathrm{C}$ or more during irradiation.

\section{X-6}

ENGINEERING DECISIONS BASED ON IRRADIATION EXPERIMENTS. J. H. Kettel and S. H. Paine (ANL). Metal Progr.

76:119-122. Nov 1959.

A discussion is given on the importance of irradiation of experimental reactor parts prior to engineering design. Illustrations of these necessary experiments are discussed for the Daniel's Pile, Fast Breeder Reactor, Boiling Water Reactor, and Borax-IV. Radiation effects on U-Nb-Zr alloys are discussed.

X-7

STATISTICAL DATA ABOUT THE BEHAVIOR OF. FUEL PROVIDED FOR THE USE OF THE EL $_{3}$ REACTOR. J. A. Stohr. Report NAA-SRMemo-4596. Translated by K. Langrod and F. R. Bennett (Atomics International Division, North American Aviation, Inc., Downey, California). Paper presented at the Symposium on the Metallurgy of Nuclear Materials, Stockholm, Sweden. Oct 1959. 22p.

Capsules containing samples of U-1.5 Nb-4.5 Zr, U-10 Mo, U-2 Mo, U-3 Mo, and U-1.5 Mo alloys 
were irradiated in the $\mathrm{EL}_{3}$ reactor and examined periodically after increments of 400 megawattdays of energy per ton of $U$. Periodic radiographic examinations on the samples revealed no deformation of the alloy slugs, or loosening of cladding under the highest burnups (CENS, $\mathrm{EL}_{3}-$ Eau Loudre (heavy water) Reactor, Saclay, France).

\section{X-8}

\section{EFFECTS OF IRRADIATION ON THE EBWR FUEL ALLOY URANIUM-5 WEIGHT PERCENT ZIRCONIUM-1.5 WEIGHT PERCENT NIOBIUM. Final Report, Metallurgy Program 6.1.20. J. H. Kittel. Report ANL-5639. July 1960. 43p.}

Irradiations were made on small specimens of U-5 wt \% Zr-1.5 wt \% $\mathrm{Nb}$ alloy with a wide variety of fabrication histories and heat treatments in order to determine the optimum heat treatment for the fuel plates for the Experimental Boiling Water Reactor (EBWR). In the time available, a heat treatment could not be found which simultaneously conferred dimensional stability and corrosion resistance to the alloy. The most effective heat treatment for dimensionally stabilizing swaged or round-rolled material was a 24-hour isothermal transformation from the $\gamma$ phase at $650^{\circ} \mathrm{C}$. This heat treatment was subsequently used as a basis for the heat-treatment specifications for the EBWR fuel plates. In later studies on specimens cut from plates, it was learned that the alloy could be adequately stabilized against irradiation growth and also made corrosion-resistant by first reducing the plate $12 \%$ in thickness by cold rolling followed by a 24-hour isothermal transformation from the $\gamma$ phase at $665^{\circ} \mathrm{C}$, and finally quenching from $800^{\circ} \mathrm{C}$. Irradiation growth rates of plate specimens were effectively reduced by the presence of metallurgically bonded Zircaloy- 2 cladding. Flat-rolled material under irradiation generally increased in length and width and decreased in thickness.

\section{X-9}

EXAMINATION OF EBWR CORE-1A FUEL. R. Carlander. Report ANL-6832. June 1966. $15 p$.

An EBWR fuel element (U-Nb-Zr alloy) was examined, after operation at $100 \mathrm{MW}$ and a maximum burnup of 0.61 at \%, as part of a continuing evaluation of the in-reactor performance and irradiation damage to the fuel alloy. Although the maximum rate of volume increase per at \% burnup was $7.6 \%$ at the point of maximum burnup, increases as high as $13.3 \%$ per at \% burnup were found in regions of lower burnup. These larger rates of volume increase were due to a combination of burnup and high centerline fuel temperature. Large-scale buildups, particularly in regions free of nucleate boiling, contributed to the higher centerline fuel temperatures by acting as a thermal insulation barrier between the cladding and the water coolant. The temperatures, which were calculated to be in excess of $500^{\circ} \mathrm{C}$, resulted in an annealing out of the residual stresses that existed in the fuel elements before the MW 100 operation. The results indicated that for satisfactory performance at high power levels, the centerline fuel temperature of fuel elements of the EBWR type should be maintained below $500^{\circ} \mathrm{C}$ through the adequate control of scale accumulation.

\section{$\mathrm{X}-10$}

DEVELOPMENT OF LOW-ALLOY TERNARY URANIUM ALLOYS (URANIUM-NIOBIUMCHROMIUM, URANIUM-NIOBIUM-IRON, URANIUM-NIOBIUM-NICKEL, URANIUMNIOBIUM-SILICON, URANIUM-NIOBIUMZIRCONIUM). M. R. Bastelli, C. D'Amato, R. Renzoni, F. S. Saraceno, and T. B. Wilson. (Societa Nazionale Metanodotti, Milan, Italy. Laboratori Reuniti Studi e Richerche). Report EUR-4384. July 3, 1969. 100p. (In Italian.) [A translation of this report is ORNL-tr-2325.]

Studies were made on the development of ternary uranium alloys whose irradiation behavior would, if possible, be better than that of U-1\% Mo alloys. The work on the U-Nb-X ternary alloys included studies on beta-quenched and tempered $\mathrm{U}-1 \% \mathrm{Nb}-0.15$ to $0.25 \% \mathrm{Cr}$ alloys. Laboratory tests showed that these alloys have good structural stability at $550^{\circ} \mathrm{C}$, better mechanical resistance in the cold and in the hot $\left(550^{\circ} \mathrm{C}\right)$ state than that of traditional alloys, and better thermal cycling resistance $\left(0\right.$ to $\left.550^{\circ} \mathrm{C}\right)$. Creep resistance was higher when the chromium content was low $(0.15 \% \mathrm{Cr})$. The $\mathrm{U}-1 \% \mathrm{Nb}-0.15 \%$ $\mathrm{Cr}$ alloy is to be subjected to in-pile irradiation. 
$\underline{\mathbf{Y}}$

\section{FUEL ELEMENT APPLICATIONS AND PROPERTIES}

Y-1

DESIGN CRITERIA-HRT (HOMOGENEOUS

REACTOR TEST) PRESSURIZATION

CONTROL. M. I. Lundin. Report CF-56-4-55. Apr 10, 1956. Declassified Mar 16, 1957. 8p.

Information of phase diagrams, corrosion, heat treatment, and hardness of $\mathrm{U}-\mathrm{Nb}-\mathrm{Zr}$ alloys is included in this report.

$\mathbf{Y}-2$

PROPOSAL FOR A FUEL MATERIAL TEST IN THE CR-VI LOOP IN THE NRX REACTOR, EXPERIMENT CR VI-2. P. C. Daly. Report WAPD-IPC-256 and Addendum. [Aug 1956.] Declassified Mar 19, 1957. Addendum Declassified Mar 20, 1957. 14p.

The addendum to this report was originally issued as WAPD-IPC-308. The test procedure to be used at NRX Reactor on U-Nb and $\mathrm{U}-\mathrm{Nb}-\mathrm{Zr}$ fuel elements with defects in the Zircaloy-2 cladding is described.

\section{Y-3}

MANUFACTURE. OF FUEL PLATES FOR THE EXPERIMENTAL BOILING WATER REACTOR.

R. E. Macherey, C. H. Bean, N. J. Carson, Jr., and J. R. Lindgren. Report ANL-5629. June 1957. 250p.

The Experimental Boiling Water Reactor (EBWR) constructed on the site of the Argonne National Laboratory (ANL), is currently fueled with an uranium alloy containing $5 \mathrm{wt} \% \mathrm{Zr}$ and $1.5 \mathrm{wt} \%$ $\mathrm{Nb}$. The fuel is in the form of plates in tegrally clad with Zircaloy- 2 by roll bonding and is divided into two isotopic concentrations, natural uranium and uranium enriched to the extent of $1.44 \%{ }^{235} \mathrm{U}$. The plates are in two thicknesses, 0.210 and 0.273 inches, with the width and length of all plates being 3.62 and 54 inches, respectively. The manufacturing practice used in the production of approximately 1100 plates, of which 888 were required to completely load the reactor, is described. Discussed in the paper are the production of the uranium fuel alloy, the fabrication of the cladding components from Zircaloy-2 ingot, the assembly, welding, evacuation, and sealing of the cladding billets, the jacketing of the cladding billets with steel, and the roll bonding, heat treatment, stripping, and cleaning of the fuel plates. Evaluation of the fuel plates produced is also included.

Y-4

REACTIVITY IN SODIUM REACTOR EXPERIMENT OF THE BETTIS ALLOYS. J. J. McClure (Atomics International, Conoga Park, California.) Report NAA-SR-Memo-2805. May 21, 1958. 4p.

The reactivities of several U-Nb-Zr alloys in the Sodium Reactor Experiment are compared with that of $2.8 \%$ enriched $U$ fuel. The alloys considered have the following compositions: $15 \% \mathrm{Nb}-70 \% \mathrm{U}-15 \% \mathrm{Zr} ; 12 \% \mathrm{Nb}-82 \% \mathrm{U}-6 \% \mathrm{Zr}$; and $6 \% \mathrm{Nb}-82 \% \mathrm{U}-12 \% \mathrm{Zr}$. Each alloy is studied at $U$ enrichments of 3,7 , and $11 \%$, and the alloy enrichments necessary to give the same reactivity as the $2.8 \%$ enriched $U$ fuel are found by interpolation.

Y-5

TERNARY ALLOYS OF URANIUM, COLUMBIUM, AND ZIRCONIUM. F. G. Foote. British Patent 803,118. Nuclear Eng. 4:284. June 1959.

Uranium metal cast in the high temperature gamma phase $\left(1000^{\circ} \mathrm{C}\right)$ has greater resistance to corrosion by oxidation than in any other phase. This is important when using ternary alloys of uranium as neutron-reflecting materials in a fast neutron pile. Uranium metalbecomes stabilized in the gamma phase when closely alloyed with minor amounts of columbium and zirconium in combination ( 2 to $8 \%$ ).

Y.6

TERNARY ALLOYS OF URANIUM, COLUMBIUM, AND ZIRCONIUM. F. G. Foote (to U.S. Atomic Energy Commission). U.S. Patent 2,947,621. Aug 2, 1960.

Ternary alloys of uranium are described which are useful as neutron-reflecting materials in a fast neutron reactor. They are especially resistant to corrosion caused by oxidative processes of gaseous or aqueous origin and comprise uranium as the predominant metal with zirconium and niobium wherein the total content of the minor alloying elements is between 2 and $8 \%$ by weight. 
RFP-21 58

PART II. 
PART II.

Progress Reports and Newsletters

In Part II, the references are categorized according to source and not subject. Within a given source, the references are listed chronologically. The items have been included in the subject index.

\section{$\underline{\mathbf{Z A}}$}

AMES LABORATORY, AMES, IOWA

ZA-1

QUARTERLY SUMMARY RESEARCH REPORT FOR OCTOBER-DECEMBER 1952. P. Chiotti and O. N. Carlson. ISC-314. Jan 1953.

Declassified Feb 26, 1957. 26p.

Constitution diagrams, corrosion, and mechanical properties of $\mathrm{Nb}-\mathrm{U}-\mathrm{Zr}$.

\section{ZA-2}

QUARTERLY SUMMARY RESEARCH REPORT IN METALLURGY FOR APRIL, MAY, AND JUNE 1953. ISC-396. Nov 16, 1953. Declassified Feb 26, 1957. 35p.

Corrosion resistance and hardness of $\mathrm{U}-\mathrm{Zr}-\mathrm{Nb}$ alloys.

ZA-3

SLUG PROGRAM QUARTERLY REPORT FOR APRIL, MAY, JUNE 1953. P. Chiotti and O. N. Carlson. ISC-389. Aug 12, 1953.

Declassified Feb 26, 1957. 32p.

Studies of corrosion and grain size in $\mathrm{U}-\mathrm{Zr}-\mathrm{Nb}$ alloys.

ZA-4

QUARTERLY SUMMARY RESEARCH

REPORT IN METALLURGY FOR JULY, AUGUST, SEPTEMBER 1953. ISC-423.

Feb 18, 1954. Declassified Feb 26, 1957.

46p.

Corrosion of alpha-annealed and alpha quenched $\mathrm{U}-\mathrm{Zr}-\mathrm{Nb}$ alloy in boiling and $178^{\circ} \mathrm{C}$ water.

ZA-5

QUARTERLY SUMMARY RESEARCH

REPORT FOR APRIL, MAY, AND JUNE 1954.

P. Chiotti and O. N. Carlson, Compilers.
ISC-507. Sep 7, 1954. Declassified Feb 26, 1957. $31 \mathrm{p}$.

Corrosion resistance of $\mathrm{U}-\mathrm{Zr}-\mathrm{Nb}$ alloys.

ZA:6

QUARTERLY SUMMARY RESEARCH

REPORT IN METALLURGY FOR OCTOBER, NOVEMBER, DECEMBER 1953. ISC-453.

May 25, 1954. Declassified Mar 28, 1957.

48p.

Corrosion of $\mathrm{U}-\mathrm{Zr}-\mathrm{Nb}$ alloys in water.

$\underline{\text { ZB }}$

ARGONNÉ NATIONAL LABORATORY, ARGONNE (LEMONT), ILLINOIS

ZB-1

METALLURGY DIVISION QUARTERLY

REPORT FOR OCTOBER, NOVEMBER, AND

DECEMBER 1953. ANL-5234. Dec 31, 1953.

Declassified Feb 12, 1957. 78p.

Microstructure and hardness of $\mathrm{U}-\mathrm{Zr}-\mathrm{Nb}$ alloys.

ZB-2

REACTOR ENGINEERING DIVISION QUARTERLY REPORT FOR SEPTEMBER 1, 1953 THROUGH NOVEMBER 30, 1953. ANL5208. Dec 15, 1953. Declassified Apr 16, 1957. 170 p.

Corrosion data on U-Nb-Zr alloys by water.

ZB-3

METALLURGY DIVISION QUARTERLY REPORT FOR JANUARY, FEBRUARY, AND MARCH 1954. ANL-5257. Mar 31, 1954. Declassified Feb 12, 1957. 63p.

Casting of U-Nb-Zr alloys. Cast bonding of $\mathrm{U}-\mathrm{Nb}-\mathrm{Zr}$ alloy to zircaloy. Corrosion of $\mathrm{U}-\mathrm{Nb}-\mathrm{Zr}$ alloy by water at $300^{\circ} \mathrm{C}$.

ZB-4

REACTOR ENGINEERING DIVISION QUARTERLY REPORT FOR APRIL 1, 1954 THROUGH JUNE 30, 1954. ANL-5297. July 15, 1954. Declassified Mar 28, 1957. 206p. Water corrosion of unclad U-Nb-Zr alloys at high temperature. 
ZB-5

QUARTERLY PROGRESS REPORT ON

REACTOR DEVELOPMENT. ANL-5313.

July 31,1954 . Declassified Mar 29, 1957. 42p.

Corrosion of U-Nb-Zr alloys.

\section{ZB-6}

REACTOR ENGINEERING DIVISION QUARTERLY REPORT FOR OCTOBER 1, 1954 THROUGH DECEMBER 31, 1954.

ANL-5371. Jan 15, 1955. Declassified Jan 17, 1957. 284p.

Unclad U-Nb-Zr alloy samples were corrosion tested in 500 and $550^{\circ} \mathrm{F}$ water.

\section{ZB-7}

REACTOR DEVELOPMENT QUARTERLY PROGRESS REPORT. ANL-5398. Jan 31, 1955. Declassified Jan 21, 1957. 63p.

The most corrosion-resistant $\mathrm{U}-\mathrm{Zr}-\mathrm{Nb}$ alloy developed so far is produced by heating in a vacuum to the gamma phase, quenching, and aging two hours at $400^{\circ} \mathrm{C}$. Special attention is given to the removal of $\mathrm{H}_{2}$ from the material. Unclad and unirradiated samples of $\mathrm{U}-\mathrm{Nb}-\mathrm{Zr}$ alloys were corrosion tested in $\mathrm{H}_{2} \mathrm{O}$. Corrosion rates were also measured under irradiation conditions.

\section{ZB-8}

FABRICATION OF PROTOTYPE FUEL ELEMENTS FOR THE EXPERIMENTAL BOILING WATER REACTOR AND THE EXPERIMENTAL BREEDER REACTOR. YEARLY REPORT: JULY 1, 1954 TO JUNE 30, 1955. H. F. Sawyer, P. Loewenstein, W. C. Paynton, and P. Corzine. May 1956. Declassified Mar 14, 1957. $41 \mathrm{p}$.

Thermal expansion and transformation characteristics for the U-5 wt \% Zr-1.5 wt \% Nb alloy are given.

\section{ZB-9}

METALLURGY DIVISION QUARTERLY REPORT FOR JANUARY, FEBRUARY, AND MARCH 1955. ANL-5439. Sep 1955.

Declassified Feb 12, 1957. 59p.

Melting, casting, and phase studies of $\mathrm{Nb}-\mathrm{U}-\mathrm{Zr}$ alloys.
ZB-10

METALLURGY DIVISION QUARTERLY

REPORT FOR APRIL, MAY, AND JUNE 1955. ANL-5465. Nov 1955. Declassified Feb 12, 1957. 72p.

Casting and melting of $\mathrm{Nb}-\mathrm{U}-\mathrm{Zr}$ alloys.

ZB-11

METALLURGY DIVISION QUARTERLY

REPORT FOR JULY, AUGUST, AND

SEPTEMBER 1955. ANL-5489. Mar 1956.

Declassified Feb 12, 1957. 67p.

Phase studies and microstructures of $\mathrm{U}-\mathrm{Nb}-\mathrm{Zr}$ alloys.

\section{ZB-12}

METALLURGY DIVISION QUARTERLY REPORT FOR OCTOBER, NOVEMBER, AND DECEMBER 1955. ANL-5541. June 1956. Declassified Feb 12, 1957. 55p.

Phase diagram for $\mathrm{Nb}-\mathrm{U}-\mathrm{Zr}$ alloys.

ZB-13

METALLURGY DIVISION QUARTERLY REPORT FOR JANUAAR, FEBRUARY, AND MARCH 1956. ANL-5563. June 1956.

Declassified Feb 12, 1957. 56p.

Phase diagram and production of $\mathrm{Nb}-\mathrm{U}-\mathrm{Zr}$ alloys.

ZB-14

METALLURGY DIVISION ANNUAL REPORT FOR 1962. ANL-6677. 1963. 410p.

Mechanical properties of U-Nb-Zr alloys.

ZB-15

REACTOR SAFETY. In ANL-6900, p232:303. 1964.

Fission product release of clad U-Nb-Zr alloys during meltdown in TREAT. In these studies, small fuel specimens were submerged in water in high pressure autoclaves which were then placed in the center of TREAT and subjected to severe nuclear transients.

ZB-16

REACTOR DEVELOPMENT PRÓGRAM PROGRESS REPORT, MARCH 1965. ANL-7028. Apr 20, 1965. 93p.

Radiation effects on U-Nb-Zr alloys during:a reactor excursion. 


\section{ZB-17}

REACTOR SAFETY. In ANL-7055, p177-212. 1965. L. Baker, Jr. and A. D. Tevebaugh.

Reactions of U-Nb-Zr alloys with water during Kiwi-TNT transients.

ZB-18

REACTOR SAFETY. In ANL-7125, p 150-199. 1966. L. Baker, Jr., A. D. Tevebaugh, and J. D. Bingle.

Reaction of U-Nb-Zr alloys with water during Kiwi-TNT transients.

\section{$\underline{\mathrm{ZC}}$}

\section{BATTELLE MEMORIAL INSTITUTE, COLUMBUS, OHIO}

ZC-1

PROGRESS RELATING TO CIVILIAN APPLICATIONS DURING JUNE 1956. Russell W. Dayton and Clyde R. Tipton, Jr. BMI-1104. July 2, 1956. Declassified Feb 18, 1960. 88p.

Mechanical properties of U-Nb-Zr alloy

ZC-2

REACTOR CORE MATERIALS. Technical Progress Reviews 1. Battelle Memorial Institute, Columbus, Ohio. 1958. 47p.

Water corrosion data for $\mathrm{Nb}-\mathrm{U}-\mathrm{Zr}$ alloys.

ZC-3

PROGRESS RELATING TO CIVILIAN APPLICATIONS DURING AUGUST 1961. Russell W. Dayton and Clyde R. Tipton, Jr. BMI-1541. Sep 1, 1961. 84p.

Corrosion of U-Nb-Zr alloys by sodium at 1600 and $1800^{\circ} \mathrm{C}$.

\section{$\underline{\text { ZD }}$}

BUREAU OF MINES, ALBANY, OREGON

ZD-1

QUARTERLY PROGRESS REPORT

NUMBER 14 ON METALLURGY APRIL 1,
1964-JUNE 30, 1964. UCRL-13341.

June 1964. 26p.

Composition and preparation of $\mathrm{U}-\mathrm{Nb}-\mathrm{Zr}$ alloys.

$$
\begin{gathered}
\underline{\text { ZE }} \\
\text { UNIVERSITY OF CHICAGO, } \\
\text { CHICAGO, ILLINOIS }
\end{gathered}
$$

ZE-1

PHYSICS AND METALLURGY DIVISION REPORT FOR MONTH OF FEBRUARY 1946. CP-3445. Feb 27, 1946. Declassified Mar 13, 1957. 10p.

Weight change rates of 19 uranium base alloys (including $\mathrm{U}-\mathrm{Nb}-\mathrm{Zr}$ ) were measured.

\section{$\underline{\mathrm{ZF}}$ \\ DIVISION OF RESEARCH, U.S. ATOMIC ENERGY COMMISSION, WASHINGTON, D.C.}

ZF-1

.. URANIUM ALLOY NEWSLETTER NO. 5. David W. Lillie, Ed. WASH-126. Nov 1953. Declassified Feb 16, 1960. 35p.

Various corrosion tests on water quenched U-Nb-Zr alloys in distilled water are reported. (Work done at Argonne National Laboratory, Lemont, Illinois.)

\section{ZF-2}

URANIUM ALLOYS NEWSLETTER NO. 6. David W. Lillie, Ed. WASH-153. Feb 5, 1954. Declassified Nov 30, 1959. 61p.

Phase studies under way at Argonne National Laboratory are reported. Corrosion studies at Westinghouse Atomic Power Laboratory as a function of water testing temperature are also presented.

ZF-3

URANIUM ALLOY NEWSLETTER NO. 7. David W. Lillie, Ed. WASH-154. May 1954. Declassified Dec 1, 1959. 61p. 
Work at Argonne National Laboratory, Lemont, Illinois, includes the method of fabrication of $\mathrm{Nb}-\mathrm{U}-\mathrm{Zr}$ alloys and the effect of silicon on corrosion resistance. Work at the Ames Laboratory, Ames, Iowa, deals with the effect of aging temperature upon hardness and electrode potentials of quenched U-Nb-Zr alloys.

\section{ZF-4}

URANIUM ALLOY NEWSLETTER NO. 8. David W. Lillie, Ed. WASH-155. Aug 1954. Declassified Oct 7, 1959. 66p.

Investigations were designed to evaluate the corrosion resistance of quenched $\mathrm{Nb}-\mathrm{U}-\mathrm{Zr}$ alloys in $300^{\circ} \mathrm{C}$ distilled water.

\section{ZF-5}

URANIUM ALLOY NEWSLETTER NO. 9. J. Fred White, Ed. WASH-156. Nov 1954. Declassified Mar 5, 1957. 42p.

A series of $\mathrm{Nb}-\mathrm{U}-\mathrm{Zr}$ alloys were annealed at $450{ }^{\circ} \mathrm{C}$ for 150 hours and $425^{\circ} \mathrm{C}$ for 165 hours in an effort to determine the maximum temperature at which the alloys can be annealed and still retain their corrosion resistance. (Ames Laboratory, Ames, Iowa.)

\section{ZF-6}

URANIUM ALLOY NEWSLETTER NO. 12. Edward Epremian, Ed. WASH-199. Oct 1955. Declassified Mar 30, 1960. 50p.

The lower bonding surface of the single-phase gamma region was determined for $\mathrm{U}$ alloys containing up to $8 \mathrm{wt} \% \mathrm{Zr}$ and $5 \mathrm{wt} \% \mathrm{Nb}$. (Argonne National Laboratory, Lemont, Illinois.)

\section{ZF-7}

URANIUM ALLOY NEWSLETTER NO. 13. Edward Epremian, Ed. WASH-295. Nov 1955. Declassified Mar 5, 1958. 50p.

Results are summarized from irradiation and corrosion tests of $\mathrm{U}-\mathrm{Nb}-\mathrm{Zr}$ alloys (Argonne National Laboratory). Nuclear Metals, Inc. report studies on the thermal properties of $\mathrm{U}-\mathrm{Nb}-\mathrm{Zr}$ alloys.
ZF-8

URANIUM ALLOY NEWSEETTER NO. 14. Edward Epremian, Ed. WASH-296. Mar 1956. Declassified Mar 6, 1957. 62p.

Corrosion and irradiation studies on $\mathrm{U}-\mathrm{Nb}-\mathrm{Zr}$ alloys are reported (Argonne National Laboratory).

ZF-9

NUCLEAR FUELS NEWSLETTER. Edward Epremian, Ed. WASH-703. Aug 1957.

Declassified Mar 30, 1960. 40p.

Transformation kinetics of $\mathrm{U}-\mathrm{Nb}-\mathrm{Zr}$ alloys. Physical properties of gamma phase $\mathrm{U}-\mathrm{Nb}-\mathrm{Zr}$ alloys.

\section{$\underline{\mathbf{Z G}}$}

FUEL AND FERTILE MATERIALS, U.S. ATOMIC ENERGY COMMISSION, WASHINGTON, D.C.

ZG-1

FUEL AND FERTILE MATERIALS. Reactor Mater. 8:1-17. Spring 1965.

Properties of metastable gamma-phase $\mathrm{U}-\mathrm{Nb}-\mathrm{Zr}$ alloys are reported.

ZG-2

FUEL AND FERTILE MATERIALS. Reactor Mater. 9:151-165. Fall 1966.

Reaction of unclad U-Nb-Zr fuel elements with water.

\section{ZG-3}

FUEL AND FERTILE MATERIALS. Reactor Mater. 9:203-216. Winter 1966-1967.

Physical and mechanical properties of $\mathrm{U}-\mathrm{Nb}-\mathrm{Zr}$ alloys.

ZG-4

FUEL AND FERTILE MATERIALS. Reactor Mater. 11:205-219. Winter 1968-1969.

Delayed cracking of gamma-phase U-Nb-Zr alloys in wet and dry air. 
$\underline{\mathrm{ZH}}$

NATIONAL LEAD COMPANY OF OHIO, CINCINNATI, OHIO

ZH-1

SUMMARY TECHNICAL REPORT FOR THE PERIOD JANUARY 1, 1955 TO MARCH 31, 1955. J. W. Simmons, Ed. TID-10112. Apr 15, 1955. Declassified Apr 28, 1960. 170p.

Preparation of U-Nb-Zr alloy by reduction of fluorides.

\section{ZH-2}

SUMMARY TECHNICAL REPORT FOR THE PERIOD APRIL 1, 1955 TO JUNE 30, 1955.

J. W. Simmons, Ed. NLCO-565. July 15, 1955. Declassified Mar 31, 1960. 170p.

Analysis of $\mathrm{U}-\mathrm{Nb}-\mathrm{Zr}$ alloys for uranium.

\section{$\underline{\mathrm{ZI}}$}

OAK RIDGE NATIONAL LABORATORY, OAK RIDGE, TENNESSEE

\section{ZI-1}

METALLURGY DIVISION ANNUAL PROGRESS REPORT FOR PERIOD ENDING MAY 31, 1961. ORNL-3160. Aug 17, 1961. 207p.

Creep properties of gamma quenched $\mathrm{U}-\mathrm{Nb}-\mathrm{Zr}$ alloys.

\section{ZI-2}

SURFACE REACTIONS METALS. J. V. Cathcart. ORNL-4470, 45-49. (From Annual Progress Report for period ending June 30, 1969.)

The effect of stress was evident in the surface morphology of the oxide formed on U-7.5\% $\mathrm{Nb}-2.5 \% \mathrm{Zr}$. Oxidation rate measurements between 160 and $276{ }^{\circ} \mathrm{C}$ are reported as well as the results of a hot-stage-microscope study of the oxidation of the alloy at $800^{\circ} \mathrm{C}$.
ZI-3

X-RAY DIFFRACTION. H. L. Yakel. ORNL-4470, 52-57. (From Annual Progress Report for period ending June 30, 1969.)

Crystal structure of phases in U-Nb-Zr alloys.

ZI-4

DISLOCATIONS AND RADIATION EFFECTS ON PLASTIC DEFORMATION. ORNL-4526, 17-24. (From Annual Progress Report for period ending June 30, 1969.)

Effects of heat treatment on the internal friction spectrum of U-Nb-Zr alloys.

\section{ZI-5}

SURFACE REACTIONS OF METALS.

ORNL-4570, 37-39. (From Metals and Ceramics Division Annual Progress Report for the period ending June 30, 1970.)

A model was developed for the oxidation of the ternary alloy $\mathrm{U}-7.5 \mathrm{wt} \% \mathrm{Nb}-2.5 \mathrm{wt} \% \mathrm{Zr}$ and the binary U-9.4 wt \% Nb. Transient stresses on the order of the $10^{6}$ psi exist at the oxide-metal interface of these alloys, and these stresses can trigger phase transformations in the alloy and control oxide morphology.

ZI-6

X-RAY DIFFRACTION. ORNL-4570, 44-46. (From Metals and Ceramics Division Annual Progress Report for the period ending June 30, 1970.)

Aging reactions of gamma-stabilized uranium alloys (U-Nb-Zr) have been followed by $\mathrm{X}$-ray diffraction experiments at a series of aging conditions. Effects of sample deformation on the reactions are also being examined.

ZI-7

FUNDAMENTAL PHYSICAL METALLURGY. ORNL-4770, 20-21. Sep 1971. (From Metals and Ceramics Division Annual Progress Report for period ending June 30, 1971.) 
Rolling and recrystallization textures of a metastable bcc uranium alloy (U-Nb-Zr) were determined. Partial correlation functions were derived for vacancy diffusion in body-centered tetragonal lattices. Auger electron spectra for each element have been calculated and cataloged.

\section{ZI-8}

SURFACE PHENOMENA. ORNL-4770, 28-30. Sep 1971. (From Metals and Ceramics Division Annual Progress Report for period ending June 30, 1971.)

The oxidation properties of a series of uraniumbase alloys containing $\mathrm{Nb}, \mathrm{Zr}, \mathrm{Ti}$, and Mo were studied. Special emphasis was placed on characterizing the complex morphology of the oxide films and on determining the origin of the oxide film stresses.

\section{ZI-9}

X-RAY DIFFRACTION. ORNL-4770, 34-37. Sep 1971. (From Metals and Ceramics Division Annual Progress Report for period'ending June 30, 1971.)

Additional X-ray diffraction observations of aging reactions in gamma-quenched uranium-base alloys (U-Nb-Zr alloys) provided clues to the memory effects shown by the material.

ZI-10

METALLOGRAPHY. . ORNL-4770, 186-194. Sep 1971. (From Metals and Ceramics Division Annual Progress Report for period ending June 30, 1971.)

Analysis of the crystal structure of the oxide layer on $\mathrm{U}-\mathrm{Nb}-\mathrm{Zr}$ alloys using the electron microprobe is described.

\section{ZI-11}

FUNDAMENTAL PROGRAMS. ORNL-4820, 1-37. Sep 1972. (From Metals and Ceramics Division Annual Progress Report for period ending June 30, 1972.)

Mechanisms of phase transformations in $\mathrm{U}-\mathrm{Nb}-\mathrm{Zr}$ alloys.
WESTINGHOUSE ELECTRIC CORPORATION, PITTSBURGH, PENNSYLVANIA

ZJ-1

PRESSURIZED WATER REACTOR PROGRAM TECHNICAL PROGRESS REPORT FOR THE PERIOD NOVEMBER 18, 1954 TO DECEMBER 30, 1954. WAPD-MRP-50. Declassified Feb 7, 1957. 92p.

Water corrosion of U-Zr-Nb alloys.

\section{ZJ-2}

PRESSURIZED WATER REACTOR PROGRAM TECHNICAL PROGRESS REPORT FOR. THE PERIOD DECEMBER 30, 1954 TO FEBRUARY 10, 1955. TID-10138. Declassified Mar 18, 1957. $111 \mathrm{p}$.

Corrosion studies previously reported on U-Mo, U-Mo-Pt, U-Mo-Nb, U-Zr-Nb, and Zr-clad U alloys are continued. The addition of $\mathrm{Ni}$ and $\mathrm{Pt}$ ions to the corrosion test water was found to appreciably inhibit $\mathrm{H}$ pickup by gamma phase alloys.

\section{ZJ-3}

RESUME OF URANIUM ALLOY DATA VIII. B. Lustman. WAPD-PMM-15. Feb 25, 1955. Declassified Mar 20, 1957. 83p.

Corrosinn of IJ-Nh-7r alloys by $300^{\circ} \mathrm{C}$ water.

ZJ-4

PRESSURIZED WATER REACTOR PROGRAM TECHNICAL PROGRESS REPORT FOR THE PERIOD DECEMBER 2,1955 TO JANUARY 12, 1956. WAPD-MRP-59. Declassified Feb 7, 1957. 98p.

Thermal stability of $\mathrm{U}-\mathrm{Nb}-\mathrm{Zr}$ alloys.

\section{ZJ-5}

PRESSURIZED WATER REACTOR PROGRAM TECHNICAL PROGRESS REPORT FOR THE PERIOD JANUARY 13, 1956 TO FEBRUARY 23, 1956. WAPD-MRP-60. Jan 2, 1958. 95p.

The thermal stability of U-Nb-Zr alloys was studied. 


\section{ORGANIZATIONAL REPORT SYMBOLS}

\begin{abstract}
A/CONF $15 / P($ no.)

ANL

United Nations, International Conference on the Peaceful Uses of Atomic Energy, Geneva, Switzerland. 1958.

Argonne National Laboratory, Argonne (Lemont), Illinois.
\end{abstract}

ARF

BMI

BNL

BNWL

CEA-R

Columbus, Ohio.
Cholle Memorial Inst Upton, New York. Northwest Laboratory.
CONF

CP

CT

Brookhaven National Laboratory,

GA

Battelle Northwest Laboratory, Richland, Washington. Pacific

Commissariat a l'Energie A tomique, Saclay or Valduc, France.

Centre d'Etudes Nucleaires.
GEPM
Center for Nuclear Studies, Saclay, France.
EUR

$\mathrm{CF}-$

(yr-mo)

Oak Ridge National Laburatory, Oak Ridge, Tennessee.

Serial number assigned to conference cataloged by the Division of Technical Information Extension, U.S. Atomic Energy Commission, Oak Ridge, Tennessee.

University of Chicago, Metallurgical Laboratory, Chicago, Illinois:

University of Chicago, Metallurgical Laboratory, Chicago, Illinois.

European Atomic Energy Community, Nuclear Research Center, Ispra, Italy.
General Electric Company, Research Laboratory, Schenectady, New. York.

Homogeneous Reactor Test, Oak

Ridge National Laboratory, Oak Ridge, Tennessee. 
RFP-2158

IMD

ISC

LA

or LASL

MLM

NAA-SR

NLCO

NMI

NP

NRU

ORNL
North American Aviation, Incorporated, Downey, California.

Institute of Metals Division of

Metallurgical Society of Americàn Institute of Mining, Metallurgical, and Petroleum Engineers, New York.

SC

SCL

Los Alamos Scientific Laboratory, Los Alamos, New Mexico.

TID

Mound Laboratory, Miamisburg, Ohio.

UCID

UCRL

$$
\text { Cincinnati, Ohio. }
$$

USAEC

USSR

Division of Technical Information

Extension, U.S. Atomic Energy

Commission, Oak Ridge,

Tennessee.

WAPD

WASH

Canada, Ltd., Chalk River,

Ontario, Canada.

Oak Ridge National Laboratory, Oak Ridge, Tennessee:

\section{Experimental and Production}

Reactor, A tomic Energy of

Y
Rocky Flats (Plant) Division, Dow

Chemical U.S.A., Golden,

Colorado.

Sandia Corporation, Albuquerque, New Mexico.

Sandia Laboratories, Livermore, California.

Division Technical Information Extension, U.S. Atomic Energy

Division, Oak Ridge, Tennessee.

University of California at Berkeley, Radiation Laboratory, Berkeley, California:

Lawrence Radiation Laboratory; University of California, Livermore, California.

U.S. Atomic Energy Commission, Washington, D.C.

Union of Soviet Social Republic, Moscow, Russia.

Westinghouse Electric Corporation Atomic Power Division, Pittsburgh, Pennsylvania.

Union Carbide Corporation, Y-12 Plant, Oak Ridge,' Tennessee. 


\section{SUBJECT INDEX AND ABSTRACT NUMBERS}

$\underline{A}$

$\begin{array}{ll}\text { Activation Energy } & \text { J-1 } 1, \text { S-3 } \\ \text { Aging } & \text { F-1, F-5, J-3, T-4, V-1, } \\ & \text { V-2, V-4, V-5, X-8, } \\ & \text { ZF-3, ZF-5, ZI-6, ZI-9 }\end{array}$

Auger Electron Spectra $\mathrm{ZI}-7$

Alloying.

Alloy Theory

Burnup

Cast Bonding

Casting

Casting,

Agitation during

Cathodic

Vacuum Etching

Centrifugal Casting

Chemical Analysis

Cladding

Coextrusion

Constitutional

Diagrams

Corrosion
C-4

F-5, L-1, P-4, P-5, S-2, T-2, T-3

B

$\mathrm{X}-9$

$\underline{\mathrm{C}}$

ZB-3

C-1, C-4, ZB-3, ZB-9, ZB-10

C-2

N-4

C-1, C-2, E-1

I-1 , I-2, ZH-2

E-1, E-2, E-3, E-4; X-3, X-8, Y-2, Y-3, ZB-1 5

E-2

$\mathrm{T}-1, \mathrm{~T}-2, \mathrm{~T}-3, \mathrm{~T}-4, \mathrm{~T}-5$, T-6, T-7, V-1, V-2, Y-1, ZA-1

F-13, J-2, J-3, J-6, J-9, J-10, J-1 1, L-1; L-3, M-2, O-1, Q-2, R-2, X-1, Y-1, Y-5, Y-6, ZA-1-ZA-6, ZB-2-ZB-6, ZC-2, ZF-1-ZF-5, ZF-7, ZF-8, ZJ-1-ZJ-3
Corrosion, Crevice $\quad 0-1$

Corrosion, Effects J-5, ZB-7 of Radiation

Corrosion, Inhibitor $\quad$ ZF-3, ZJ-2

Corrosion Product $\quad \mathrm{M}-10$ Wedging

Corrosion Resistance D-1, E-5, G-1, G-2, J-1, $\mathrm{J}-4, \mathrm{~J}-7, \mathrm{~J}-8, \mathrm{O}-2, \mathrm{X}-2, \mathrm{X}-3$

Corrosion by Sodium ZC-3

Crack Initiation

M-7, M-9 and Growth

Cracking

M-1, M-2

Creep Properties

F-2, ZI-1

Crystallography

P-1, P-5, V-2, V-4, W-1

Crystal Structures

ZI-3, ZI-6

D

Deformation . P-3, P-4

Delayed Cracking $\quad \mathrm{M}-4, \mathrm{ZG}-4$

Diffusion . L-5, S-2, S-3, ZI-7

Diffusion Bonding E-4

Diffusion with $\quad$ S-1 Molybdenum

Dilatometry $\quad$ V-7

Dimensional Stability G-1, G-2, G-3, L-4, X-1, $\mathrm{X}-8$

Discontinuous Failure $\quad$ L-1

Dissolution

$\mathrm{H}-1, \mathrm{H}-2$ 
RFP-21.58

\begin{tabular}{|c|c|c|c|}
\hline Electrical Resistance & $\dot{\mathrm{P}}-4$ & Homogenization & C-4, D-1, V-1 \\
\hline Electrical Resistivity & $M-4, V-6$ & Hot Hardness & D-1 \\
\hline $\begin{array}{l}\text { Electrochemical } \\
\text { Corrosion }\end{array}$ & Q-2 & Hydrogen Effects & O-1, O-2, ZJ-2 \\
\hline Electrochemistry & $\mathrm{M}-11, \mathrm{Q}-2$ & & \\
\hline Electrode Potentials & $Z F-3$ & & $\underline{I}$ \\
\hline Electron Metallography & $\mathrm{F}-10, \mathrm{~N}-1, \mathrm{~N}-2$ & Impact Strengths & F-1 2 \\
\hline Electron Microprobe & $\mathrm{ZI}-10$ & Impurity Effects & $\mathrm{ZF}-3$ \\
\hline Entropy & $\mathrm{R}-1$ & Inclusions & $\mathrm{M}-4, \mathrm{O}-3, \mathrm{O}-4$ \\
\hline Environmental Effects & V-8 & Industrial Hygiene & E-7 \\
\hline Equation of State & R-1 & Internal Friction & $Z I-4$ \\
\hline $\begin{array}{l}\text { Etching } \\
\text { Explosion Hazard }\end{array}$ & $\begin{array}{l}\mathrm{K}-1 \\
\mathrm{~K}-1, \mathrm{~K}-2, \mathrm{~K}-3\end{array}$ & Irradiation Effects & $\begin{array}{l}\text { E-5, J-4, Q-1, X-1-X-10, } \\
\text { Y-2, Y-4, ZB-7, ZB-15, } \\
\text { ZB-16, ZF-7, ZF-8 }\end{array}$ \\
\hline & $\underline{\mathrm{F}}$ & $\begin{array}{l}\text { Irradiation Heat } \\
\text { Treatment }\end{array}$ & $\mathrm{J}-5$ \\
\hline Fabrication & $\begin{array}{l}\mathrm{C}-4, \mathrm{E}-6, \mathrm{E}-7, \mathrm{G}-1, \mathrm{G}-2 \\
\mathrm{Y}-3, \mathrm{ZB}-12, \mathrm{ZF}-3\end{array}$ & $\begin{array}{l}\text { Irradiation Stability } \\
\text { Isothermal }\end{array}$ & $\begin{array}{l}T-1 \\
F-6, F-12, V-2-V-9\end{array}$ \\
\hline $\begin{array}{l}\text { Fabrication, Fuel } \\
\text { Elements }\end{array}$ & E-1, E-2, E-3; E-4, E-5 & Transformations & \\
\hline Flexure Measurements & $\mathrm{R}-2$ & & \\
\hline Fractography & F-10, N-3, N-5 & & $\underline{\mathrm{L}}$ \\
\hline Fracture & $M-6, M-8$ & Lattice Strain & $\mathrm{T}-1$ \\
\hline Fracture Mechanics & $\mathrm{M}-10$ & Literature and & A-2, A-3 \\
\hline Fuel Elements & $\begin{array}{l}\text { A-1, E-1, E-2, E-3, E-4, } \\
\text { E-5, F-9, X-2, X-5, X-6, } \\
\text { X-8, X-9, Y-1, Y-2, Y-5, } \\
\text { Y-6, Y-3, Y-4, ZG-2 }\end{array}$ & Property Reviews & $\underline{\mathrm{M}}$ \\
\hline & & Martensite & $\mathrm{T}-6, \mathrm{~W}-1$ \\
\hline Galvanic Series & $\begin{array}{l}\underline{\mathrm{G}} \\
\mathrm{J}-9 \\
\mathrm{C}-2\end{array}$ & Mechanical Properties & $\begin{array}{l}\text { A-1-A-3, C-4, F-1-F-8, } \\
\text { F-12, F-13, M-4, P-4, } \\
\text { ZA-1, ZB-14, ZC-1, ZG-3 }\end{array}$ \\
\hline $\begin{array}{l}\text { Grain Refinement } \\
\text { Grain Size }\end{array}$ & $\begin{array}{l}\mathrm{C}-2 \\
\mathrm{ZA}-3\end{array}$ & $\begin{array}{l}\text { Mechanical Properties, } \\
\text { Elevated Temperature }\end{array}$ & F-6 \\
\hline & & Meltdown & ZB-15 \\
\hline & & Memory Effect & ZI-9 \\
\hline Hardness & $\underline{\mathrm{H}}-1, \mathrm{~J}-1, \mathrm{~V}-2, \mathrm{~V}-6, \mathrm{Y}-1$ & Melting & $\begin{array}{l}\text { C-1, C-2, C-4, ZB-9, } \\
\text { ZB-10 }\end{array}$ \\
\hline Heat Treatments & $\begin{array}{l}\text { ZA-1, ZB-1 } \\
\mathrm{J}-1, \mathrm{Y}-1\end{array}$ & $\begin{array}{c}\text { Metallographic } \\
\text { Techniques }\end{array}$ & $\begin{array}{l}\text { F-10, I-2, N-1-N-5, } \\
\text { O-4 }\end{array}$ \\
\hline
\end{tabular}


Metastable Phase

Microprobe Analysis

Microstructure

Moduli of Elasticity

(High T)

Mulberry Alloy

(See uranium-7.5

niobium-2.5

zirconium)

Neutron Reflection $\quad$ Y-6

Q

\begin{tabular}{|c|c|c|c|}
\hline & $\underline{\mathbf{O}}$ & & $\underline{\mathbf{S}}$ \\
\hline Ordering & F-5, W-1 & Safety & $\mathrm{E}-7, \mathrm{~K}-2, \mathrm{~K}-3$ \\
\hline Oxidation & $\begin{array}{l}\text { J-10, J-11, J-12, L-1, L-2, } \\
\text { L-3, L-4, M-12, R-2, ZE-1, } \\
\text { ZI-2, ZI-5, ZI-8, ZI-10 }\end{array}$ & Safety, Reactor & $\begin{array}{l}\text { ZB-15, ZB-16, ZB-17 } \\
\text { ZB-18 }\end{array}$ \\
\hline Oxide Films & $\mathrm{J}-2$ & Scale Rupture & L-5 \\
\hline Oxide Stresses & $\mathrm{J}-12, \mathrm{~L}-4, \mathrm{~L}-5$ & $\begin{array}{l}\text { Scanning Electron } \\
\text { Microscopy }\end{array}$ & F-10, N-5 \\
\hline & & Separation, Chemical & $\mathrm{H}-2$ \\
\hline & & Shape Change & L-5 \\
\hline & $\underline{\mathbf{P}}$ & Shear Modulus & F-7 \\
\hline Passivation & M-7 & Shear Spinning & E-7 \\
\hline Patent & B-1 - 5, E-5, G-1, G-2, & Silicon Effects & $\mathrm{ZF}-3$ \\
\hline & Y-5, Y-6 & Sodium Reactor & $Y-4$ \\
\hline Phase Diagram & ZB-9, ZB-12, ZB-13 & eriment & \\
\hline Phase Studies & A-1, T-3, ZB-11, ZF-2, & Solidification & $\mathrm{C}-4$ \\
\hline & $\mathrm{ZF}-6$ & Specific Heat & $\mathrm{R}-1$ \\
\hline Phase Transformation, & P-4 & Spring Back & $P-4$ \\
\hline Stress Induced & & Strain Enhancement of & $V-1$ \\
\hline Physical Properties & A-1, A-2, A-3; F-5, & cipitation & \\
\hline & & Strain Induced Phase & P-5 \\
\hline Pickling & $\mathrm{K}-\mathrm{l}$ & Transtormation & \\
\hline Plastic Deformation & $\mathrm{P}-2$ & Strain Rate & $\mathrm{F}-6, \mathrm{M}-4, \mathrm{P}-3, \mathrm{P}-5$ \\
\hline Preparation & $\mathrm{ZD}-1, \mathrm{ZH}-1$ & Strength Properties & $F-11, P-2$ \\
\hline
\end{tabular}

Production

ZB-13

I-2, N-3

Properties

E-3, ZG-1

Pulsed Fast Reactor

F-9
$\underline{\mathrm{N}}$

\section{ZB-1, ZB-1 1}

F-7

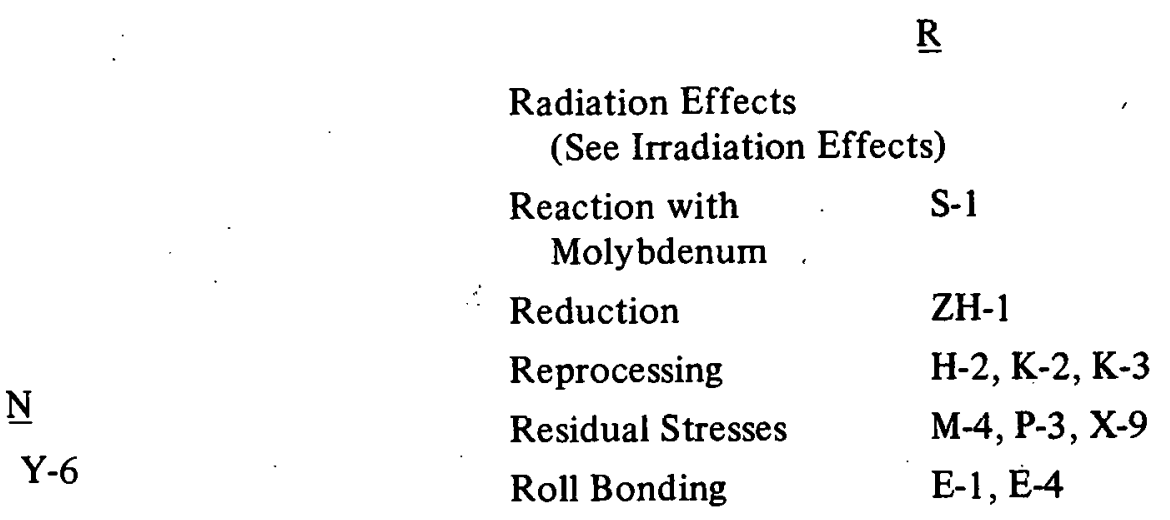


RFP-21 158

\begin{tabular}{|c|c|c|c|}
\hline Stress Corrosion & $\begin{array}{l}\text { L-1, M-1-M-12, N-1, } \\
\text { ZG-4 }\end{array}$ & $\begin{array}{l}\text { Uranium-niobium- } \\
\text { zirconium- }\end{array}$ & $0-3$ \\
\hline Stresses, Oxide & R-2 & & \\
\hline Stress Relief & $F-11, J-12$ & Uranium-25 weight & S-1 \\
\hline Structural Stability & $X-10$ & $\begin{array}{l}\text { percent niobium-5 } \\
\text { weight percent }\end{array}$ & \\
\hline Surface Stability & $X-1$ & zirconium & \\
\hline Surface Studies & $\begin{array}{l}\text { J-4, J-1 1, J-12, L-1-L-5, } \\
\text { M-4, R-2, ZI-2, ZI-5, } \\
\text { ZI-8, ZI-10 }\end{array}$ & $\begin{array}{l}\text { Uranium-5 weight } \\
\text { percent zirconium-1 } \\
\text { weight percent } \\
\text { niobium }\end{array}$ & Y-3, ZB-8 \\
\hline . & $\underline{T}$ & $\begin{array}{l}\text { Uranium-5 weight } \\
\text { percent } \\
\text { zirconium-1.5 weight } \\
\text { percent niobium }\end{array}$ & $\begin{array}{l}\mathrm{C}-3, \mathrm{E}-2, \mathrm{E}-4, \mathrm{~J}-3, \mathrm{~K}-2 \\
\mathrm{O}-2, \mathrm{X}-1, \mathrm{X}-8\end{array}$ \\
\hline Tensile Properties & F-4, F-5, F-6, F-9; F-12 & Uranium-88 weight & $\mathrm{J}-2$ \\
\hline Tensile Properties (Hot) & F-8 & percent zirconium-8 & \\
\hline $\begin{array}{l}\text { Texture, } \\
\quad \text { Recrystallization }\end{array}$ & $\mathrm{ZI}-7$ & $\begin{array}{l}\text { weight percent } \\
\text { niobium }\end{array}$ & \\
\hline Texture, Rolling & ZI-7. & Uranium-zirconium- & $F-2, T-6, V-3$ \\
\hline Thermal Cycling & $\mathrm{G}-3, \mathrm{R}-2$ & $\begin{array}{l}\text { niobium- } \\
\text { molybdenum }\end{array}$ & \\
\hline $\begin{array}{l}\text { Thermodynamic } \\
\text { Properties }\end{array}$ & S-3 & $\begin{array}{l}\text { Uranium-niobium- } \\
\text { zirconium- }\end{array}$ & V-5 \\
\hline Thermal Expansion. & ZB-8. & molybdenum & \\
\hline $\begin{array}{l}\text { Thermal Neutron } \\
\text { Captive Cross Section }\end{array}$ & G-3 & $\begin{array}{l}\text { (+chromium or } \\
\text { vanadium) }\end{array}$ & \\
\hline Thermal Properties & $\mathrm{R}-1, \mathrm{X}-10, \mathrm{ZF}-7$ & & \\
\hline Thermal Stability & $\mathrm{D}-1, \mathrm{ZJ}-4, \mathrm{ZJ}-5$ & & \\
\hline $\begin{array}{l}\text { Transformation } \\
\text { Kinetics }\end{array}$ & $\begin{array}{l}\text { A-1, D-1, } \bar{F}-12, \bar{G}-3, \mathrm{~V}-1 \\
\mathrm{~V}-3, \mathrm{~V}-9, \mathrm{ZF}-9\end{array}$ & Water Reaction & $\begin{array}{l}\underline{W} \\
\text { ZB-17, ZB-18, ZG-2 }\end{array}$ \\
\hline $\begin{array}{c}\text { Transformation } \\
\text { Mechanisms }\end{array}$ & $\mathrm{ZB}-8, \mathrm{ZI}-11$ & Welding & E-6, F-4 \\
\hline $\begin{array}{l}\text { Transformation } \\
\text { Temperatures }\end{array}$ & D-1 & & $\mathbf{X}$ \\
\hline \multirow{3}{*}{$\begin{array}{l}\text { Transition Phase } \\
\text { TTT Diagrams }\end{array}$} & P-5, V-8, W-1 & X-Ray Absorption Edge & $\underline{\mathrm{I}}-1$ \\
\hline & V-6, V-7, V-8, V-9 & X-Ray Studies & $\begin{array}{l}\text { F-12, L-2, M-4, P-3, P-5, } \\
\text { W-1, ZI-9 }\end{array}$ \\
\hline & $\underline{\mathbf{U}}$ & $\begin{array}{l}\text { X-Ray Studies } \\
\text { (High Temperature) }\end{array}$ & P-1 \\
\hline $\begin{array}{l}\text { Uranium- } 7.5 \text { weight } \\
\text { percent niobium- } 2.5 \\
\text { weight percent } \\
\text { zirconium }\end{array}$ & $\begin{array}{l}\text { A-2, A-3, C-4, E-6, F-4, } \\
\text { F-5, F-6, F-10, F-1 1, F-12, } \\
\text { J-9, J-10, J-1 1, L-2, L-3, } \\
\text { L-4, M-3-M-12, N-2, } \\
\text { P-1-P-5, V-8 }\end{array}$ & Yicld Surface & $\begin{array}{l}\underline{Y} \\
P-2\end{array}$ \\
\hline
\end{tabular}




\section{AUTHOR INDEX AND ABSTRACT NUMBERS}

$\underline{A}$

Albright, C. E. Aubert, $\mathrm{H}$.

Badajeva, T. A.

Bagrov, G. N.

Baird, F. G.

Baker, L. Jr.

Barton, T. H.

Bastelli, M. R.

Bauer, A. A.

Bean, C. H.

Bennett, R. K.

Bingle, A. D.

Boland, J. F.

Bugrov, V. A.

Bullock IV, J. S.

Carlander, R.

Carlson, O.N.

Carson, N. J. Jr.

Cathcart, J. V.

Chiotti, P.

Chirigos, J. N.

Chiswik, H. H.

Choquet, $\mathrm{P}$.

Condon, J. B.

Corzine, $\mathrm{P}$.
P-3, P-5

W-1

\section{B}

\section{$\mathrm{T}-2, \mathrm{~T}-7$}

F-2

$\mathrm{K}-2$

ZB-17, ZB-1 8

I-1

$\mathrm{X}-10$

A-3, D-1

E-4, Y-3

F-10

ZB-18

F-12

F-7, F-8

M-11

C

X-9

ZA-1, ZA-3, ZA-5

$\mathrm{Y}-3$

J-1 1, J-12, L-4, L-5, R-2, ZI-2

ZA-1, ZA-3, ZA-5

L-1

A-1

C-4

M-11

ZB-8
Daly, P. C.

Damato, C.

Dayton, R. W.

Dean, C. W.

Dickerson, R. F.

DiGiallonardo, S. I.

Draley, J. E.

Duran, J. B.

Dwight, A. E.

Elkington, W. E.

Epremian, Edward

Erickson, W. C.

Estill, W.
$\underline{\mathrm{D}}$

$\mathrm{Y}-2$

$\mathrm{X}-10$

E-3, ZC-1, ZC-3

$\mathrm{V}-8$

D-1

V-6

$\mathrm{J}-3, \mathrm{~J}-6, \mathrm{O}-2, \mathrm{X}-1, \mathrm{X}-3$

$\mathrm{N}-4$

A-1, J-1, T-1

$\underline{E}$

F-5

ZF-6, ZF-7, ZF-8, ZF-9

F-13

N-3

F

Fackelmann, J. M. A-3

Fedorov, G. B.

S-1, S-2, S-3

Ferguson, J. E.

N-5

Ferguson, M. R.

Ferris, L. M.

I-1

Fillnow, R. H.

Fisher, R. E.

K-2

$\mathrm{X}-2$

Foote, F. G.

N-4

Foster, F. J.

B-1, B-2, Y-5, Y-6

E-7

Frank, J. W.

C-3, O-1

G

Gens, T. A.

H-1, H-2, K-2, K-3

Goad, H. A.

L-2 


\begin{tabular}{|c|c|c|c|}
\hline Gomov, V. V. & $V-9$ & Klein, J. L. & $\mathrm{E}-2$ \\
\hline Gomozov, L. A. & $\mathrm{G}-3$ & Kobylkin, A. N. & F-7 \\
\hline \multirow[t]{2}{*}{ Gomozov, L. I. } & \multirow{2}{*}{$\begin{array}{l}\text { F-1, J-7, J-8, Q-1, T-4, } \\
\text { T-5, V-2, V-7, V-9 }\end{array}$} & Kochen, R. L. & $\mathrm{J}-9$ \\
\hline & & Kouts, H. J. C. & F-9 \\
\hline Greenberg, S. & $\mathrm{J}-3, \mathrm{~J}-5, \mathrm{O}-2, \mathrm{X}-1, \mathrm{X}-3$ & Kuznetsova, R. I. & $\mathrm{T}-7$ \\
\hline Greene, L. A. & E-6 & & \\
\hline Gruelich, F. A. & $\mathrm{N}-2$ & & \\
\hline Grigorovich, V. K. & F-7, F-8 & & $\underline{\mathrm{L}}$. \\
\hline \multirow[t]{4}{*}{ Gusev, V. N. } & \multirow[t]{2}{*}{$S-2, S-3$} & Larson, D. T. & L-3 \\
\hline & & Lehmann, J. & W-1 \\
\hline & . & Lillie, D. W. & $\mathrm{ZF}-1, \mathrm{ZF}-2, \mathrm{ZF}-3$ \\
\hline & $\underline{\mathrm{H}}$ & Lindgren, J. R. & $E-4, Y-3$ \\
\hline Haynes, W. B. & $\mathrm{C}-2$ & Lloyd, L. T. & A-1 \\
\hline Hays, D. D. & $\mathrm{P}-2$ & Lowenstein, $\mathrm{P}$. & $\mathrm{E}-2, \mathrm{ZB}-8$ \\
\hline Hendrie, J. M. & F-9 & Lorenz, F. R. & $\mathrm{C}-2$ \\
\hline Hoffman, K. C. & F-9 & Lundin, M. I. & $Y-1$ \\
\hline Hoge, K. G. & F-6 & Lustman, B. & $\mathrm{ZJ}-3$ \\
\hline Holtz, F. C. & $\mathrm{V}-1$ & & \\
\hline \multirow[t]{2}{*}{ Hurford, W. J. } & \multirow{2}{*}{\multicolumn{2}{|c|}{$\mathrm{K}-1$}} & \\
\hline & & & $\underline{\mathrm{M}}$ \\
\hline \multirow[t]{2}{*}{. } & \multirow{2}{*}{ 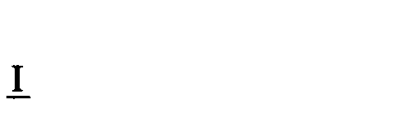 } & Macherey, R. E. & $C-3, E-4, Y-3$ \\
\hline & & Macki, J. M. & $\mathrm{J}-9$ \\
\hline \multirow{5}{*}{ Ivanov, O.S. } & \multirow{2}{*}{$\begin{array}{l}\text { F-2, F-7, F-8, G-3, J-7, } \\
\text { J-8, T-2, T-4, T-5, T-6, } \\
\text { V-2, V-3, V-4, V-7, V-9 }\end{array}$} & Magnani, N. J. & $\begin{array}{l}\text { M-6, M-8, M-9, M-10, } \\
\text { M-12 }\end{array}$ \\
\hline & & Makhova, V. A. & V-9 \\
\hline & . & McClure, J. J. & $\bar{Y}-4$ \\
\hline & \multirow{2}{*}{$\underline{\mathbf{J}}$} & McDougal, J. R. & E-6 \\
\hline & & McRickard, S. B. & $X-2$ \\
\hline \multirow{3}{*}{$\begin{array}{l}\text { Jackson, R. J. } \\
\text { Jaynes, G. E. } \\
\text { Jenks, G. H. }\end{array}$} & $\mathrm{F}-12$ & Miglionico, C. J. & M-6, M-8 \\
\hline & F-13 & Moak, D. P. & $A-3$ \\
\hline & $\mathrm{Q}-2$ & Mueller, M. H. & $\mathrm{T}-1$ \\
\hline \multirow[t]{2}{*}{ ' } & & & 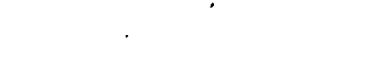 \\
\hline & $\underline{\mathbf{K}}$ & & $\underline{\mathbf{N}}$ \\
\hline Kass, $\mathrm{S}$. & $\mathrm{J}-2$ & Nevitt, M. V. & A-1 \\
\hline mann, A. R. & E-2 & & . \\
\hline Khomov, F. I. & S-1 & & \\
\hline Kishinevskii, V. B. & $\mathrm{J}-8, \mathrm{~V}-7$ & & $\underline{\mathrm{U}}$ \\
\hline Kittel, J. H. & $\begin{array}{l}\text { B-4, G-1, X-1, X-5, X-6, } \\
\text { X-8 }\end{array}$ & $\begin{array}{l}\text { Oakes, R. E. Jr. } \\
\text { Orman, S. }\end{array}$ & $\begin{array}{l}\mathrm{P}-4 \\
\mathrm{M}-5\end{array}$ \\
\hline
\end{tabular}


$\underline{\mathbf{P}}$

Paine, S. H.

Parry, S. J. S.

Parsick, R. J.

Pawel, R. E.

Paynton, W. C.

Peterson, C. A. W.

Petersen, G. F.

Phelps, J. P.

Porter, I. T.

Price, G. A.

$\begin{array}{ll} & \underline{\text { R }} \\ \text { Raetskii, V. M. } & \text { Q-1 } \\ \text { Reeves, C. A. Jr. } & \text { F-11 } \\ \text { Reich, M. } & \text { F-9 } \\ \text { Renzoni, R. } & \text { X-10 } \\ \text { Roebuck, A. H. } & \text { J-1, O-1 } \\ \text { Romero, H. } & \text { M-6, M-8, M-12, O-4 } \\ \text { Royce, E. B. } & \text { R-1 } \\ \text { Ruckman, J. C. } & \text { N-1 } \\ \text { Ruther, W. E. } & \text { J-3, O-2 }\end{array}$

Sallach, R. A. J-10

Sandstrom, D. J. . F-13

Saraceno, F. S. . X-10

Sawyer, H. F.

Schumar, J. F.

Seegmiller, R.

Simmons, J. W.

Simnad, M. T.

Smirnov, E. A.

Sokurskii, Yu N.

Steele, W. J.

Stein, C.
$\underline{\mathbf{S}}$

$$
\mathrm{X}-1, \mathrm{X}-5, \mathrm{X}-6
$$

$\mathrm{V}-1$

F-9

J-12, L-4, R-2

ZB-8

F-3, F-4, M-4, P-1, V-6

$\mathrm{J}-11, \mathrm{~J}-12, \mathrm{~L}-4$

F-9

N-1

F-9

E-2, ZB-8

E-1

F-13

ZH-1, ZH-2

$\mathrm{J}-4$

S-2, S-3

$\mathrm{X}-4$

M-4, P-1, V-6

P-5
Stephenson, L. L.

M-7

Stohr, J. A.

$\mathrm{X}-7$

Storhok, V. W.

D-1

Stewart, J. H. Jr.

I-1, I-2

I

Takahashi, $\mathrm{H}$.

F-9

Taub, J. M.

F-13

Terada, K.

L-2

Tevebaugh, A. D.

Thomas, D. E.

ZB-17, ZB-1 8

Tipton, C. R. Jr.

$\mathrm{X}-2$

ZC-1, ZC-3

Tragert, W. E.

$\mathrm{M}-1, \mathrm{M}-2$

Tretyakov, A. A.

$\mathrm{V}-7$

$\underline{\mathrm{V}}$

Vandervoort, R. R. F-3, F-4, F-5

Van Thyne, R. J.

$\mathrm{V}-1$

Virgilev, Yu S.

F-2, O-3, T-6, V-3, V-4, $\mathrm{V}-5$

W

Weiss, H. D.

A-2

White, J. F. .

ZF-5

Whitlow, G. A.

M-3

Wilson, T. B.

$\mathrm{X}-10$

Windsor, H. H.

F-9

Winslow, F. R.

F-10

$\underline{Y}$

Yakel, H. L.

W-2, ZI-3

$\underline{Z}$

Zavgorodnii, A. Ya Q-1

Zegler, S. T. 